\title{
Abordagem algébrica para seleção de clones ótimos em projetos genomas e metagenomas
}

\author{
Mauricio Egídio Cantão
}

\author{
PROGRAMA INTERUNIDADES EM BIOINFORMÁTICA \\ DA \\ UNIVERSIDADE DE SÃO PAULO
}

\author{
ÁREA DE CONCENTRAÇÃO: BIOINFORMÁTICA \\ ORIENTADORA: Prof ${ }^{\mathrm{a}}$. Dr ${ }^{\mathrm{a}}$. Eliana G. M. Lemos \\ CO-ORIENTADOR: Prof. Dr. João Eduardo Ferreira
}

São Paulo, 1 de Dezembro de 2009 
Dedico este trabalho aos meus pais, Nilse e Valdir, a meus irmãos, Adriano e Luciano, e à minha noiva Nátalie, pelo amor, carinho, confiança e aos esforços dispensados para a minha formação. 


\section{Agradecimentos}

Primeiramente, agradeço a Deus por ter me dado a oportunidade de estar no mundo.

Aos meus pais, Valdir Egídio Cantão e Nilse de Jesus Perseguin Cantão, e à minha família, agradeço todo o amor, carinho, compreensão e respeito.

Agradeço a meus orientadores Prof ${ }^{a}$. Dra . Eliana Gertrude de Macedo Lemos e Prof. Dr. João Eduardo Ferreira que, além de me orientar cientificamente, me deram ensinamentos que foram úteis no meu crescimento pessoal e profissional. A vocês serei eternamente grato.

Aos meus amigos do Laboratório (LBMP) em especial ao Rodrigo Matheus Pereira e Luciano Takeshi Kishi, pela ajuda que me deram durante todo o doutorado, principalmente pela disposição em me explicar incansavelmente às dúvidas biológicas que surgiram durante o desenvolvimento da tese. Sem esquecer que muitas dessas discussões ocorreram na escada do laboratório, comendo pizza ou lanche durante o turno noturno. Aos amigos Douglas Paixão, Érico Silveira e ao Tehuni González que ficavam durante o terceiro turno no Laboratório.

Agradeço também ao pessoal do Laboratório de Banco de Dados do IME-USP, em especial ao Luciano Araújo, que considero uma pessoa extraordinária como pessoa, profissional e amigo.

Aos companheiros de república Maurílio Garcia, André Pádua Durante, Eric Motoiama, pela amizade e convivência.

Enfim, a todos aqueles que de forma direta ou indireta colaboraram para a realização deste trabalho.

Muito obrigado! 


\section{Resumo}

Devido à grande diversidade de microrganismos desconhecidos no meio ambiente, $99 \%$ deles não podem ser cultivados nos meios de cultura tradicionais dos laboratórios. Para isso, projetos metagenômicos são propostos para estudar comunidades microbianas presentes no meio ambiente, a partir de técnicas moleculares, em especial o seqüenciamento. Dessa forma, para os próximos anos é esperado um acúmulo de seqüências produzidas por esses projetos. As sequiências produzidas pelos projetos genomas e metagenomas apresentam vários desafios para o tratamento, armazenamento e análise, como exemplo: a busca de clones contendo genes de interesse.

Este trabalho apresenta uma abordagem algébrica que define e gerencia de forma dinâmica as regras para a seleção de clones em bibliotecas genômicas e metagenômicas, que se baseiam em álgebra de processos. Além disso, uma interface web foi desenvolvida para permitir que os pesquisadores criem e executem facilmente suas próprias regras de seleção de clones em bancos de dados de seqüências genômicas e metagenômicas. Este software foi testado em bibliotecas genômicas e metagenômicas e foi capaz de selecionar clones contendo genes de interesse. 


\begin{abstract}
Due to the wide diversity of unknown organisms in the environment, $99 \%$ of them cannot be grown in traditional culture medium in laboratories. Therefore, metagenomics projects are proposed to study microbial communities present in the environment, from molecular techniques, especially the sequencing. Thereby, for the coming years it is expected an accumulation of sequences produced by these projects. Thus, the sequences produced by genomics and metagenomics projects present several challenges for the treatment, storing and analysis such as: the search for clones containing genes of interest.

This work presents an algebraic approach that defines it dynamically and manages the rules of the selection of clones in genomic and metagenomic libraries, which are based on process algebra. Furthermore, a web interface was developed to allow researchers to easily create and execute their own rules to select clones in genomic and metagenomic sequence database. This software was tested in genomics and metagenomics libraries and it was able to select clones containing genes of interest.
\end{abstract}




\section{Índice}

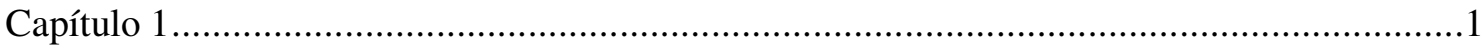

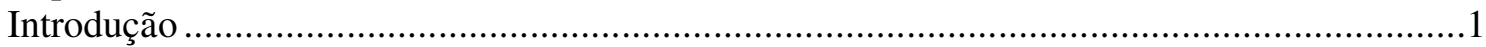

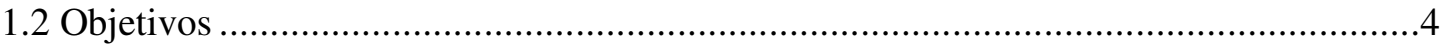

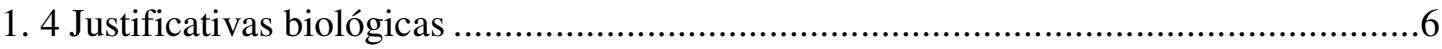

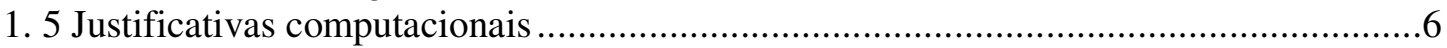

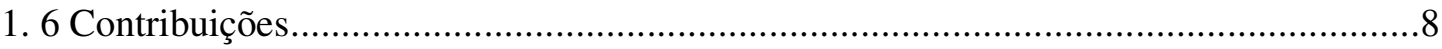

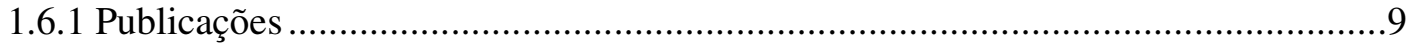

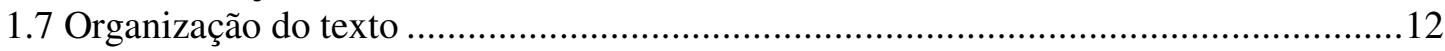

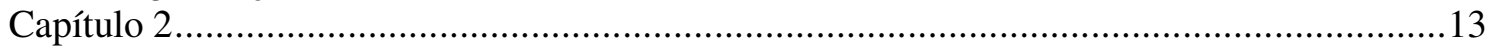

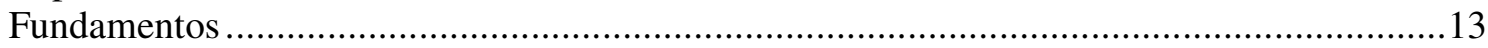

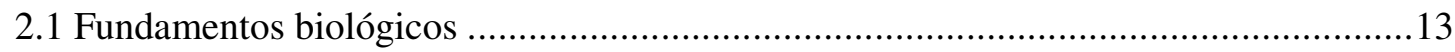

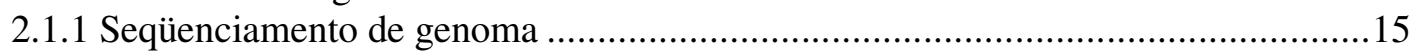

2.1.2 Método de Sanger ............................................................................................16

2.1.3 Seqüenciamento de genoma pela técnica de shotgun ..........................................17

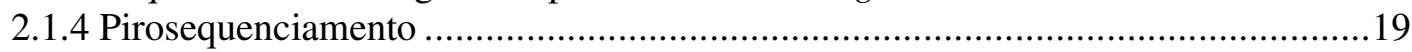

2.1.5 Plataforma de seqüenciamento Solid e Solexa .....................................................2

2.1.6 Técnica de microarranjo de DNA ..................................................................21

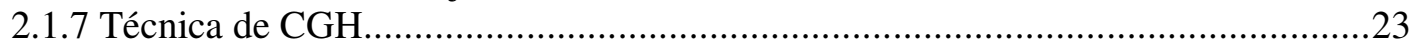

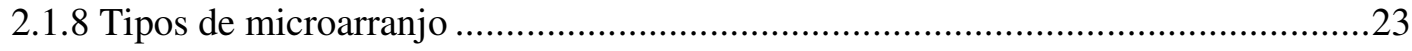

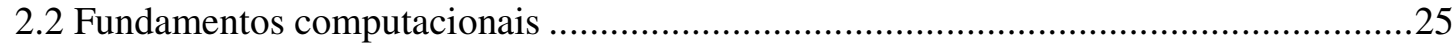

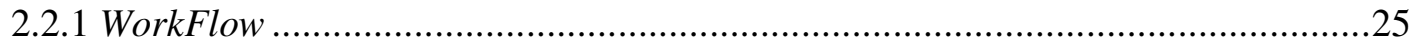

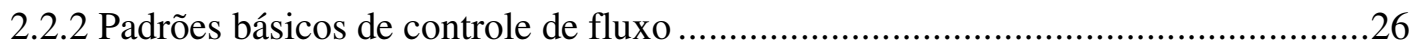

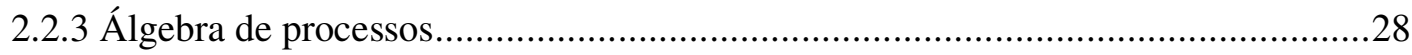

2.2.4 NPDL - Linguagem para definição de plano de navegação ……………………......29

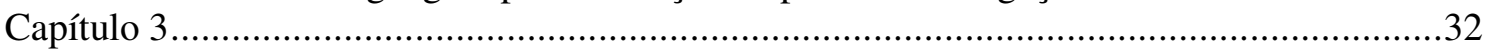

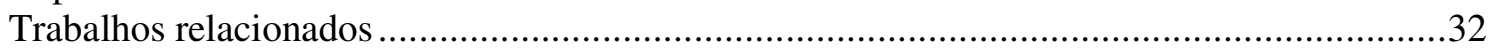

3.1 Microarranjos compostos por clones de shotgun …………………………................33

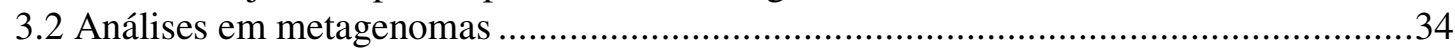

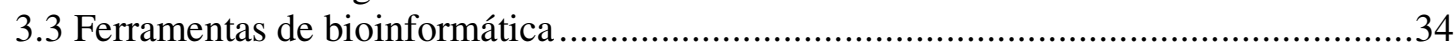

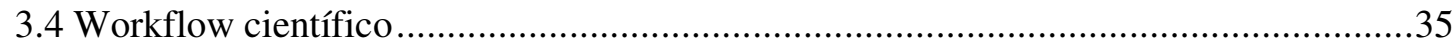

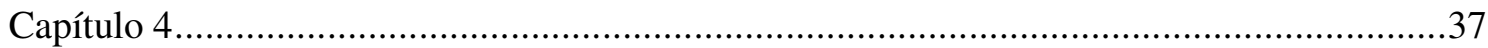

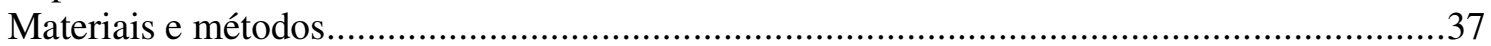

4.1 Regras de seleção de clones ................................................................................38

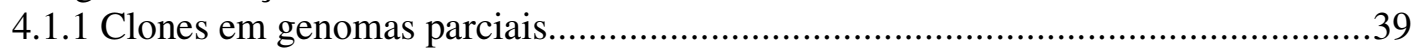

4.1.1.1 Clones localizados nos mesmos contigs, ou contigs separados........................40

4.1.1.2 Clones localizados nas sequiências dos contigs e singlets ................................42

4.1.1.3 Clones localizados como singlets...............................................................43

4.1.2 Clones em genomas completos e metagenômicos ....................................................43

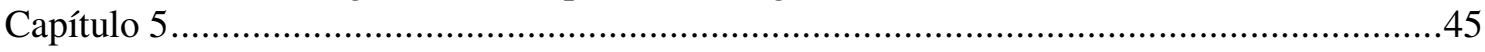

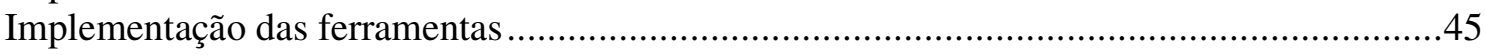

5.1 Gerenciamento do fluxo do sistema via código de programação.....................................45

5.2 Gerenciamento do fluxo do sistema por linguagem algébrica ………………..................4

5.3 Definição das regras e ações que compõem o processo de seleção dos clones no OCI 2

5.3.1 Interpretação das regras e mapeamento em álgebra de processos .............................50

5.4 Modelagem do banco de dados do OCI 2 ............................................................5 


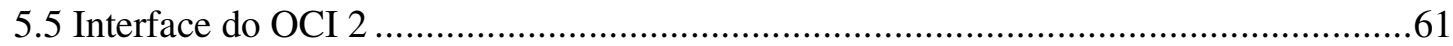

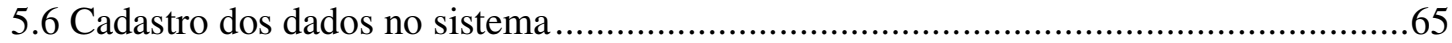

5.6.1 Formatação dos arquivos em genomas completos............................................65

5.6.2 Formatação dos arquivos em genomas parciais.............................................68

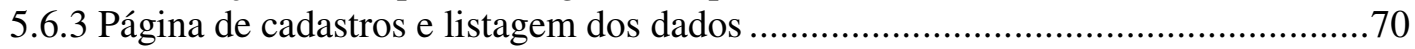

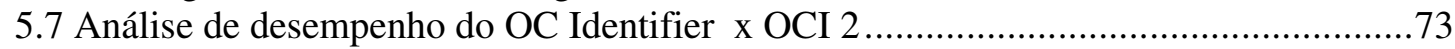

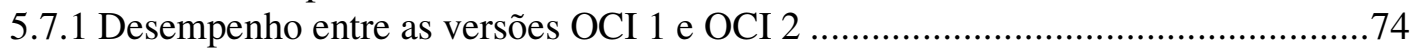

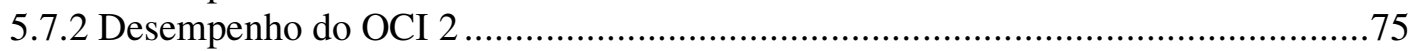

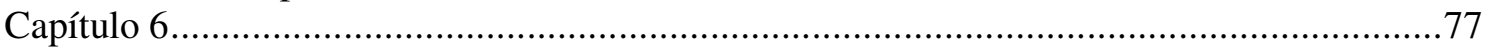

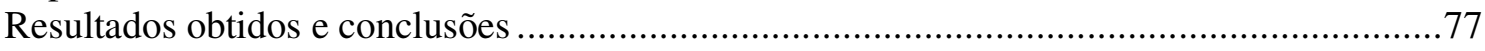

6.1 Resultados da seleção de clones ótimos com OC Identifier tool ..................................77

6.2 Resultados da seleção de clones pelo OCI 2 aplicado na segunda montagem parcial do

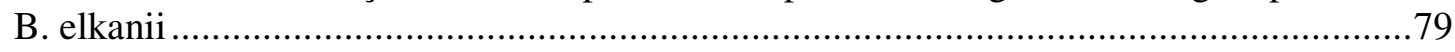

6.3 Resultados da seleção de clones pelo OCI 2 aplicado no genoma completo de X. citri 81

6.4 Resultados da seleção de clones pelo OCI 2 aplicado em projeto metagenômico..........83

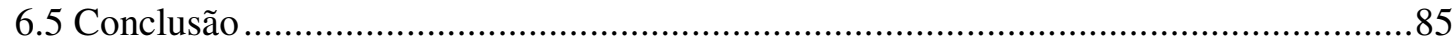

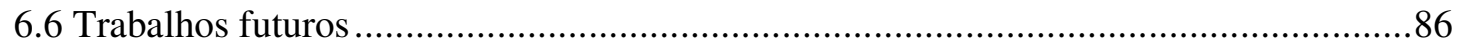

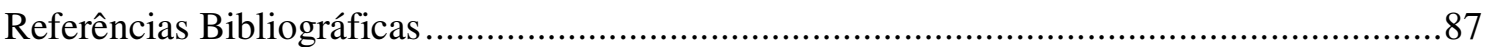




\section{Índice de Figuras}

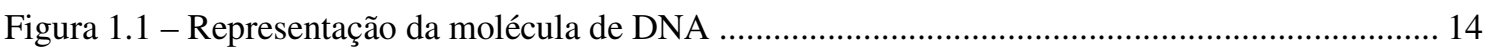

Figura 1.2 - Representação da molécula de RNA.............................................................................. 14

Figura 2 - Processo de transcrição do DNA em RNAm para a síntese de proteína................................ 15

Figura 3.1 - Amplificação dos fragmentos de DNA interrompidos por um ddNTP............................. 17

Figura 3.2 - Eletroferograma onde cada pico representa uma base lida do DNA................................ 17

Figura 4 - No seqüenciamento de organismos com genomas menores de $3 \mathrm{Mb}$ e/ou baixo número de gaps e/ou alto número de regiões repetitivas, foi feita a cobertura do genoma 8 vezes pela técnica de Sanger para alcançar a abordagem de melhor custo-benefício. Aos organismos maiores de $3 \mathrm{Mb}$, e/ou muitos gaps nas seqüências, e/ou muitas regiões com paradas bruscas durante o seqüenciamento, foi usado um seqüenciamento inicial cobrindo 5 vezes o genoma pela técnica de Sanger, seguidos de 2 corridas usando o pirosequenciamento para alcançar a abordagem de melhor custo-benefício..................................................................................... 20

Figura 5 - Esquema ilustrativo dos procedimentos da técnica de microarranjo de DNA ..................... 22

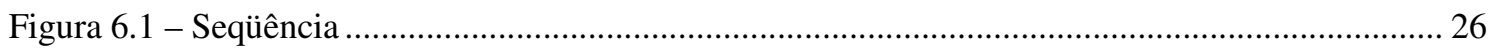

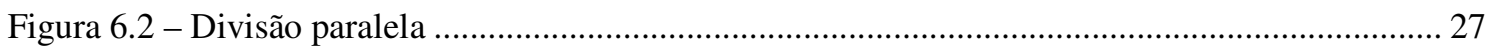

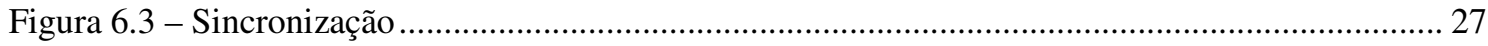

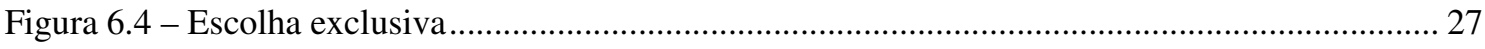

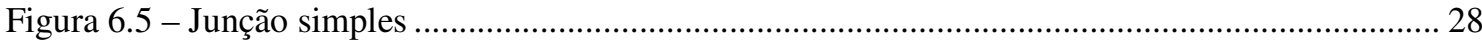

Figura 7.1 - Esquema das posições das ORFs e dos clones dentro dos contigs. No "Contig 1" e "Contig 2", são duas ORFs inicialmente identificadas. Mesmo com um gap entre os dois contigs, identificou-se que a "ORF 2" do "Contig 2" é a mesma e continuação da "ORF 2" do "Contig 1". O clone ótimo que seleciona a "ORF 2" é o clone "D", enquanto que o clone ótimo que seleciona a "ORF 1" é o Clone "A"..

Figura 7.2 - O clone B representa a "ORF 8", sendo considerado como ótimo por conter apenas 1 ORF. Nesse exemplo, a seqüência amplificada pelo óligo forward do clone está localizada internamente ao "Contig 19”, enquanto que a sequiência reversa (B') aparece como Singlet .... 42

Figura 7.3 - As sequiências desse clone estão identificadas como singlets, pois estão fora dos contigs e possuem a mesma ORF identificada nas duas seqüências 43

Figura 7.4 - Clones dispostos na seqüência final do genoma cromossomal. 43

Figura 8 - Representa um genoma completo e contém as sequiências das ORFs de 1 a 3, os clones são identificados pelas letras $A$ a $H$, e as seqüências dos cosmídeos identificadas pela letra $C$, seguida de um número, por exemplo $C 1, C 2$. Os clones e cosmídeos são formados pelas 
seqüências forward e reverse, sendo que a seqüência reverse é identificada por aspas simples após seus nomes, exemplo, $A^{\prime}, D^{\prime}, C 3^{\prime}$. Nem sempre as duas sequiências do clone estão presentes na montagem, como é o caso dos clones $B, H$ e $I$. 52

Figura 9 - Representa um fragmento de um genoma com duas ORFs, uma seqüência de "rRNA 5S" e 8 clones identificados pelas letras "A" a "H". O clone "B" encontra-se interno à "ORF 4", enquanto que o clone "F" está localizado externamente à "ORF 5". O clone "E" representa a "ORF 5" e contém 7 bases da seqüência do "rRNA 5S" na seqüência no sentido forward........ 54

Figura 10 - Representa um fragmento de um genoma com 2 ORFs, na região promotora da "ORF 12" e 6 clones identificados pelas letras $A$ a $F$. O clone $A$ cobre a "ORF 11" em 450 bases, enquanto que o clone $B$ cobre a mesma ORF com 800 bases. O clone $D$ representa a "ORF 12" por completo e inicia a 19 bases antes de sua região promotora, enquanto que o clone $E$ representa a "ORF 12", cobrindo 900 bases da mesma. 57

Figura 11 - Modelo conceitual/lógico do banco de dados da ferramenta OCI 2 para genomas completos, parciais e metagenômicos 59

Figura 12 - Modelo fisico do banco de dados da ferramenta $O C I 2$ para genomas completos, parciais e metagenômicos.

Figura 13 - Interface da ferramenta para projeto de genoma completo de procarioto. Nessa interface, o usuário seleciona quais as atividades que farão parte da regra e define seus valores. Definida as regras, a ferramenta gera a expressão algébrica que representa fielmente o processo de seleção61

Figura 14 - Página responsável pela execução, cancelamento, edição e exclusão das regras elaboradas

62

Figura 15 - Interface da ferramenta no projeto de genoma parcial. Essa interface apresenta a adição da nova informação 'Clone Localization' ao processo de seleção de clones.....

Figura 16 - Visualização do número de clones selecionados por cada regra e os clones selecionados após a finalização do processo 64

Figura 17 - Após a execução dos processos, é possível visualizar, cancelar ou fazer download dos resultados

Figura 18.1 - Exemplo do arquivo de cadastro das ORFs no formato protein table. Cada campo no arquivo é separado pelo delimitador $t a b$ 66

Figura 18.2 - Exemplo do arquivo de cadastro dos clones que compõem o genoma ............................. 66

Figura 18.3 - Exemplo do arquivo de cadastro das regiões promotoras ou ITS ................................... 67

Figura 18.4 - Exemplo do arquivo de cadastro das categorias funcionais............................................ 67

Figura 18.5 - Exemplo de arquivo de cadastro das categorias funcionais para cada ORF no genoma. 68

Figura 19.1 - Exemplo do arquivo de cadastro das ORFs presentes no genoma ................................... 68

Figura 19.2 - Exemplo do arquivo de cadastro das ORFs nas seqüências dos contigs......................... 69 
Figura 19.3 - Exemplo do arquivo de cadastro das ORFs nas seqüências dos clones ........................... 69

Figura 19.4 - Exemplo do arquivo de cadastro dos clones que compõem o genoma ............................ 70

Figura 19.5 - Exemplo do arquivo de cadastro da região promotora ou ITS nas sequiências do genoma 70

Figura 20 - Página de cadastro dos tipos de seqüências genômicas .................................................... 71

Figura 21 - Página que realiza o upload dos arquivos para cadastramento dos dados primários e

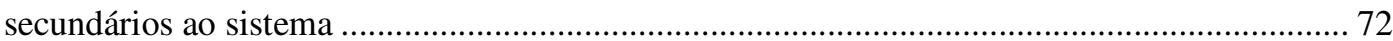

Figura 22 - Lista das seqüências cadastradas no sistema...................................................................... 73

Figura 23 - Tempo de processamento em relação ao número de clones presentes na consulta............. 74

Figura 24 - Evolução no tempo de processamento de seleção dos clones no genoma completo de $X$.

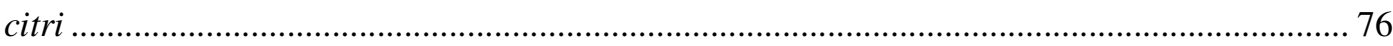




\section{Índice de Tabelas}

Tabela 1 - Número de clones selecionados após a execução do processo Select_CC_S ...................... 79

Tabela 2 - Número de clones selecionados após a execução do processo Select_CC_D ...................... 80

Tabela 3 - Número de clones selecionados após a execução do processo Select_CS............................ 80

Tabela 4 - Número de clones selecionados após a execução do processo Select_SS ............................ 80

Tabela 5 - Número de clones selecionados após a execução de cada regra no genoma completo da $X$.

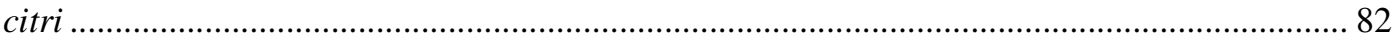

Tabela 6 - Códigos de identificação e funções das ORFs identificadas e anotadas do Cosmídeo B7P37 84

Tabela 7 - Número de clones selecionados após a execução de cada regra do processo Select_ORF_3

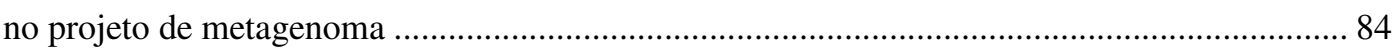




\section{Siglas}

ACP

AOT

BAC

CCS

$\mathrm{CGH}$

COG

CSP

CT

DCT

DDR

DNA

DNAc

ddNTP

dNTP

DOC

DOW

EST

GB

$\mathrm{GHz}$

GO

HD

PRI

$\mathrm{Kbp}$

ITS

LBMP

LCC

MAPA

$\mathrm{MHz}$

NCBI
Algebra of Communicating Processes

AnalysisOverlapTarget

Bacterial Artificial Chromosome

Calculus of Communicating Systems

Comparative Genomic Hybridization

Clusters of Orthologous Groups

Communicating Sequential Processes

CoverageTarget

DistanceCloneTarget

Double Data Rate

Deoxyribonucleic Acid ou Ácido Desoxirribonucléico

Ácido Desoxirribonucléico complementar

Didesoxinucleotídeo

Desoxirribonucleotídeo

DisplayOptimalClones

Download

Expressed Sequence Tag

GigaByte

Giga Hertz

Go on

Hard Disk

Print

Kilo base pairs

Internal Transcribed Spacer

Laboratório de Bioquímica de Microrganismos e Plantas

LocalizacaoCloneContig

Ministério da Agricultura, Pecuária e Abastecimento

Mega Hertz

National Center for Biotechnology Information 


\begin{tabular}{|c|c|}
\hline NOS & NumOrfSeq \\
\hline NPDL & Navigation Plan Definition Language \\
\hline $\mathrm{OC}$ & Optimal Clone \\
\hline OCI & Optimal Clone Identifier \\
\hline $\mathrm{OH}$ & Hidroxila \\
\hline ORF & Open Reading Frame \\
\hline PCR & Polymerase Chain Reaction \\
\hline PCT & PositionCloneTarget \\
\hline $\mathrm{PO}$ & PosicaoOrf \\
\hline PPi & Pirofosfato \\
\hline PR & PromoterRegion \\
\hline PTT & Protein Table \\
\hline RAM & Random Access Memory \\
\hline RDM & Rhizobia Defined Medium \\
\hline RNA & Ribonucleic acid ou Ácido Ribonucléico \\
\hline RNAm & Ácido Ribonucléico mensageiro \\
\hline RNAt & Ácido Ribonucléico transportador \\
\hline RNAr & Ácido Ribonucléico ribossomal \\
\hline RPM & Rotação Por Minuto \\
\hline SATA & Serial Advanced Technology Attachment \\
\hline SABIA & System for Automated Bacterial Integrated Annotation \\
\hline SCBI & SelectClonesById \\
\hline SCBT & SelectClonesByTarget \\
\hline SO & SeqOrf \\
\hline SQL & Structured Query Language \\
\hline TSV & Tab Separated Values \\
\hline TY & Triptone-Yeast \\
\hline WfMC & Workflow Management Coalition \\
\hline WFMS & Workflow Management System \\
\hline YAC & Yeast Artificial Chromosome \\
\hline
\end{tabular}




\section{Capítulo 1}

\section{Introdução}

Nas seqüências de DNA dos organismos, algumas regiões contêm informações para a síntese de proteínas. Nessas regiões, as sequiências de DNA, que são transcritas em RNAm (RNA mensageiro) e sintetizadas em proteínas, são chamadas de genes (Voet, Voet e Pratt, 2000). Identificar os genes que compõem o organismo e saber quando estão sendo expressos (transcritos em RNAm) é fundamental para a compreensão dos mecanismos envolvidos nos processos celulares em escala molecular.

Uma forma experimental de análise do perfil de expressão gênica em organismos é a técnica de microarranjos de DNA. Essa técnica consiste de análise em larga escala do nível de expressão gênica, usando como base o princípio da hibridização (processo de junção das fitas complementares do DNA). Além de análises de expressão gênica, essa técnica vem sendo utilizada na comparação de dois ou mais genomas por meio da hibridização, conhecido como CGH (do inglês Comparative Genomic Hybridization), como também na identificação de polimorfismos que podem ser úteis nos diagnósticos e prognósticos de doenças genéticas (Pinkel e Albertson, 2005).

Para o uso eficiente da tecnologia de microarranjos de DNA é importante a presença de seqüências de genes conhecidos na lâmina. Uma maneira de obter essas seqüências gênicas é por meio de genomas completamente seqüenciados. Com o genoma seqüenciado e anotado são sintetizados óligos, ou sondas de DNA, específicos para comporem microarranjos (Hauser et al., 2006). Porém, a síntese de milhares de sondas para representar os genes do genoma tem custo elevado, pois o desenho dos óligos e suas sínteses consomem tempo e recursos

humanos. Além disso, periodicamente os oligonucleotídeos utilizados nos experimentos necessitam ser sintetizados.

Uma alternativa às sínteses individuais de óligos para compor um microarranjo são os chips de DNA. Os chips são lâminas que contêm sondas dos genes do genoma pré-definidas e vendidas por empresas específicas. Porém, o uso do chip de DNA limita-se a um experimento por lâmina. Desse modo, para cada análise em microarranjo, uma nova lâmina deve ser 
adquirida. Além disso, nem todos os genomas possuem chips com os seus genes prontos para comercialização.

Outra forma de estudo dos genes com o uso de microarranjos é o uso de lâminas compostas por fragmentos de sequiências de DNA, obtidas por meio de bibliotecas genômicas, utilizando a metodologia de shotgun (Fleischmann et al., 1995). Nessa abordagem, as seqüências dos clones são impressas nas lâminas antes de serem seqüenciadas. Desse modo, não se sabe previamente quais são e quantos são os genes presentes em cada clone. Nessa metodologia, os RNAm transcritos nas células, sob diferentes condições experimentais, são extraídos e hibridizados nas sequiências dos clones presentes no microarranjo. Pelo fato de muitas seqüências conterem mais de um gene, análises adicionais são necessárias para a confirmação dos genes expressos. As seqüências dos clones que hibridizaram de forma diferenciada em cada experimento são seqüenciadas e terão seus genes posteriormente identificados. Com os genes identificados, óligos específicos para cada gene são desenhados e submetidos a análises de expressão gênica, pelo método de PCR (do inglês Polymerase Chain Reaction) quantitativo em tempo real (Scott et al., 2006).

Uma abordagem alternativa às sínteses de oligonucleotídeos específicos nos estudos dos genes, com o uso de microarranjos de DNA, é a seleção dos clones de bibliotecas de DNA genômico contendo genes únicos. $\mathrm{O}$ uso dos clones com genes únicos possibilita a composição de microarranjo de DNA no qual se sabe, a priori, quais serão os genes presentes na lâmina. A seleção dos clones pode ser aplicada tanto em genomas procariotos, quanto eucariotos, estando eles completos ou parciais, assim como em projetos de metagenomas.

Em genomas parciais, os clones são identificados durante as fases de seqüenciamento e selecionados entre milhares de seqüências geradas durante o projeto. Nos genomas completos, as análises são baseadas em todos os clones usados na montagem final. Entre todos os clones do genoma, aqueles selecionados com genes únicos são denominados clones ótimos (Cantão et al., 2007), pois eles contêm as sequiências dos genes de interesse usados como abordagem alternativa às sínteses dos oligonucleotídeos.

Para tornar possível o processo de seleção dos clones com genes únicos, este trabalho apresenta como principal contribuição a elaboração das regras de identificação e seleção dos clones, não apenas para genomas procariotos parcialmente ou completamente seqüenciados, como também para projetos de metagenomas. Todas as regras de seleção são mapeadas em expressões algébricas por meio da álgebra de processos. Tal abordagem diferencia-se dos 
trabalhos relacionados, pois permite maior precisão na definição e execução das regras de seleção, além da geração automática do código computacional. 


\subsection{Objetivos}

O trabalho tem como principal objetivo criar as regras de seleção de clones ótimos e mapeá-las em álgebra de processos para que sejam usadas não apenas em genomas procariotos parcialmente ou completamente seqüenciados, como também para projetos de metagenomas sem a grande e indesejada necessidade de manutenção de código-fonte computacional, muito comum em ferramentas de bioinformática.

Além da elaboração das regras em álgebra de processos, o trabalho também tem como objetivo o desenvolvimento de uma interface web para auxiliar aos usuários no processo de criação das regras de seleção de clones ótimos. 


\subsection{Motivação}

A motivação para a realização deste trabalho surgiu da necessidade de mapear todas as regras de seleção de clones ótimos em álgebra de processos e sua implementação em uma ferramenta que fosse capaz de identificar e selecionar clones de interesse entre milhares de seqüências de DNA, produzidas nos projetos genomas. Desse modo, o uso dos clones selecionados pelas regras como abordagem alternativa às sínteses de oligonucleotídeos nos estudos com microarranjo de DNA, diminui a demanda de recursos humanos e materiais nas análises com microarranjos, concomitante à montagem de genomas. 


\section{4 Justificativas biológicas}

No seqüenciamento de genoma, a fase final de montagem pela técnica de shotgun requer grandes esforços e recursos financeiros, tendo em vista o grande número de repetições na seqüência do DNA e diversas regiões do genoma ainda não seqüenciado. Tais problemas conduzem à necessidade de se aplicar diferentes estratégias a fim de alcançar o completo seqüenciamento do genoma (Roach et al., 2000). Uma vez o genoma completo, é possível iniciar o processo de síntese de oligonucleotídeos específicos para cada gene no genoma ou sondas de DNA, como forma de estudos funcionais dos genes.

Entre as vantagens do uso da abordagem de seqüências de shotgun com genes, destacase: a) a alternativa - síntese de oligonucleotídeos; b) o início das análises realizadas durante a fase de seqüenciamento, sem a necessidade de finalizar o genoma; c) o uso concomitante dos clones de shotgun em projetos com diferentes finalidades: montagem do genoma, composição de microarranjo de DNA para análises de expressão gênica e comparação de genomas por CGH; d) amplificação dos fragmentos gênicos sempre que necessários, ao contrário dos oligonucleotídeos que, periodicamente precisam ser sintetizados; e) definição de estratégias para interrupção do seqüenciamento.

Desse modo, é possível desenvolve diferentes projetos com o mesmo conjunto inicial de clones e adicionalmente possibilita a diminuição dos custos com a síntese de óligos e recursos humanos.

\section{5 Justificativas computacionais}

Em projetos genomas, milhares de sequiências de DNA são produzidas durante as fases de seqüenciamento. Sendo assim, o uso de ferramentas computacionais torna-se crucial no auxílio às análises de milhares de dados gerados pelos seqüenciadores automáticos. Porém, softwares desenvolvidos para lidar com informações genômicas necessitam de atualizações freqüentes, a fim de adaptarem-se as recentes tecnologias e, também, a diferentes estratégias adotadas para cada projeto.

Com o propósito de assegurar precisão nos processos de alterações e execuções das regras realizadas pelos usuários, assim com na expansão de seleção de clones para novos projetos e genomas, o uso de uma abordagem algébrica proporciona a geração automática do 
código que controla os fluxos do sistema e garante sua correta execução. A álgebra de processos apresenta-se como uma linguagem com alto poder de expressividade, possui grande flexibilidade e consistência para representar e mapear sistemas que necessitam de alterações freqüentes em suas regras (Fokkink, 2000). 


\section{6 Contribuições}

A primeira versão das regras de seleção de clones implementado na ferramenta $O C$ Identifier (Cantão et al., 2007), foi inicialmente desenvolvida para atender às necessidades encontradas nos projetos biológicos do Laboratório de Bioquímica de Microrganismos e Plantas (LBMP - UNESP/Jaboticabal). Para tanto, com a ênfase voltada aos resultados da seleção dos clones, as regras foram inicialmente desenvolvidas para satisfazer aos parâmetros de buscas pré-definidos ao projeto, e o mesmo, implementado no código fonte da aplicação. Uma vez que a preocupação inicial foi de validar os experimentos biológicos, o uso de abordagens computacionais avançadas, por exemplo, a álgebra de processos na implementação das regras à ferramenta demandaria maior tempo para seu completo desenvolvimento. Desse modo, uma implementação com uma abordagem computacional tradicional foi realizada na primeira versão da ferramenta.

Com a validação dos resultados obtidos nos experimentos biológicos, o enfoque do trabalho voltou-se para a ampliação e aperfeiçoamento das regras de seleção de clones a diferentes projetos e organismos. Para isso, foi adotada a álgebra de processos como arcabouço formal no controle dos fluxos do sistema, e as regras passaram a ser mapeadas em expressões algébricas, o que proporcionou maior flexibilidade e eficiência no processo de seleção de clones implementado no OCI 2 (Cantão et al., 2009).

Como contribuições, a ferramenta $O C$ Identifier selecionou clones contendo genes únicos das bibliotecas genômicas da bactéria Bradyrhizobium elkanii Semia 587 para a confecção de um microarranjo de DNA, usados nos estudos de expressão gênica por Marcondes et al, (2008) em diferentes fases de crescimento da bactéria e por Pereira (2007) na comparação de genomas pela técnica de CGH. As primeiras análises de seleção foram realizadas na bactéria $B$. elkanii devido à sua importância na composição de inoculantes comerciais para a cultura de soja e, também, aos resultados na produtividade da agricultura do Brasil (MAPA, 2006). 


\subsubsection{Publicações}

Este trabalho gerou publicações relacionadas à ferramenta de automação no processo de seleção de clones e nos resultados das análises dos clones selecionados.

\section{Artigos}

\section{Periódico}

1. Cantão, M.E., Ferreira, J.E., Lemos, E.G.M. (2007). Optimal clone identifier for genomic shotgun libraries: 'OC Identifier tool'. Genet Mol Res, 6: 743-55.

\section{Publicados em anais de eventos}

1. Cantão, M.E., Araújo, L.V., Lemos, E.G.M., Ferreira, J. E. (2009). Optimal Clone Identifier based on Dynamic Rules and Process Algebra. In: International Conference on Bioinformatics, Computational Biology, Genomics and Chemoinformatics. International Society for Research in Science and Technology, p. 92-99.

2. Marcondes, J, Cantão, M.E., Alves, L.M.C., Lemos, E.G.M. (2007). Trasncriptional profile of Bradyrhizobium elkanii Semia 587 in symbiosis with soybean (Glycine max L. Merril) analyzed by DNA microarray. In: 15th International Congress on Nitrogen Fixation \& 12th International Conference of the African Association for Biological Nitrogen Fixation, Cape Town - África do Sul. BNF Applications for Poverty Alleviation.

\section{Aceito para publicação em anais de eventos}

1. Cantão, M.E., Araújo, L.V., Lemos, E.G.M., Ferreira, J. E. (2010). Algebraic approach to optimal clones selection applied in metagenomic projects. In: ACM International Symposium on Biocomputing, Kerala, India; 


\section{Submetido para Periódico}

1. Marcondes, J., Cantão, M.E., Alves, L.M.C., Lemos, E.G.M. Transcriptional Profiling of Bradyrhizoium elkanii in Defined and Complex Media Analyzed by DNA Microarray. Submetido para: Journal of Molecular Microbiology and Biotechnology.

\section{Capítulo de livro publicado}

1. Marcondes, J., Cantão, M.E., Alves, L.M.C., Lemos, E.G.M. (2008). Transcriptional profile of Bradyrhizobium elkanii Semia 587 in symbiosis with soybean (Glycine max L. Merril) analyzed by DNA microarray. Current Plant Science and Biotechnology in Agriculture. Springer, 42: 299-300.

\section{Apresentação oral de trabalho em congresso}

1. Cantão, M.E., Araújo, L.V., Lemos, E.G.M., Ferreira, J. E. (2009). Optimal Clone Identifier based on Dynamic Rules and Process Algebra. In: International Conference on Bioinformatics, Computational Biology, Genomics and Chemoinformatics, Orlando, FL, USA.

2. Cantão, M.E., Ferreira, J.E., Lemos, E.G.M. (2006). Optimal Clones Identifier for Genomic Shotgun Libraries: 'OC Identifier tool'. In: ISMB 2006 and 2nd Annual AB3C Conference: X-meeting, Fortaleza, CE.

\section{Resumos publicados em anais de eventos}

1. Marcondes, J., Cantão, M.E., Kishi, L.T., Alves, L.M.C., Lemos, E.G.M. (2009). Advance in Structural, Comparative, and Functional Analysis of Bradyrhizobium elkanii In: 16th International Congress on Nitrogen Fixation, Montana, USA. 
2. Cantão, M.E., Lemos, E.G.M., Ferreira, J.E. (2007). The use of OC identifier tool selecting optimal clones in finished genomes as an alternative to synthesis of primers for DNA Microarray analysis In: Brazilian Symposium on Bioinformatics 2007 and International Workshop on Genomic Databases (IWGD'07), Angra dos Reis, RJ.

3. Pereira, R.M., Cantão, M.E., Alves, L.M.C., Lemos, E.G.M. (2007) Comparative Genomic Hybridization between Bradyrhizobium elkanii and Sinorhizobium meliloti using DNA microarrays In: XXIII Reunión de la Asociación Latinoamericana de Rizobiología, Córdoba, Argentina.

4. Cantão, M.E., Pereira, R.M., Ferreira, J.E., Lemos, E.G.M. (2006). In silico comparison between Bradyrhizobium japonicum and Bradyrhizobium elkanii Semia 587 genomes. In: GDEST - Global Dialogues on Emerging Science and Technology, Petrópolis, RJ.

5. Sader, A.P., Cantão, M.E., Lemos, E.G.M., Carrilho, E. (2006). MultiDimensional Proteomic Analysis of Bradyrhizobium elkanii In: XXXV Reunião Anual da $S B B q$, Águas de Lindóia, SP.

6. Cantão, M.E., Ferreira, J.E., Lemos, E.G.M. (2005). Algorithm of selection of clones containing unique genes in partial genome for analyses in Microarray In: International Workshop on Genomic Databases (IWGD'05), Rio de Janeiro, RJ. 


\subsection{Organização do texto}

Este trabalho está organizado em 6 capítulos, como descrito a seguir:

Capítulo 1 - Introdução com objetivo, motivação, justificativas e contribuições.

Capítulo 2 - Fundamentos biológicos e computacionais necessários para a compreensão do trabalho;

Capítulo 3 - Trabalhos relacionados;

Capítulo 4 - Materiais e Métodos com a descrição das regras de seleção no projeto;

Capítulo 5 - Implementação das ferramentas, apresentação do ambiente de seleção de clones e mapeamento das regras em expressões da álgebra de processos;

Capítulo 6 - Resultados, conclusões e trabalhos futuros. 


\section{Capítulo 2}

\section{Fundamentos}

Nesta seção serão apresentados os fundamentos básicos biológicos e computacionais que estão diretamente relacionados à compreensão do projeto e para o desenvolvimento da ferramenta de análise de clones. Nesse sentido, os conceitos biológicos abrangem o seqüienciamento de DNA e a técnica de microarranjo, os quais são aplicados nas análises de expressão gênicas e nas comparações de genomas por hibridização. Nos fundamentos computacionais, serão abordados os conceitos de workflow (Hollinsworth, 1995), álgebra de processos e NPDL (do inglês Language Navigation Plan Definition Language) (Braghetto et al., 2006).

\subsection{Fundamentos biológicos}

O DNA ou ácido desoxirribonucléico é um tipo de ácido nucléico encontrado dentro das células dos organismos. É uma cadeia de polinucleotídeos, composto por quatro tipos diferentes de nucleotídeos, sendo eles: adenina (A), citosina (C), timina (T) e guanina (G). Cada nucleotídeo é composto por três partes, sendo elas: um açúcar, denominado desoxirribose, um grupo fosfato e uma base nitrogenada responsável por diferenciar cada um dos quatro tipos de nucleotídeos. A molécula de DNA é constituída de duas cadeias de nucleotídeos dispostas de modo antiparalelo. Ou seja, uma cadeia na direção 5' para 3', e a outra na direção oposta, de 3' para 5', como mostra a Figura 1.1. Ambas as cadeias são mantidas juntas por meio de ligações químicas, conhecidas como pontes de hidrogênio, por meio da qual a base adenina (A) se liga a timina (T), e citosina (C) a guanina (G) (Pierce, 2004). 


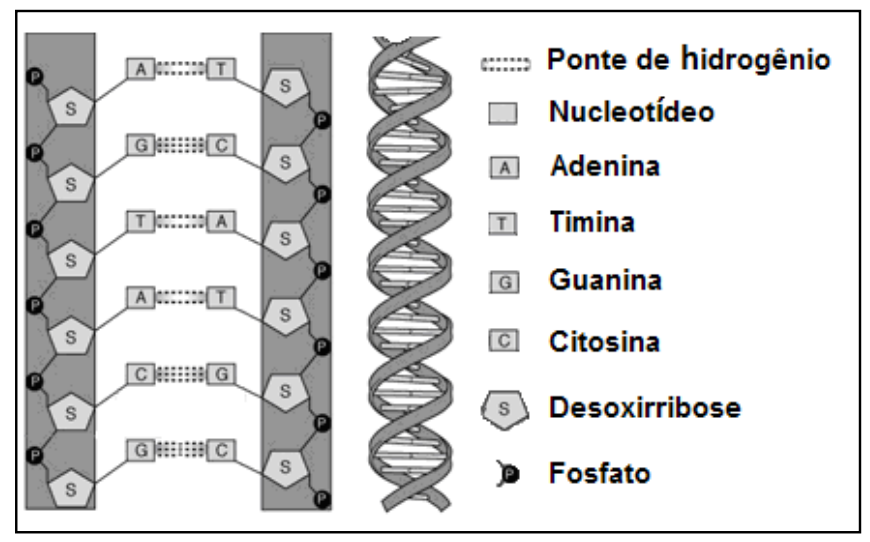

Figura 1.1 - Representação da molécula de DNA

Outro tipo de ácido nucléico é o RNA, ou ácido ribonucléico, o qual possui composição química similar ao DNA, cuja diferença está na composição química do açúcar que compõe o nucleotídeo, onde uma ribose está no lugar da desoxirribose, e na substituição da base nitrogenada timina $(\mathrm{T})$ por uma uracila $(\mathrm{U})$, como mostra na Figura 1.2.

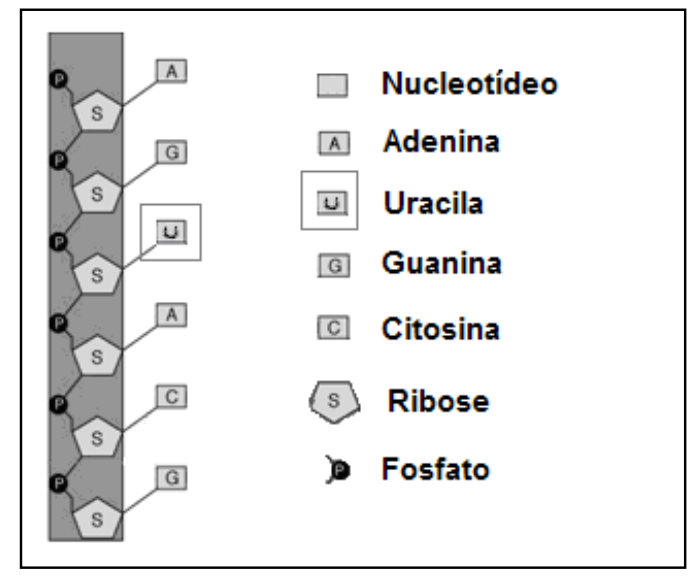

Figura 1.2 - Representação da molécula de RNA

Uma unidade básica do código genético são os códons, formados pelo conjunto de três nucleotídeos que codificam um único aminoácido. Com três nucleotídeos por códon, existem 64 códons possíveis, o suficiente para representar 20 aminoácidos diferentes, sendo esses as unidades formadoras das proteínas. Porém, para que a síntese de proteína aconteça, é necessário que dois processos importantes ocorram dentro das células, chamados transcrição e tradução. A transcrição é o processo de síntese de RNAm pela RNA polimerase a partir da dupla fita do DNA, enquanto que a tradução é o processo pelo qual a mensagem codificada 
pelo RNAm é traduzida pelos ribossomos, resultando na formação da cadeia polipeptídica correspondente (Pierce, 2004).

As fases do processo de transcrição e tradução podem ser vistos na Figura 2.

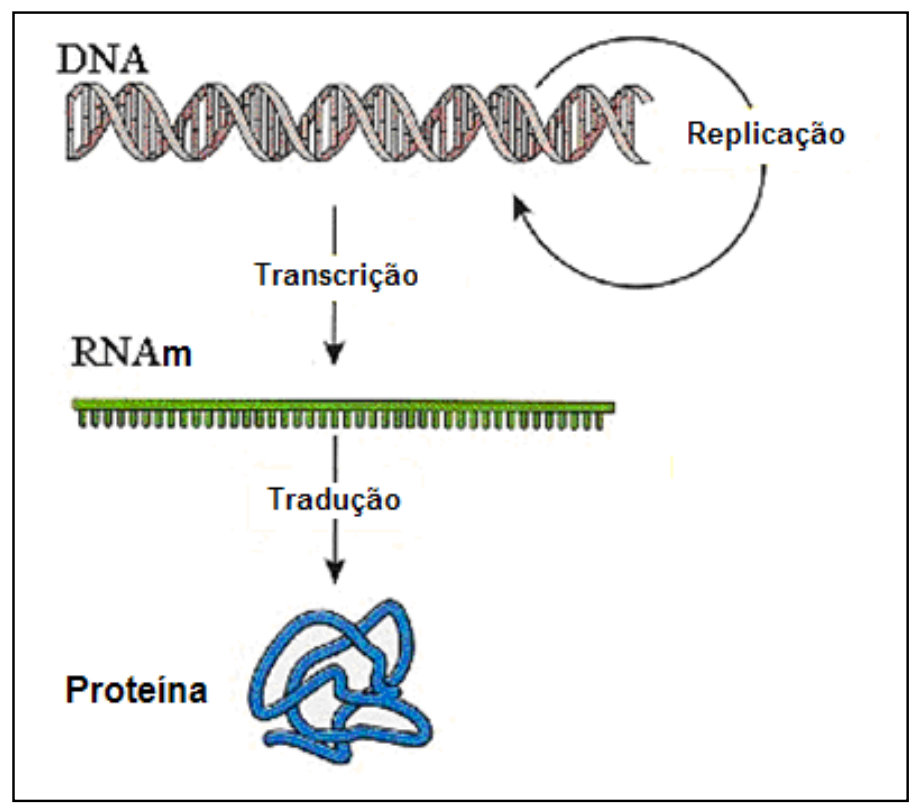

Figura 2 - Processo de transcrição do DNA em RNAm para a síntese de proteína

\subsubsection{Seqüenciamento de genoma}

Um genoma consiste de todo material genético de um organismo, sendo constituído, geralmente, por uma ou mais moléculas de DNA na vasta maioria dos seres, ou RNA, no caso de algumas famílias de vírus. Já o seqüenciamento é o processo que determina a ordem das sequiências de nucleotídeos ao longo da molécula de DNA.

Um dos objetivos do projeto de seqüenciamento é a identificação dos genes presentes no genoma. Uma vez identificados os nucleotídeos dos genes, eles podem ser usados para inferir as seqüências de aminoácidos das proteínas. Desse modo, a proteína pode ser sintetizada ou isolada e suas propriedades estudadas para determinar sua função (Pierce, 2004). 


\subsubsection{Método de Sanger}

No projeto de seqüenciamento, um procedimento muito utilizado para identificação das bases do DNA é o método de terminação da cadeia, também conhecido como método de Sanger (Sanger et al., 1977). Esse método é baseado na capacidade da enzima DNA polimerase estender a cadeia polinucleotídica a partir de um oligonucleotídeo iniciador (primer), ligado em uma das fitas molde por meio de reação de PCR. Como as fitas de DNA são complementares, a partir do molde, a enzima adiciona o nucleotídeo complementar no grupo hidroxila livre (OH) na posição 3', componente do desoxinucleotídeo anterior (dNTP).

Para identificar a sequiência de uma molécula de DNA, é necessário adicionar a essa reação nucleotídeos que interrompam a polimerização da cadeia, que são denominados didesoxinucleotídeo (ddNTP), nucleotídeos em que a pentose perdeu o grupo hidroxila da posição 3' $(\mathrm{OH})$ necessário à continuidade da polimerização da cadeia. Durante os ciclos de polimerização, os ddNTPs são incorporados aleatoriamente, produzindo fragmentos de tamanhos diferentes. A mistura de fragmentos é submetida a um seqüenciador automático para a realização da eletroforese, técnica de separação de moléculas baseada em seu peso molecular e tamanho, por meio de uma diferença de potencial elétrico. Como a carga da molécula de DNA é negativa, as moléculas migram para o pólo positivo. As moléculas de menor tamanho e peso molecular migram mais rapidamente que as moléculas maiores e mais pesadas, criando uma ordenação dos fragmentos (Carraro e Kitajima, 2002).

Nos sequienciadores automáticos, os diferentes ddNTPs estão ligados a moléculas fluorescentes, denominadas cromóforos, que, quando estimuladas por raio laser, emitem diferentes comprimentos de ondas, sendo reconhecidas por programas apropriados. Ao final do processo, a imagem gerada é chamada eletroferograma, com os picos representando a intensidade das cores lidas, e letras representando os nucleotídeos correspondentes aos picos, como mostram as Figuras 3.1 e 3.2. 


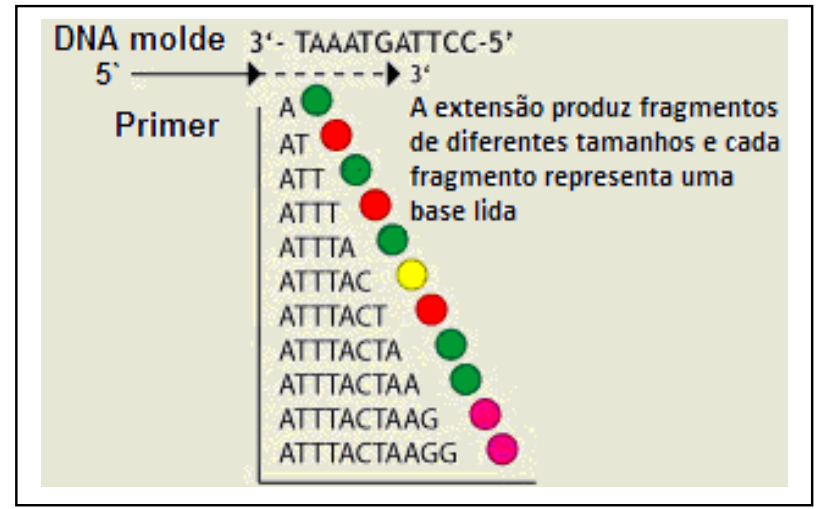

Figura 3.1 - Amplificação dos fragmentos de DNA interrompidos por um ddNTP

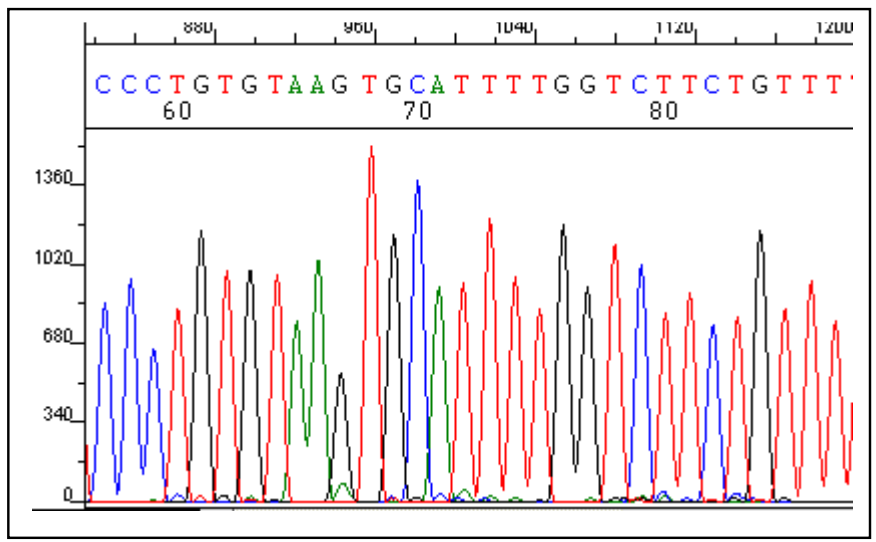

Figura 3.2 - Eletroferograma, no qual cada pico representa uma base lida do DNA

\subsubsection{Seqüenciamento de genoma pela técnica de shotgun}

Para seqüenciar completamente um genoma bacteriano, ou regiões do DNA, que é longo demais para o seqüenciamento direto, uma abordagem muito utilizada é a técnica de shotgun (Fleischmann et al., 1995). Nessa abordagem, o DNA do organismo em questão é isolado e bibliotecas de DNA genômico são elaboradas e servem como molde para posterior seqüenciamento. As bibliotecas genômicas são produzidas por meio da quebra mecânica (sonicação ou nebulização) das seqüências de DNA, o que produz fragmentos aleatórios da seqüência do genoma. O produto obtido pela fragmentação é separado por tamanho, sendo que essa separação geralmente é realizada por meio de eletroforese em gel de agarose para extração e purificação dos fragmentos de DNA nos tamanhos desejados. O tamanho dos 
fragmentos separados pode variar de 1 a $4 \mathrm{Kbp}(1 \mathrm{Kpb}=1.000$ pares de bases $)$, dependendo da estratégia adotada (Carraro e Kitajima, 2002).

Os produtos da fragmentação são inseridos em vetores especiais, como plasmídeos, e então, inseridos em linhagens apropriadas de bactérias por processo denominado transformação. Esse processo consiste na inserção dos plasmídeos com os insertos do DNA genômico dentro de bactérias, como a Escherichia coli, para gerarem cópias idênticas dos fragmentos durante o processo de replicação. Durante o processo de replicação, as bactérias formarão colônias e cada cultura de colônia individualizada será submetida à extração dos plasmídeos. Os plasmídeos extraídos contêm o inserto do DNA genômico do organismo em questão, e suas seqüências são obtidas ao serem submetidas à reação de seqüenciamento pelo método de Sanger (Carraro e Kitajima, 2002).

Durante a fase de seqüenciamento, periodicamente, realiza-se a montagem do genoma por meio de softwares específicos, tais como, phrap (http://bozeman.mbt.washington.edu/phrap.docs/phrap.html), CAP3 (Huang e Madan, 1999) TIGR Assembler (Sutton et. al., 1995). Esses programas utilizam algoritmos de alinhamento de seqüências textuais. Os passos resumidos para a montagem podem ser definidos em: leitura dos fragmentos já digitalizados, localização de redundâncias entre as sequiências de DNA e sobreposição dos fragmentos nas regiões em comum, formando sequiências maiores, os contigs. A montagem só é eficaz devido ao método aleatório de clonagem, que possibilita a redundância entre os fragmentos e permite assim que as seqüências sejam alinhadas umas às outras. Isso garante também a reconstituição da seqüência genômica original (Carraro e Kitajima, 2002). Após essa primeira etapa de montagem do genoma, fragmentos maiores são clonados em cosmídeos e seqüenciados. Essa segunda etapa é importante para a montagem do genoma completo do organismo, já que a primeira normalmente produz sequiência incompleta, apresentando algumas regiões não seqüenciadas (Prosdocimi et al., 2002).

Em projetos genomas de organismos eucariotos, que geralmente possuem grandes seqüências de DNA, normalmente prefere-se adotar uma técnica conhecida como shotgun hierárquico. Nessa técnica, o DNA inteiro do organismo é primeiramente inserido em grandes vetores de clonagem, como cromossomos artificiais de bactérias (BAC, do inglês Bacterial Artificial Chromosome) ou de leveduras (YAC, do inglês Yeast Artificial Chromosome). Depois é realizado um shotgun desses grandes fragmentos dos vetores, gerando assim, fragmentos menores que são agora clonados em vetores plasmidiais para o seu 
seqüenciamento. Portanto, tais projetos consistem de duas etapas, a montagem de cada um dos grandes fragmentos clonados nos BACs e YACs, e montagem final que reunirá as seqüências completas dos BACs e YACs para a reconstituição da informação genômica inicial (Prosdocimi et al., 2002).

\subsubsection{Pirosequenciamento}

A nova geração de seqüenciadores realiza o seqüenciamento de DNA em tempo real e se baseia na técnica de detecção do pirofosfato ( $\mathrm{PPi}$, do inglês Pyrophosphate), liberado durante a síntese de DNA. Em uma sequiência de reação enzimática, a luz visível emitida é usada na detecção do nucleotídeo incorporado à sequiência do DNA (Ronaghi, 2001). O piroseqüenciador possibilita o seqüenciamento de milhões de bases em poucas horas e conta com a vantagem de dispensar as etapas de clonagem, utilizada pelo método de Sanger (Goldberg et al., 2006).

Embora essa metodologia permita o seqüenciamento de genomas em poucas horas, o pirosequenciamento tem como limitação de sua tecnologia, a produção de pequenas seqüências de DNA que variam entre 50 e 350 bases por read. Com fragmentos curtos, adotase a abordagem chamada seqüenciamento híbrido, a qual faz uso concomitante de seqüências produzidas pelo método de Sanger e pirosequenciamento no auxílio às ferramentas de montagem de genomas (Chaisson e Pevzner, 2008).

Segundo Goldberg et al. (2006), empregar o uso do sequienciamento híbrido é uma abordagem capaz de produzir alta qualidade com baixo custo de seqüenciamento e, ao mesmo tempo, solucionar os problemas encontrados durante os projetos genomas por ambas as técnicas. Sendo assim, Goldberg definiu as estratégias para o melhor custo-benefício em ambas as abordagens de seqüenciamento. A estratégia foi baseada em resultados obtidos no seqüenciamento de 6 genomas microbianos. A Figura 4 aborda as melhores estratégias a serem aplicadas aos projetos genomas, a fim de produzir montagens de alta qualidade aliadas ao baixo custo. 


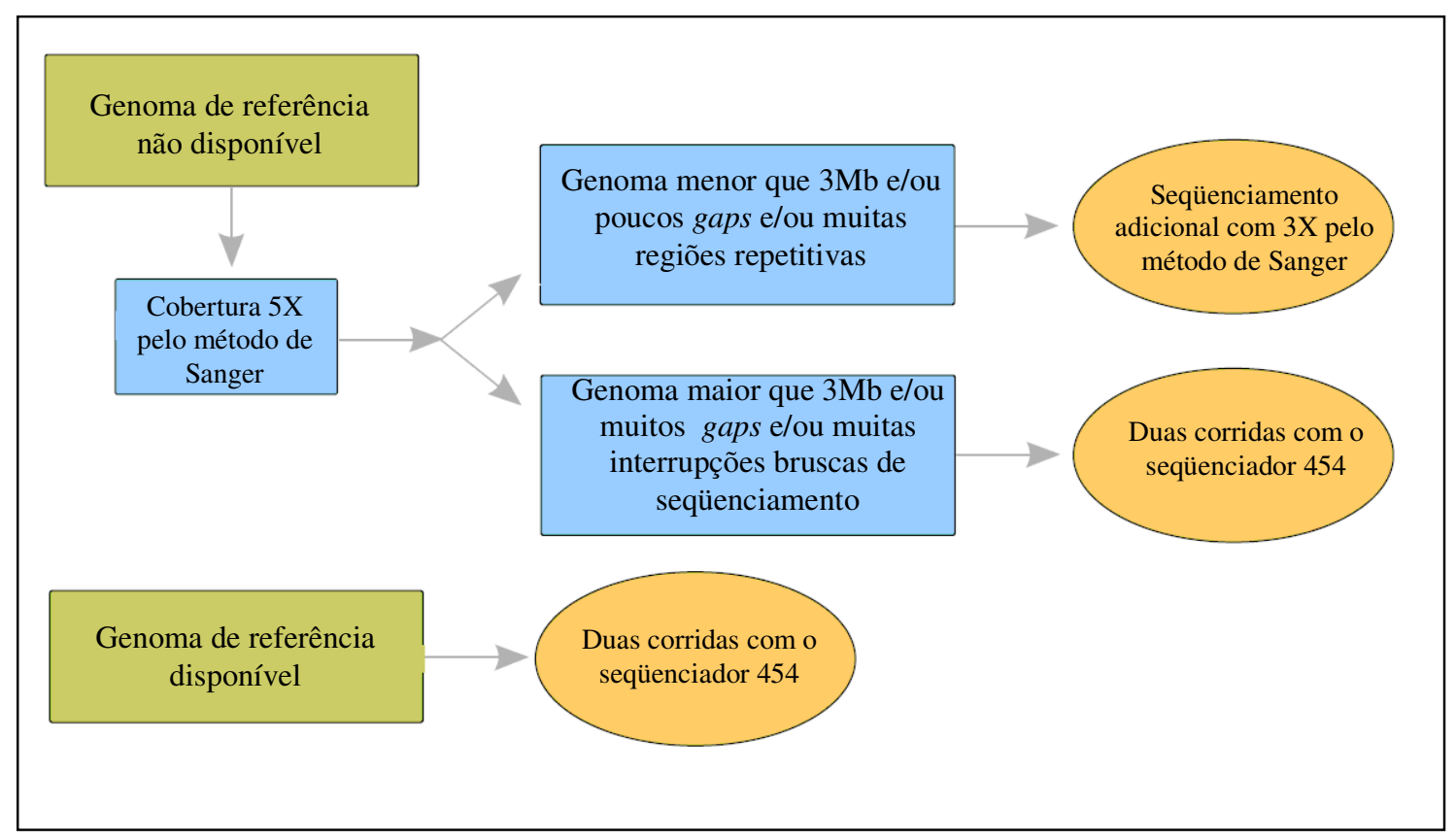

Figura 4 - No seqüenciamento de organismos com genomas menores de $3 \mathrm{Mb}$ e/ou baixo número de gaps e/ou alto número de regiões repetitivas, foi feita a cobertura do genoma 8 vezes pelo método de Sanger para alcançar a abordagem de melhor custo-benefício. Aos organismos maiores de $3 \mathrm{Mb}$, e/ou muitos gaps nas seqüências, e/ou muitas regiões com paradas bruscas durante o seqüenciamento, foi usado um seqüenciamento inicial cobrindo 5 vezes o genoma pela método de Sanger, seguidos de 2 corridas usando o pirosequenciamento para alcançar a abordagem de melhor custo-benefício

No trabalho realizado por Goldberg, o seqüenciamento pelo método de Sanger obteve melhores resultados em relação ao custo-benefício quando aplicado ao seqüenciamento de genomas menores que $3 \mathrm{Mb}$ (milhões de bases) e/ou baixo número de gaps, e/ou alto número de estruturas repetitivas, enquanto a técnica que utiliza o seqüenciamento híbrido obteve melhores resultados quando aplicada a genomas maiores que $3 \mathrm{Mb}$ e/ou muitos gaps, e/ou muitas regiões com dificuldades de seqüenciamento por apresentarem paradas bruscas (hard stops). Já o pirosequenciamento foi recomendado apenas para o resequenciamento de genomas, isto é, genomas que possuem sequiências como referência.

\subsubsection{Plataforma de seqüenciamento Solid e Solexa}

Além do pirosequenciamento (conhecido como 454) desenvolvida pela empresa Roche ${ }^{\circledR}$, existe outras plataformas de seqüenciamentos, tais como Solid (desenvolvida pela Applied biosystems ${ }^{\circledR}$ ) e Solexa (desenvolvida pela Illumina $\left.{ }^{\circledR}\right)$. Uma diferença fundamental 
entre as plataformas da nova geração de seqüenciamento (454, Solid e Solexa) é o tamanho e a quantidade de fragmentos produzida por cada uma delas. Por exemplo, enquanto uma corrida de 454 produz em média 1 milhão de reads de fragmentos variando entre tamanho de 200 a 400 bases, o Solid e Solexa produzem em torno de 100 milhões de reads variando o tamanho entre 50 e 75 bases. Sendo assim, o uso da plataforma Solid e Solexa é recomendado para o resequenciamento de genomas, transcriptomas, metatranscriptomas, identificação de polimorfismos, enquanto que a plataforma 454 é recomendada para o seqüenciamento de novos genomas (Dohm et al., 2007).

\subsubsection{Técnica de microarranjo de DNA}

Muitos indícios importantes sobre o funcionamento gênico vieram do conhecimento de quando e onde os genes se expressam. Dessa forma, a análise simultânea da expressão de milhares de genes, em um único experimento, possibilitou que a técnica de microarranjo de DNA se tornasse ferramenta poderosa quando aplicada em estudos funcionais gênicos. $\mathrm{O}$ emprego da técnica de microarranjo de DNA tem permitido grande avanço nos estudos de expressão gênica em vegetais, humanos, diversos gêneros de bactérias e leveduras. Em relação aos sistemas microbianos, áreas como fisiologia, patogênese, epidemiologia, ecologia, filogenia, vias de manipulação e otimização da fermentação tornaram-se tópicos comuns de aplicação de microarranjos de DNA (Yeo et al., 2001; Letowski et al., 2003).

Contudo, a técnica de microarranjos de DNA é baseada na hibridização de ácidos nucléicos, na qual um fragmento conhecido de DNA é usado como uma sonda para encontrar seqüências complementares. A sonda em geral é fixada em algum suporte sólido, tal como filtro de náilon ou lâmina de vidro. Qualquer seqüência de ácido nucléico que seja complementar à sonda irá se ligar a ele. Os ácidos nucléicos na mistura são marcados com um marcador radioativo ou fluorescente, de modo que as moléculas ligadas à sonda possam ser facilmente detectadas (Pierce, 2004).

Em um microarranjo (também chamado chip de genes), vários fragmentos de DNA conhecidos são fixados a um suporte sólido em padrão ordenado, ou arranjo, em geral como uma série de pontos. Esses fragmentos de DNA (as sondas) em geral correspondem a genes conhecidos. Quando o microarranjo tiver sido elaborado, os RNAm, DNA ou DNA complementar (DNAc), isolados de células experimentais são marcados com nucleotídeos 
fluorescentes e aplicados ao arranjo. Qualquer uma das moléculas de DNA ou RNA que são complementares às sondas no arranjo irão se hibridizar com elas e emitir fluorescência, que pode ser detectada por um scanner automatizado. Arranjo contendo dezenas de milhares de sondas pode ser aplicado a uma lâmina de vidro com alguns centímetros de tamanho (Pierce, 2004).

A Figura 5 ilustra um processo experimental básico de microarranjo de DNA, no qual os clones de DNA, contendo sequiências gênicas, são amplificados por meio de PCR e impressos em uma lâmina de vidro. Os RNAm de células experimentais são convertidos em DNA complementares e marcados com nucleotídeos de fluorescência vermelha. Os RNAm das células controle são convertidos em DNA complementares e marcados com nucleotídeos de fluorescência verde. Os DNA complementares marcados são misturados e hibridizados às sondas de DNA contidas em uma lâmina.

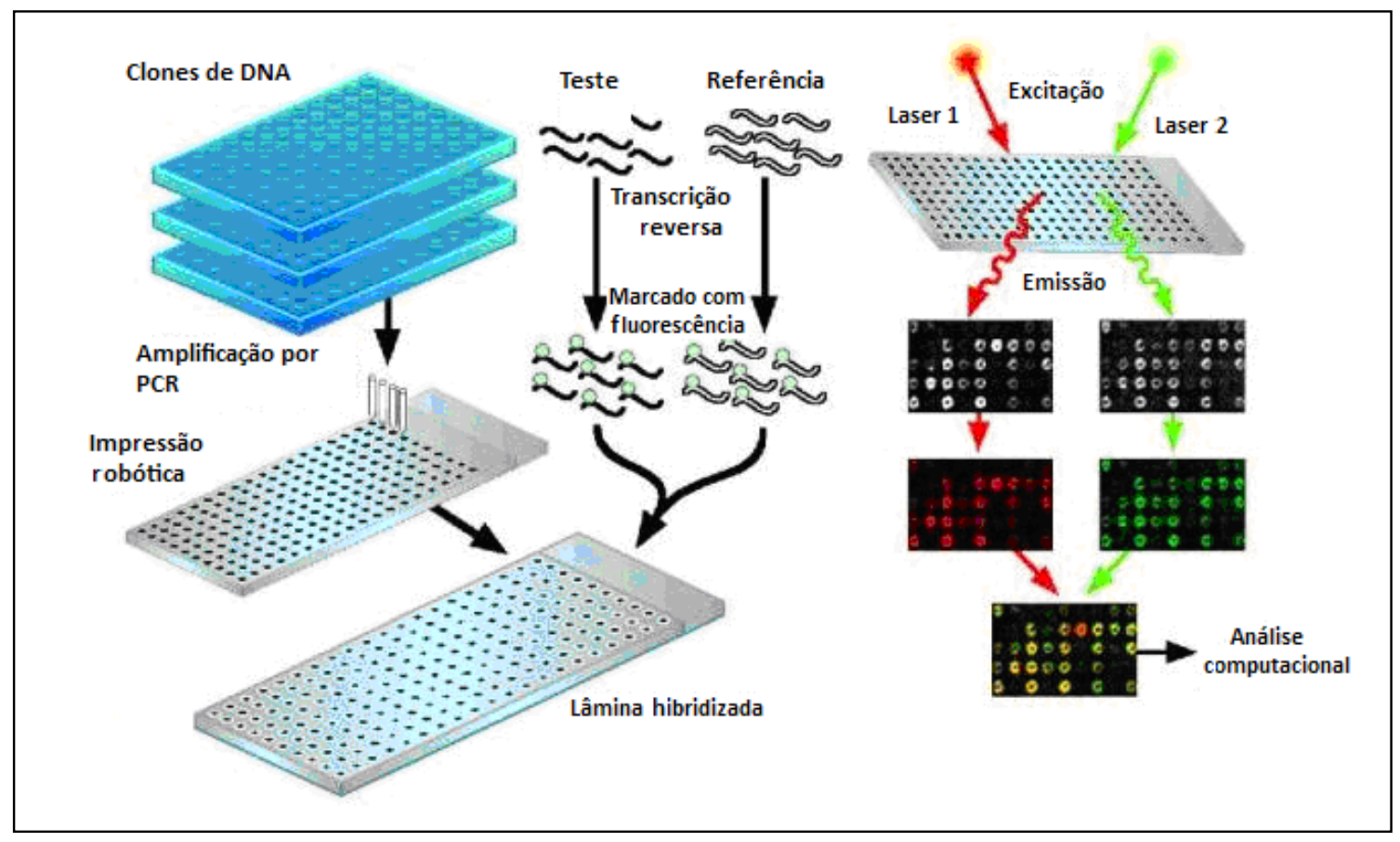

Figura 5 - Esquema ilustrativo dos procedimentos da técnica de microarranjo de DNA

Após o processo de hibridização, a lâmina é escaneada e obtêm-se duas imagens, sendo uma para o comprimento de onda vermelho e outra verde. A intensidade dos pontos observados indica a eficiência da hibridização da sonda contida no microarranjo com os alvos de DNA complementares marcados fluorescentemente. As duas imagens obtidas são sobrepostas por meio de programas específicos e o resultado da sobreposição é analisado. A cor vermelha indica a hiperexpressão de um gene nas células experimentais em relação a das 
células controle, enquanto verde indica a subexpressão de um gene nas células experimentais em relação ao das células controle. Amarelo indica expressão igual nas células controle e experimental, e nenhuma cor indica falta de expressão tanto nas células experimentais quanto nos controles (Pierce, 2004).

\subsubsection{Técnica de CGH}

A técnica de comparação de genomas por hibridização (CGH) utiliza microarranjo de DNA e possibilita a comparação de genomas completos, ou grandes conjuntos de genes de uma estirpe seqüenciada, como método alternativo às técnicas de comparação gênicas, baseadas em um ou poucos genes (Porwollik et al., 2002).

Na técnica de $\mathrm{CGH}$, a hibridização gênica de um genoma no microarranjo, identifica genes que estão ausentes, presentes ou que são altamente divergentes do genoma de referência. No entanto, o relacionamento genético é determinado baseado nos padrões de presença e ausência dos genes entre os genomas. Essa técnica pode ser usada para inferir relacionamentos filogenéticos, pois, um único arranjo pode conter centenas ou milhares de fragmentos de DNAs. Desse modo, uma simples lâmina tem o potencial de identificação de amplo número de microrganismos ou genes de uma só vez, proporcionando que mais informação seja incorporada em uma análise (Edwards-Ingran et al., 2004).

\subsubsection{Tipos de microarranjo}

A plataforma sólida mais utilizada na confecção dos arranjos é a lâmina de vidro, do tipo usado em microscopia, que depois de ter as sondas imobilizadas na sua superfície, é normalmente referida como slide ou simplesmente lâmina de microarranjo. Basicamente existem duas formas de distribuir as sondas em um microarranjo de DNA. A primeira, mais simples, é feita por robôs de alta precisão que utilizam agulhas especiais para depositar as amostras de DNA na superfície de uma lâmina de vidro, processo que também é conhecido como "impressão do slide". Normalmente essas amostras são constituídas de oligonucleotídeos pré-sintetizados, DNAs complementares produzidos em projetos de seqüenciamento, ou, ainda, produtos de amplificação por PCR. A segunda, mais complexa, 
utiliza processos especiais (por exemplo, fotolitografia) para realizar a síntese química de oligonucleotídeos diretamente sobre a superfície da lâmina de vidro (Rosa et al., 2007).

Entretanto, a tecnologia básica de microarranjo apresenta diversas variações, dependendo do substrato (lâminas de vidro ou de sílica), tipo de sonda (oligonucleotídeos de cadeia curta, oligonucleotídeos de cadeia longa, DNAc ou produtos de PCR), do método de deposição das amostras (impressão por robôs ou síntese baseada na tecnologia de semicondutores), além de variedade de técnicas de extração e marcação do RNA, bem como de protocolos de hibridização. Dessa maneira, diversos tipos de lâminas podem ser encontrados para espécies animais e vegetais, as quais são produzidas por empresas ou por instituições de pesquisa e universidades (Rosa et al., 2007).

\subsubsection{Metagenoma}

Metagenoma é o nome dado ao estudo do conteúdo genômico de uma mistura complexa de microrganismos encontrados em um determinado habitat. Os principais objetivos desses estudos são identificar as populações de microrganismos que estão presentes em uma microbiota para, em seguida, identificar as funções que cada microrganismo tem dentro desse ambiente. Amostras metagenômicas podem ser obtidas a partir dos mais diferentes ambientes, incluindo vários microambientes dentro do corpo humano, amostras de solos, ambientes extremos, tais como minas profundas e as várias camadas dentro dos oceanos. Portanto, devido à existência de microrganismos nas diversas condições ambientais existentes no planeta, a diversidade de microrganismos é estimada na escala de dezenas a centenas de milhões de espécies (Harkins e Jarvie, 2007).

Atualmente, duas abordagens são comumente usadas para o seqüenciamento de amostras metagenômicas. Na abordagem tradicional, o DNA é clonado em BACs ou Cosmídeos e o processo de seqüenciamento pelo método de Sanger é usado para determinar as seqüências nucleotídicas. A nova abordagem utiliza as plataformas avançadas de seqüenciamento de DNA. Com o pirosequenciamento, o DNA metagenômico é seqüenciado diretamente sem a etapa de clonagem, possibilitando a identificação de um maior número de genes e diminuindo o custo de execução dos projetos de metagenômica (Meyer et al., 2008). 


\subsection{Fundamentos computacionais}

Tendo em vista o grande volume de dados a serem processados em diversos tipos de projetos de bioinformática, torna-se necessário o uso de ferramentas computacionais para auxílio às análises diárias dos experimentos laboratoriais. Para tanto, o desenvolvimento de sistemas de workflow (fluxo de trabalho), tem por finalidade ajudar o pesquisador nas execuções de suas tarefas, de modo a fornecer controle automatizado das atividades laboratoriais. Nessa seção são apresentados conceitos sobre workflow (Hollinsworth, 1995), álgebra de processos (Fokkink, 2000) e NPDL (Braghetto et al., 2006).

\subsubsection{WorkFlow}

Um conceito bastante difundido em sistemas gerenciadores de processos de negócio é o de workflow (Hollinsworth, 1995). Um workflow, segundo a definição da WfMC (do inglês Workflow Management Coalition) é a automação do processo de negócio, na sua totalidade ou em partes, por meio da qual documentos, informações ou tarefas são passados de um participante ao outro para execução de uma ação, de acordo com um conjunto de regras procedurais (Hollinsworth, 1995). Também segundo a WfMC, um sistema de gerenciamento de workflow (WFMS, do inglês Workflow Management System) é um sistema que define, cria e gerencia a execução de workflows por meio do uso de software.

Em bioinformática, como em outras áreas, muitas das tarefas a serem executadas pelos pesquisadores envolvem o uso de vários softwares. Assim, uma coleção de dados produzidos por um programa pode ser o conjunto de dados de entrada para o próximo programa. No entanto, o controle da execução desses programas, em projetos complexos, não é tarefa trivial. Dessa maneira, reforça a importância do uso de workflows científicos (workflow utilizado na execução de atividades em experimentos científicos) (Ludäscher et al., 2005).

Como exemplo de workflow em bioinformática, pode-se citar o pacote phred/phrap/consed (Nickerson et al., 1997). Esse pacote contém um script que controla os passos a serem executados em cada fase da montagem do genoma. Além dos scripts prontos, geralmente os pesquisadores utilizam linguagens de scripts para implementar os seus próprios 
workflows, tendo em vista os recursos que essas linguagens oferecem para fazer chamadas de programas.

Entretanto, para o controle confiável de execução de fluxos de sistemas é fundamental a utilização de linguagens que forneçam subsídios para a modelagem e para o controle dos processos dos sistemas. Entre essas linguagens, pode-se citar redes de Petri (Murata, 1989) e a álgebra de processos (Fokkink, 2000).

\subsubsection{Padrões básicos de controle de fluxo}

No intuito de criar um padrão de controle e execução de fluxo de sistemas, Aalst et al. (2003) têm trabalhado na definição, desde as formas básicas às mais complexas de controle de fluxos, independente de uma linguagem de especificação. Nesse esforço, 20 padrões de controle de fluxos em workflows foram definidos (Aalst et al., 2003). Os padrões básicos de controle de fluxo referem-se a construções básicas, presentes na maioria das linguagens de modelagem de workflows.

A seguir, os cinco padrões básicos de controle de fluxos serão apresentados.

\section{- Padrão 1. Seqüência}

Série ordenada de atividades, na qual uma atividade é habilitada para execução somente depois que a atividade anterior terminou a sua execução.

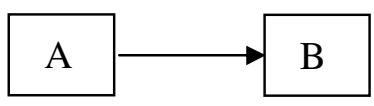

Figura 6.1 - Seqüência

Exemplo: a atividade $\mathbf{B}$ só é habilitada para execução após o término da execução de $\mathbf{A}$.

\section{- Padrão 2. Divisão paralela}

Um ponto no processo no qual um caminho único de fluxo é dividido em dois ou mais caminhos, de forma que duas ou mais atividades possam começar simultaneamente ou em qualquer ordem. 


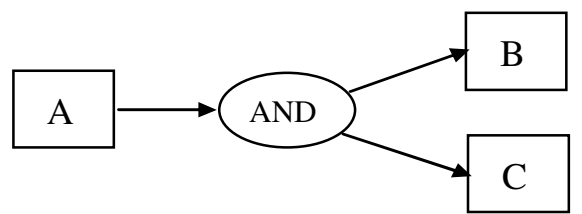

Figura 6.2 - Divisão paralela

Exemplo: a atividade $\mathbf{A}$ é executada e habilita a execução de $\mathbf{B}$ e $\mathbf{C}$ em paralelo (ou seja, em qualquer ordem ou simultaneamente).

\section{- Padrão 3. Sincronização}

Um ponto no processo, no qual múltiplas atividades paralelas convergem para um caminho único de fluxo. Todas as atividades devem estar finalizadas para que o processo possa continuar.

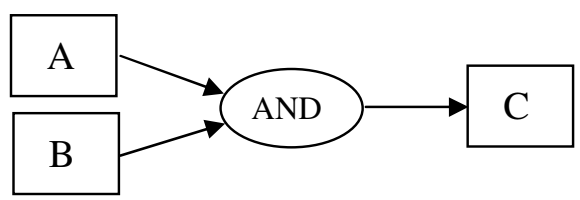

Figura 6.3 - Sincronização

Exemplo: a atividade $\mathbf{C}$ é habilitada somente depois que $\mathbf{A}$ e $\mathbf{B}$ tiverem sido executadas

\section{- Padrão 4. Escolha exclusiva}

Um ponto no processo no qual, baseado em uma decisão ou nos dados de controle do workflow, um, entre os diversos caminhos, é escolhido. Assim, o caminho divide-se em alternativas exclusivas.

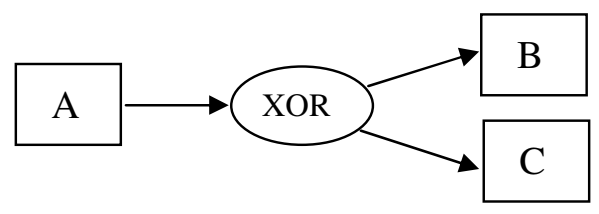

Figura 6.4 - Escolha exclusiva

Exemplo: as atividades $\mathbf{B}$ e $\mathbf{C}$ são habilitadas após a execução de $\mathbf{A}$, mas somente uma delas será escolhida implicitamente para a execução. 


\section{- Padrão 5. Junção simples}

Um ponto no processo no qual dois ou mais caminhos alternativos se juntam, sem ser necessária a sincronização. Assume-se, nesse padrão, que não ocorre execução em paralelo nos diversos caminhos alternativos.

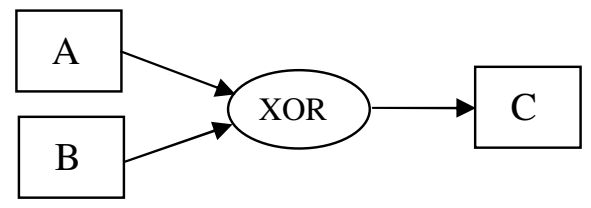

Figura 6.5 - Junção simples

Exemplo: inicialmente, as atividades A e B estão habilitadas; após a execução de uma delas, $\mathbf{C}$ é habilitada.

Com a definição desses cinco padrões básicos de controle de fluxos é possível controlar e gerenciar a execução dos processos de diversos projetos. A descrição mais detalhada de todos os padrões de controle de fluxo pode ser encontrada em Aalst et al. (2003).

\subsection{3 Álgebra de processos}

De maneira geral, podemos definir que o comportamento de um sistema de computação consiste de processos e dados (Fokkink, 2000), no qual os processos são os mecanismos de controle para a manipulação dos dados. Um sistema de computação é composto por vários processos que são executados concorrentemente.

Devido à relação entre os processos, o comportamento de um sistema pode ser representado por meio de grafos de processos. Nesse caso, um conjunto de nós ou vértices é usado para representar os estados do sistema e as arestas rotuladas entre os nós para representar as transições de estados. A álgebra de processos (Fokkink, 2000) trata da especificação e manipulação de processos por meio de uma coleção de operadores, constituindo um arcabouço formal para os processos e dados. A avaliação das expressões da álgebra de processos permite detectar propriedades indesejáveis e formalmente produzir propriedades desejáveis.

A álgebra de processos de acordo com Fokkink (2000) é composta por um conjunto de ações (ou eventos), um conjunto de operações e um conjunto de axiomas descrevendo as 
propriedades dos operadores. A álgebra de processos contém operadores básicos e operadores para controles avançados, adicionalmente pode ser estendido com novos operadores para aumentar o seu poder de expressividade ou facilitar a especificação do comportamento de sistemas (Bergstra et al., 2001).

A possibilidade de criar novos operadores permite que diferentes padrões de álgebras de processos sejam criados, tais como: CCS (do inglês Calculus of Communicating Systems) (Milner, 1982), CSP (do inglês Communicating Sequential Processes) (Hoare, 1978) e a ACP (do inglês Algebra of Communicating Processes) (Bergstra et al., 2001), sendo esta última usada como referência para o desenvolvimento deste trabalho.

Com objetivo de atender aos requisitos básicos de controles de fluxos, os operadores básicos padrões usados na modelagem em álgebra de processos são definidos da seguinte forma:

a) Composição seqüiencial - operador ( • ): o termo de processo A . B significa que, inicialmente, somente o termo A está habilitado para execução. O termo B será habilitado para execução somente após o fim da execução de A;

b) Composição alternativa - operador ( + ): o termo de processo A + B significa que, inicialmente, ambos os termos A e B estarão habilitados para execução. Porém, somente um deles será executado;

c) Composição paralela - operador ( II ): o termo de processo A II B significa que os termos A e B podem ser executados paralelamente, dividindo a linha de controle em duas.

A descrição detalhada de todos os operadores da álgebra de processos pode ser encontrada em Fokkink (2000).

\subsubsection{NPDL - Linguagem para definição de plano de navegação}

Com o objetivo de viabilizar o controle de processos de negócio para um modelo relacional de dados, foi criada a NPDL (Braghetto et al., 2006). Essa linguagem é uma extensão da linguagem SQL (do inglês Structured Query Language) e se baseia no conceito 
de plano de navegação da arquitetura RiverFish (Ferreira et al., 2006), e em operadores de álgebra de processos. Assim como na álgebra de processos, processos em NPDL são definidos por expressões algébricas envolvendo ações e operadores.

A linguagem NPDL utiliza a álgebra de processos como arcabouço formal para oferecer subsídios para a criação, execução e gerenciamento de processos descritos nas expressões da álgebra de processos. O uso da NPDL possibilita que expressões da álgebra de processos sejam tratadas sem que os usuários necessitem desenvolver interpretadores específicos para o tratamento sintático dessas expressões.

A seguir, serão apresentados alguns operadores da NPDL, usados nos controles das regras de seleção dos clones ótimos.

a) Composição paralela entrelaçada (operador $\mid *$ ): o termo de processo $\left.A\right|^{*} B$ significa que os termos $A$ e $B$ podem ser executados em qualquer ordem (exemplo: $A . B+B . A)$, mas não podem ser executados de forma paralela.

b) Composição multiconvergente (operador $\&$ ): o termo de processo $A \& B$ significa que o termo $B$ será habilitado para execução após o término da execução de cada linha de controle do termo $A$. Por exemplo, o processo $P=(A \| B) \& C$ indica que $C$ será habilitado para execução duas vezes: uma após o término da execução do processo $A$ e outra após o término da execução do processo $B$.

c) Execução condicional (operador \%r sendo $r$, uma regra que retorna um valor booleano): o termo de processo \%r $A$ significa que o termo $A$ será habilitado para execução se o valor de retorno da regra $r$ (avaliada em tempo de execução) for verdadeiro. O complementar da execução condicional é representado por $\% ! r$, nesse caso, o termo $A$ será executado caso a regra $r$ retornar um favor falso.

Além dos operadores anteriormente descritos, a NPDL contém comandos que são usados para criar e definir os processos, como mostrados a seguir.

- CREATE - usado para criar os processos, regras e ações que serão definidas na expressão algébrica, por exemplo: 
- CREATE Process P;

- CREATE Rule r;

- CREATE Action $A, B$;

- SET - usado para atribuir uma expressão algébrica a um processo, por exemplo:

- $\operatorname{SET} \mathrm{P}=\frac{\circ}{0}(\mathrm{~A} . \mathrm{B})+\frac{\circ}{0} ! r(\mathrm{C})$;

A seguir, um exemplo de uma expressão em NPDL e sua definição.

- $\mathrm{P}=\frac{\circ}{\mathrm{r}}(\mathrm{A} . \mathrm{B})+\frac{\circ}{\mathrm{a}} \mathrm{r}(\mathrm{C})$;

Nessa expressão, P representa o processo que avalia o resultado da regra $r$ e decide qual a próxima ação a ser executada. Se a regra $r$ retornar um valor verdadeiro, primeiro será executada a ação A e, após o seu término, a ação B é habilitada para execução. Caso a regra $r$ retorne um valor falso, somente a segunda parte da expressão será habilitada. Dessa forma, a ação C será habilitada para execução.

A descrição detalhada de todos os operadores da linguagem NPDL pode ser encontrada em Braghetto et al. (2007). 


\section{Capítulo 3}

\section{Trabalhos relacionados}

Um dos pré-requisitos para o uso da tecnologia de microarranjo de DNA, nas análises de expressão gênica e comparação de genomas por CGH é o uso de lâminas com a presença de seqüências gênicas conhecidas. Tais seqüências podem ser obtidas por meio da síntese de oligonucleotídeos específicos para cada gene do genoma. A abordagem que sintetiza oligonucleotídeos em genomas fechados e anotados possibilita a identificação prévia de quais serão os genes presentes na lâmina. Essa abordagem foi adotada por Koide et al. (2004), para criar um microarranjo de DNA com seqüências gênicas conhecidas nos estudos de expressão gênica de duas estirpes da bactéria Xylella fastidiosa, sendo uma delas fitopatógena. Nesse trabalho, foram produzidas 2.692 seqüências de produto de PCR para criar o arranjo de DNA pela síntese oligonucleotídeos específicos (Koide et al., 2004).

Outro modo de compor o microarranjo para fins de análises de expressão gênica e CGH é por meio de sínteses de sondas de DNA específicas para cada gene do genoma. No trabalho de Giuntini et al. (2005), 6.229 sondas foram usadas nos estudos de comparação de genomas por hibridização (CGH) entre quatro diferentes estirpes da bactéria Sinorhizobium meliloti, com o intuito de analisar a variação genética em nível genômico. Nos experimentos conduzidos por Hauser et al. (2006), em análises de expressão gênica, foram sintetizadas 738 sondas de DNA para estudo do perfil transcricional nas análises simbióticas de genes de fixação de nitrogênio da bactéria Bradyrhizobium japonicum.

Entretanto, nem só em bactérias a técnica CGH vem sendo empregada, ela também tem sido utilizada com sucesso na comparação de estirpes de leveduras usando microarranjos como os de Watanabe et al. (2004). Esse estudo comparou estirpe de leveduras usando um microarranjo com sondas de 6.000 genes de Saccharomyces cerevisiae S288C, para obter informações sobre a determinação de espécies e alterações no número de cópias de genes entre elas. 


\subsection{Microarranjos compostos por clones de shotgun}

A abordagem usando seqüências produzidas pela técnica de shotgun para criar microarranjos, no qual os genes são identificados após o processo de hibridização e seqüenciamento dos clones, foi utilizada por Scott et al. (2006), no estudo da bactéria Roseburia inulinivorans estirpe A2-194. Esse trabalho identificou genes que são diferencialmente expressos durante as fases de crescimento em meio de cultura contendo glucose ou fucose, através de microarranjo composto por 4.884 clones de tamanho variando de 1 a 2 kb. Após a hibridização, 80 clones foram selecionados por análises estatísticas e seqüenciados completamente, com o intuito de identificar os genes presentes em suas seqüências. Nessa abordagem, os clones presentes na lâmina podem conter seqüências de mais de um gene, portanto, impede de saber a priori quais deles foram realmente expressos. Com os genes identificados, óligos específicos para cada gene foram sintetizados e submetidos a análises de expressão gênica pelo método de PCR quantitativo em tempo real (Scott et al., 2006).

Clones de shotgun da bactéria Xanthomonas axonopodis pv. citri foram selecionados por Moreira (2006), para compor um microarranjo de DNA. A seleção dos clones inicialmente foi realizada in silico através de scripts em linguagem Perl, com critérios específicos para os dados contidos no banco do genoma completo da $X$. citri. Por meio de análises in silico, 4.421 clones dos 46.462 disponíveis para análises foram selecionados. Após análises in silico, 1.782 clones foram descartados do projeto por apresentarem problemas, sendo eles: ORFs (do inglês Open Reading Frame) com fragmentos pequenos (menores que 200 bases) ou ORFs diferentes dos inicialmente identificados nos clones após os seus reseqüenciamentos. Desse modo, 2.639 clones foram usados para compor o microarranjo de DNA e usados nas análises estrutural e funcional do genoma da X. citri (Moreira, 2006).

O uso de clones de shotgun em microarranjos também foi utilizado em organismos superiores, como no caso da análise em uma região do cromossomo humano conduzido por $\mathrm{Li}$ et al. (2004). Nesse trabalho, a região 4q22-24 do cromossomo humano, que possui tamanho aproximado de $1.7 \mathrm{Mb}$, estava representada na lâmina por seqüência de clones de shotgun. $\mathrm{O}$ intuito das análises de hibridizações foi à localização de novas regiões de transcritos ainda não identificados pelos métodos tradicionais, sendo eles por softwares de predição de seqüências de exons, ou regiões identificadas pelo seqüenciamento de ESTs (do inglês 
Expressed Sequence Tag). As bibliotecas de DNAs complementares, alvos das hibridizações, foram extraídas dos seguintes tecidos: pulmão, fígado, medula óssea e cólon. Após as análises de hibridização entre os diferentes tecidos, foi possível a identificação de 166 novos transcritos de genes que anteriormente não constavam como exons por softwares preditores ou mesmo identificados no seqüenciamento de ESTs. Adicionalmente, foi identificada à presença de um splicing alternativo e a possível presença de um pseudogene. Portanto, o uso de microarranjo de seqüências de clones de shotgun demonstrou ser útil na identificação de novos transcritos e loci de genes conhecidos, como também em análises de splicing alternativo e no estabelecimento de ligação entre ESTs em genomas de eucarioto (Li et al., 2004).

\subsection{Análises em metagenomas}

Em projetos de metagenomas, o uso de bibliotecas de DNA de cosmídeos impressos em microarranjos é um método comumente usado na identificação de genes de interesse. Nessa abordagem, as seqüências dos clones presentes na lâmina são hibridizadas contra as seqüências de sondas sintetizadas contendo parte dos genes. Os clones hibridizados são fragmentados, sub-clonados e seqüenciados para que os genes identificados possam ser usados em análises funcionais (Pathak et al., 2009).

Uma abordagem alternativa a hibridização dos clones em microarranjos para identificar genes de interesse em bibliotecas metagenômicas é a análise função-dirigida, conhecida como function-driven screening. Nessa análise, os clones (geralmente Cosmídeos ou Fosmídeos) que contém os genes de interesse são identificados ao serem expressos em condições in vitro (como meios de cultura contendo um indutor apropriado) e selecionados para o seqüenciamento. Por meio dessa abordagem, Kim et al. (2009) isolaram e seqüenciaram completamente um clone contendo genes envolvidos na biossíntese de porfirinas a partir de uma biblioteca metagenômica composta por 107.000 clones de fosmídeos.

\subsection{Ferramentas de bioinformática}

Como apresentado nos projetos de seqüenciamento, para a comparação de genomas e análises de expressão gênicas, as ferramentas de bioinformática têm importante papel no 
auxílio às análises dos dados, no controle e na automatização dos processos. Desse modo, algumas ferramentas de bioinformática oferecem um conjunto integrado de funções, nas quais realizam tarefas específicas para cada fase do projeto. Uma ferramenta que tem essa propriedade de integrar funções é o SABIA - System for Automated Bacterial Integrated Annotation, um sistema que proporciona o controle e a execução de programas de análises em dados biológicos, empregado nos serviços de análises de sequiências, montagem de genomas bacterianos, predição e anotação dos genes (Almeida et al., 2004). Além do software SABIA, outras ferramentas de bioinformática usadas nos projetos genomas, com função de predição gênica e de anotação de genes são: GenDB (Meyer et al., 2003); Artemis (Rutherford et al., 2000); ERGO (Overbeek et al., 2003); GATO (Fujita et al., 2005), entre outras. Porém, entre as ferramentas de bioinformática citadas, nenhuma delas proporciona a geração automatizada dos fluxos dos processos por meio de um arcabouço algébrico, no qual garante precisão nas alterações e execuções das tarefas realizadas pelos usuários. O uso de álgebra de processos proporciona flexibilidade e eficiência para ferramentas de bioinformática.

\subsection{Workflow científico}

Um sistema de gerenciamento de workflow científico é desenvolvido especialmente para compor e executar uma série de passos, como também para gerenciar dados e tarefas computacionais relacionados especificamente na área científica. Atualmente, existem vários sistemas de workflows desenvolvidos para serem utilizado por cientistas nas áreas de astronomia, ciências da Terra e bioinformática.

Entre os sistemas de workflows desenvolvidos para área de bioinformática podemos citar:

- BioManager: workflow desenvolvido para análises e gerenciamento de dados de bioinformática (Cattley e Arthur, 2007);

- Ergatis: sistema baseado na web para criar, executar e monitorar pipelines de análises em bioinformática. Ele contém alguns componentes de análises de dados de bioinformática embutidos em seu sistema. A execução dos componentes é organizada de modo gráfico, assim permite criar pipelines altamente configuráveis (http://ergatis.sourceforge.net); 
- EGene: software que oferece controle na execução dos processos, sendo um sistema gerador de pipelines configurável para análises automatizadas de seqüências de DNAs, ESTs e montagem de genomas (Durham et al., 2005);

- Pegasys: software para execução e integração nas análises de seqüências biológicas (Shah et al., 2004).

- HCDC: banco de dados biológico para visualização, gerenciamento e publicação de imagens de experimentos biológicos (http://hcdc.ethz.ch).

O uso de sistemas gerenciadores de workflows científicos auxilia no gerenciamento de tarefas corriqueiras desenvolvidas nos laboratórios, e fornece subsídio para organizar todos os processos e fluxos de um sistema. 


\section{Capítulo 4}

\section{Materiais e métodos}

Para o desenvolvimento das regras de seleção de clones, primeiramente foi necessário entender a metodologia usada na montagem de genomas por meio da técnica de shotgun (Fleischmann et al., 1995). Por meio dessa técnica, as seqüências dos clones amplificados pelos oligonucleotídeos universais forward (senso) e reverse (anti-senso), aparecem difundidas entre as milhares de sequiências do genoma e podem ser encontradas em diferentes situações, sendo elas: singlet/singlet; singlet/contig; interna a região de um contig ou em diferentes contigs. Além dos clones, muito dos genes terão sequiências incompletas, devido às regiões do genoma ainda não sequienciadas, chamadas gaps (buracos). Entretanto, para as buscas aos clones ótimos em genomas parciais, foram desenvolvidas regras específicas para tratar cada situação em particular. Tais regras foram primeiramente elaboradas implementadas na primeira versão da ferramenta de seleção de clones ótimos, OC Identifier tool (Cantão et al., 2007).

Uma vez que a atenção estava voltada a uma rápida seleção de clones e aos resultados dos experimentos biológicos, as regras de seleção foram implementadas sem o uso de abordagens computacionais avançadas, cujo desenvolvimento demandaria maior tempo e dedicação para serem desenvolvidas. Sendo assim, todas as regras foram definidas no código fonte da aplicação, na qual necessita de maiores esforços para realizar alterações nas regras, como também no controle do fluxo do sistema.

Com os resultados obtidos nos experimentos biológicos validados, as regras de seleção de clones foram ampliadas e aperfeiçoadas para serem usados em novos organismos e projetos. Desse modo, durante o processo de expansão, todas as regras foram mapeadas em expressões algébricas e o fluxo do sistema passou a ser controlado por meio de um arcabouço algébrico. A versão algébrica da ferramenta de seleção de clones OCI 2 (Cantão et al., 2009) está preparada para a seleção de clones em genomas procariotos parcialmente ou completamente seqüenciados, como também para projetos de metagenomas. 


\subsection{Regras de seleção de clones}

As regras de seleção de clones estão divididas em duas versões, sendo elas: genomas parciais e completos. Em genomas parciais, para realizar a seleção dos clones, quatro regras com abordagens diferentes foram desenvolvidos. Essa divisão foi necessária, devido às diferentes situações que os clones são encontrados nos genomas parciais, sendo eles:

- Mesmo contig - clones localizados no mesmo contig;

- Contigs diferentes-clones localizados em contigs diferentes;

- Singlet/contig - uma das seqüências do clone localizada em contig e a outra como singlet;

- Singlet/singlet - ambas as seqüências dos clones fora dos contigs.

Nas buscas aos clones localizados nos mesmos contigs, somente são analisados aqueles que estão com as duas seqüências amplificadas pelos oligonucleotídeos universais presentes na região interna de um contig. Durante o processamento é analisado as posições inicias e finais de todos os clones e verificam quais deles condizem com os parâmetros passados pelas regras. Em um exemplo de seleção, cuja regra seja selecionar clones que contenham 1 ORF, caso a região do clone localizado na seqüência do contig conter apenas 1 ORF, o clone será selecionado como ótimo, caso contrário, será descartado pela análise. Somente os clones que satisfazem a todos os atributos de seleção são considerados como ótimos (ver figura 7.1).

Nas buscas aos clones localizados em diferentes contigs, somente são analisados aqueles que contêm cada seqüência amplificada pelos oligonucleotídeos universais presente em diferentes contigs. Durante o processamento é verificado as posições iniciais de cada sequiência dos clones nos contigs e, ao final das análises, o clone será considerado ótimo caso as regiões representadas pelas seqüências localizadas em cada contig satisfaçam aos atributos passados pelas regras. Em um exemplo de seleção, cuja regra seja selecionar clones que contenham 1 ORF, cada região do clone localizado em diferentes contigs é analisado e, se ambas as regiões conterem $1 \mathrm{ORF}$, e as ORFs forem às mesmas, isto é, $1 \mathrm{ORF}$ interrompida por um gap entre os contigs, o clone será selecionado como ótimo, caso contrário, o clone será descartado (ver Figura 7.1).

Quando a seleção ocorre aos clones que possuem uma de suas seqüências externa ao contig, isto é, identificada como singlet, o programa verifica se a região do clone interno ao contig e sua seqüência externa (singlet) satisfazem aos atributos passados para a seleção. Em 
um exemplo, cuja regra seja selecionar clones que contenham $1 \mathrm{ORF}$, se as regiões dos clones localizados nos contigs e singlets conterem $1 \mathrm{ORF}$, e as ORFs forem às mesmas, isto é, ORF interrompida por um gap entre o contig e o singlet, o clone será selecionado como ótimo (ver Figura 7.2).

Para finalizar as regras de seleção em genomas parciais, o último processo ocorre quando ambas as seqüências dos clones estão localizadas externas aos contigs, nas seqüências dos singlets. Nesse caso, é verificado se os atributos de seleção estão presentes nas duas seqüências dos clones. Em um exemplo de seleção, cuja regra seja selecionar clones que contenham 1 ORF, no caso de ambas as seqüências amplificadas pelos oligonucleotídeos universais conterem ORFs, e as ORFs forem às mesmas, o clone será selecionado como ótimo (ver Figura 7.3).

Diferente dos genomas parciais, os genomas completos possuem todas as posições dos clones, ORF, RNAr, RNAt entre outras, já definidas na seqüência final do genoma. Contudo, o processo de seleção se equivale às condições dos clones localizados nas seqüências dos mesmos contigs em genomas parciais. Sendo assim, a base principal das regras usadas na seleção é o mesmo empregado nas análises dos clones localizados nos contigs internos em genomas parciais (ver Figura 7.4).

No intuito de exemplificar as regras de seleção de clones, são apresentadas quatro situações relevantes nos quais os clones aparecem em genomas parciais e completos e, em seguida, alguns processos de seleção aos clones ótimos são descritos.

\subsubsection{Clones em genomas parciais}

Nos projetos em genomas parciais, alguns fatores influenciam e dificultam o processo de seleção dos clones ótimos. Tais fatores podem ser definidos como: falta de seqüenciamento de várias regiões do genoma (gaps), existência de genes com seqüenciamento incompletos, clones com seqüências iniciais separadas em diferentes contigs ou fora deles (singlets), dificuldades na predição gênica devido às regiões de seqüências incompletas no genoma. Tais fatores dificultam a identificação dos clones em genomas parciais, porém, não impedem suas seleções. 


\subsubsection{Clones localizados nos mesmos contigs, ou contigs separados}

O exemplo ilustrado pela Figura 7.1 apresenta duas seqüências de contigs, três seqüências de clones localizadas no interior de cada contig e três ORFs diferentes.

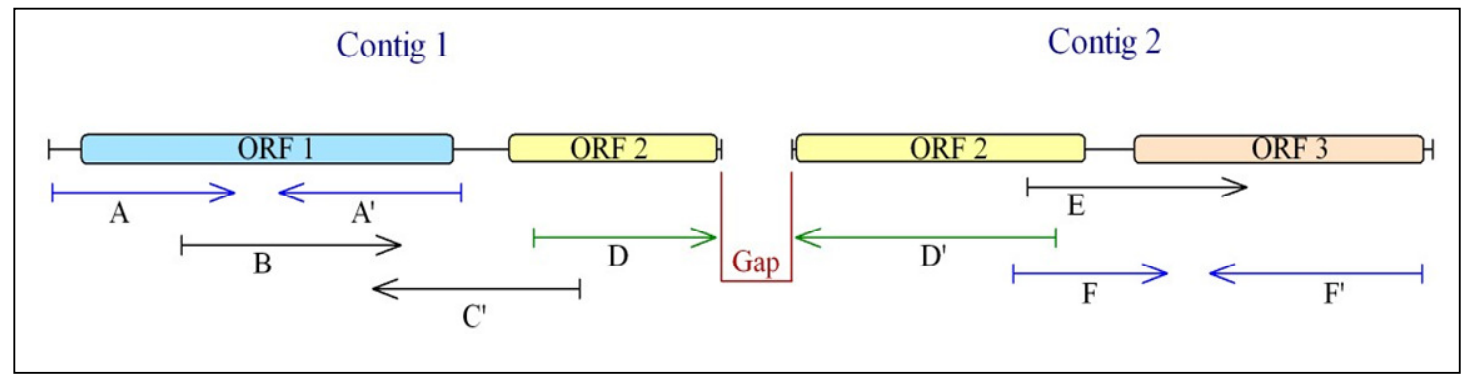

Figura 7.1 - Esquema das posições das ORFs e dos clones dentro dos contigs. No "Contig 1" e "Contig 2", são duas ORFs inicialmente identificadas. Mesmo com um gap entre os dois contigs, identificou-se que a "ORF 2" do "Contig 2" é a mesma e continuação da "ORF 2" do "Contig 1". O clone ótimo que seleciona a "ORF 2" é o clone $D$, enquanto que o clone ótimo que seleciona a "ORF 1 "é o Clone $A$

Para o processo de seleção dos clones ótimos da Figura 7.1, as situações dos clones são descritas a seguir.

- Clone A - As duas seqüências amplificadas pelos óligos universais forward (A) e reverse (A') estão localizados no "Contig 1" e a seqüência da "ORF 1" está localizada internamente ao clone. Para esse clone, sua localização no projeto é definida como: "Contig/Contig Interno", ou pela abreviação "CCI", isto é, clones com seqüências localizados na mesma seqüência do contig.

- Clone D - A sequiência amplificada pelo óligo forward (D) encontra-se no “Contig 1”, enquanto que a seqüência amplificada pelo óligo reverse (D') está localizada no "Contig 2". Mesmo com o gene não seqüenciado completamente, foi possível identificar que esse clone representa a "ORF 2". Para esse clone em especial, sua localização no projeto é definida como "Contig/Contig Externo", ou pela abreviação "CCE", isto é, clones com seqüências localizados em diferentes contigs.

- Clone F - As duas seqüências amplificadas pelos óligos universais forward e reverse estão localizados no “Contig 2". Nesse caso, a sequiência do óligo 
forward (F) representa a "ORF 2", enquanto que a seqüência do óligo reverse (F') representa a “ORF 3". Portanto, esse clone contém 2 ORFs em sua seqüência completa.

- Clones B, C e E - Esses três clones contêm apenas uma das seqüências, localizada internamente aos contigs. Isso pode acontecer quando clones que apresentam baixa qualidade de seqüenciamento não se juntam aos contigs durante a montagem do genoma, ou mesmo, uma das seqüências pode estar localizada como singlet.

Com base nos clones e ORFs disponíveis para análises na Figura 7.1, três perguntas foram elaboradas para a seleção de clones e seus respectivos resultados são apresentados.

1) Selecionar clones que contenham a seqüência de 1 ORF e localizados no mesmo contig.

Selecionado: Clones A.

2) Selecionar clones com 1 ORF, seqüência da ORF interna ao clone e em contigs separados.

Selecionado: Clone D.

3) Selecionar clones que representam a "ORF 3", localizados na mesma seqüência do contig.

Selecionado: Clone F.

Das perguntas elaboradas, a primeira selecionou o clone $A$, pois é o único que contém as duas seqüências do clone (B e B') interno ao contig e seleciona 1 ORF. Na segunda pergunta, o clone $D$ foi selecionado, pois o clone está localizado em diferentes contigs e internamente a seqüência da “ORF 2".

Para finalizar, a terceira pergunta é voltada para a seleção de clones que representem a “ORF 3", não importando se o mesmo contém a seqüência de outras ORFs. Desse modo, o clone identificado pela letra $F$ foi selecionado como ótimo. 


\subsubsection{Clones localizados nas seqüências dos contigs e singlets}

Quando o genoma se encontra em fase de seqüenciamento, o número de contigs montados pode chegar a milhares; o mesmo ocorre com as seqüências dos clones que ainda não estão dentro dos contigs, denominados singlets. Sendo assim, o exemplo ilustrado pela Figura 7.2 apresenta as seqüências dos clones $A, A^{\prime}, \mathrm{B}$ e $C^{\prime}$, sobrepondo e formando o “Contig 19”. A seqüência $B$ ' amplificada pelo óligo universal reverse do clone $B$ está localizada externamente ao contig e é identificada como singlet.

Neste exemplo, foram identificadas 2 ORFs diferentes, sendo a "ORF 7" localizada na seqüência do "Contig 19" e a "ORF 8", separada por um gap entre a sequiência do clone B' e o "Contig 19".

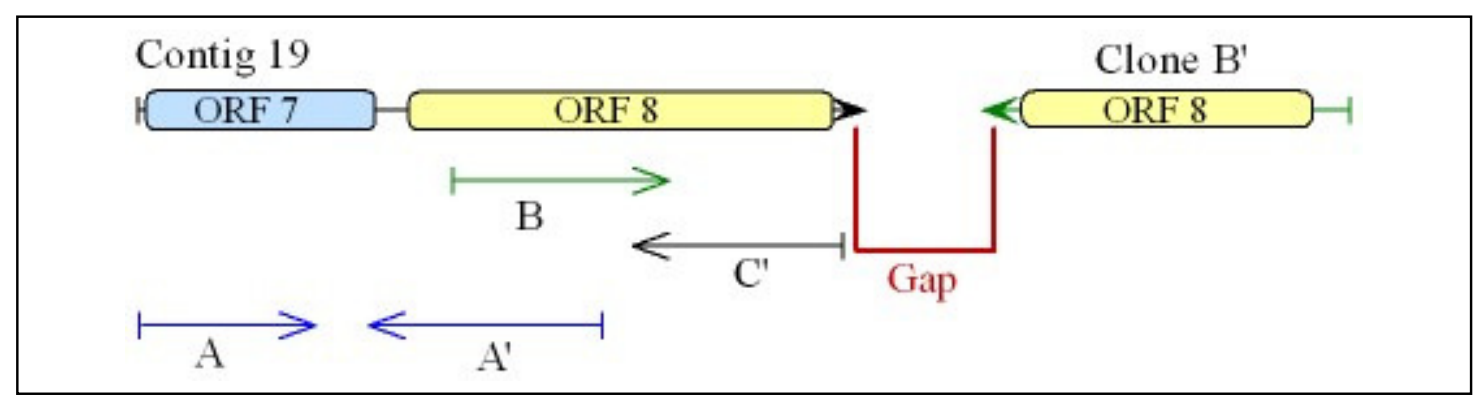

Figura 7.2 - O clone B representa a "ORF 8", sendo considerado como ótimo por conter apenas 1 ORF. Nesse exemplo, a seqüência amplificada pelo óligo forward do clone está localizada internamente ao "Contig 19", enquanto que a sequiência reversa (B') aparece como Singlet

Com base nos clones e ORFs ilustrados na Figura 7.2, uma pergunta é elaborada para exemplificar a seleção do clone ótimo.

1) Selecionar clones que contêm a sequiência de 1 ORF e estejam localizados nas seqüências de contigs e singlets.

Selecionado: Clone B.

O clone ótimo selecionado foi o clone $B$, pois somente ele se encontra na situação identificada como contigs e singlets e representa a seqüência da "ORF 8". 


\subsubsection{Clones localizados como singlets}

A Figura 7.3 apresenta as sequiências amplificadas pelos óligos universais forward (A) e reverse (A') do clone $A$. Nesse caso, as duas sequiências do clone estão fora dos contigs e são classificadas como singlets. Na seqüência do clone $A$, foi identificada a sequiência da mesma “ORF 1" interrompida por um gap.

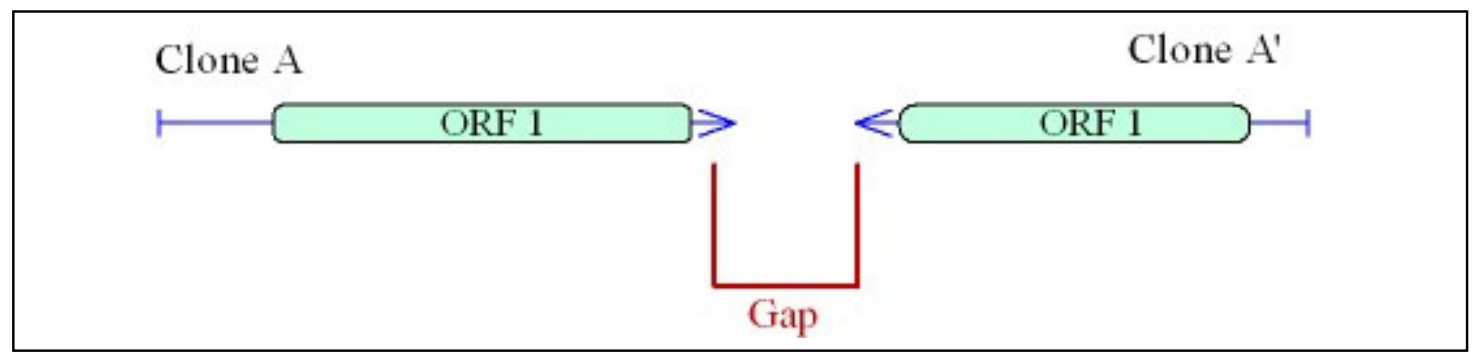

Figura 7.3 - As seqüências desse clone estão identificadas como singlets, pois estão fora dos contigs e possuem a mesma ORF identificada nas duas seqüências

Portanto, se a pergunta elaborada for para selecionar clones localizados nas sequiências dos singlets e que contenham 1 ORF, esse clone será selecionado como ótimo.

\subsubsection{Clones em genomas completos e metagenômicos}

Quando as buscas ocorrem em genomas completos, os genes já foram identificados e as posições dos clones determinados na seqüência do genoma. Dessa forma, as buscas aos clones ocorrem na seqüência final do genoma.

Sendo assim, a Figura 7.4 ilustra os clones identificados pelas letras de $A$ a $E$, e a identificação de 3 ORFs, todas localizadas internamente a uma região do genoma cromossomal.

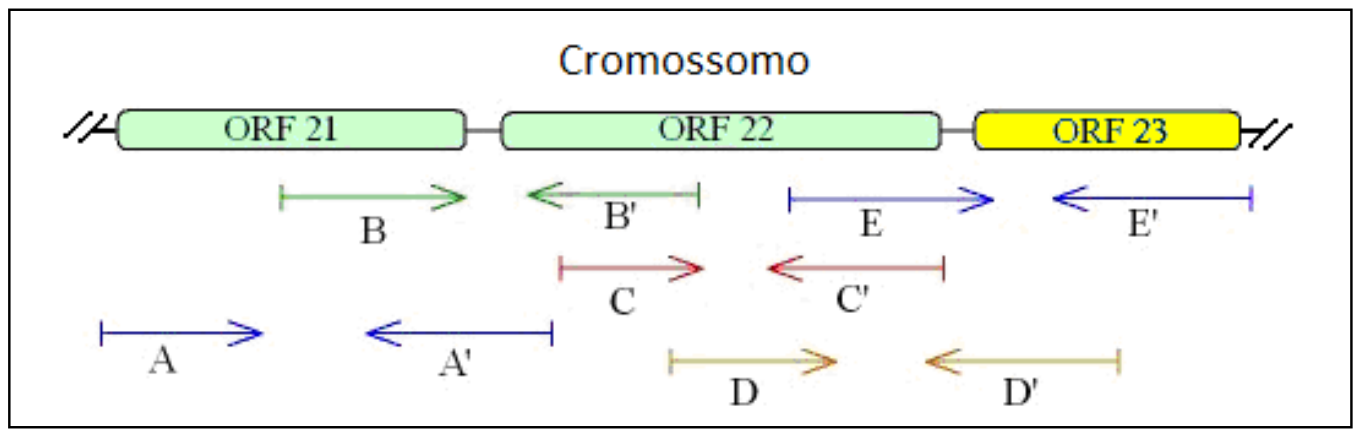

Figura 7.4 - Clones dispostos na seqüência final do genoma cromossomal 
O processo que seleciona os clones nesta condição, contém as mesmas bases ao apresentado na seleção de clones ótimos em genomas parciais na condição de "clones localizados na mesma seqüência do contig”. Porém, a diferença é que em genomas completos, as análises são realizadas apenas na sequiência do genoma, enquanto que em genomas parciais, as análises são realizadas em todos os contigs produzidos pelo projeto.

Com base nos clones e ORFs ilustrados na região do genoma apresentado na Figura 7.4, uma pergunta é elaborada para exemplificar a seleção do clone ótimo.

1) Selecionar clones que contenha seqüência de $1 \mathrm{ORF}$; Selecionado: Clone $C$.

Neste exemplo, o clone $C$ é o único selecionado, pois os demais clones $A, B, D$ e $E$ contém a seqüência de 2 ORFs. 


\section{Capítulo 5}

\section{Implementação das ferramentas}

Na primeira versão da ferramenta de seleção de clones, o controle das regras foi mapeado no código fonte da aplicação. Uma vez mapeado, as alterações para se adaptarem as novas condições de pesquisas são realizadas via código de programação. Para ganhar maior poder de expressividade e tornar as alterações das regras de seleção flexíveis, todas as regras foram mapeadas em expressões algébricas e passaram a ser controladas por meio de um arcabouço algébrico no $O C I 2$.

Para apresentar o ganho de eficiência no sistema mapeado e controlado por expressões algébricas, é realizada uma comparação entre as versões da ferramenta OC Identifier e $O C I 2$.

\subsection{Gerenciamento do fluxo do sistema via código de programação}

No controle do fluxo do sistema, realizado por meio de código de programação, todas as regras elaboradas e a ordem de suas execuções são expressas dentro do código fonte do aplicativo. Desse modo, uma vez que novas regras sejam criadas, a sua inserção implica diretamente na alteração do código do sistema.

Para demonstrar o controle do fluxo do sistema por meio de código de programação, o exemplo abaixo contém regras para selecionar clones nas seguintes condições: clones localizados em diferentes contigs; ORFs únicas e localizadas internamente às seqüências dos clones.

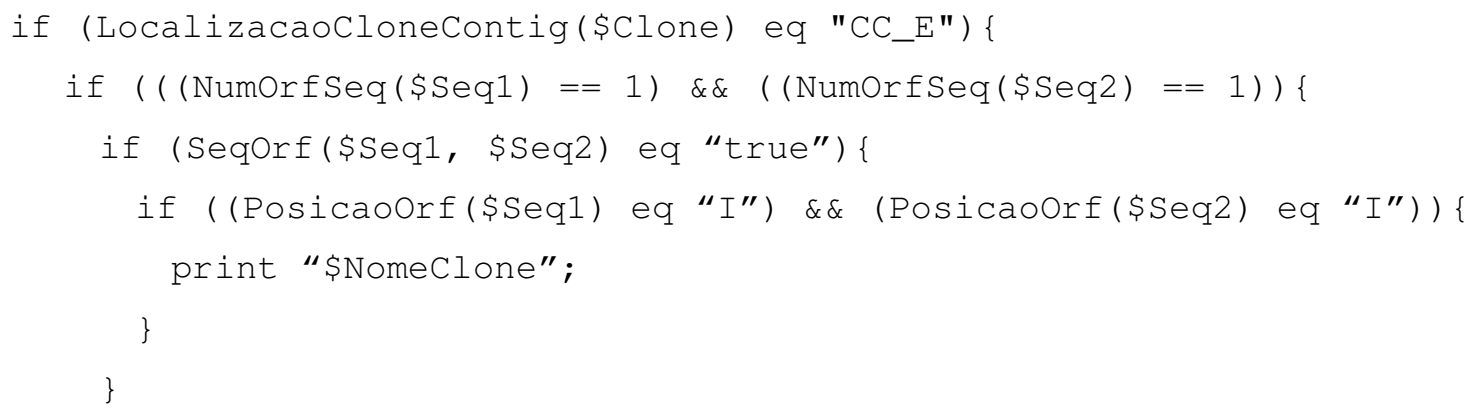


Para esse exemplo, foram criadas quatro funções, sendo elas: LocalizacaoCloneContig; NumOrfSeq; SeqOrf e PosicaoOrf. O primeiro processamento é efetuado pela função LocalizacaoCloneContig, que recebe como parâmetro o nome do clone e verifica se o retorno da função é "CC_E”, isto é, seqüências dos clones localizados em diferentes contigs. Se o resultado da execução condicional for verdadeiro, a função NumOrfSeq será chamada para dar continuidade ao processamento, caso contrário a análise será finalizada.

O segundo processamento ocorre com a verificação da quantidade de ORFs localizadas nas seqüências dos clones pela função NumOrfSeq, e retorna o número de ORFs encontrado em cada sequiência. Sendo assim, se alguma seqüência contiver mais de 1 ORF, ou nenhuma, o processamento será encerrado, caso contrário a próxima função será chamada. A próxima análise é feita pela função SeqOrf, cujo objetivo é validar se as ORFs localizadas nos clones, separados por gaps, são as mesmas. Se o retorno da análise for o valor verdadeiro (true), então o clone contém 1 ORF e a próxima função será executada. Caso contrário, o clone conterá 2 ORFs diferentes e o processamento será encerrado.

O último processamento ocorre com a função PosicaoOrf, que verifica se o início do clone está interno ("I") à seqüência da ORF. Se o resultado da função for verdadeiro, o nome do clone será impresso, caso contrário a execução será finalizada.

Uma vez programado o fluxo do sistema, qualquer modificação, inserção ou a remoção de novas regras, ou mesmo a alteração na ordem de execução das regras implica diretamente na reformulação do código fonte do sistema.

\subsection{Gerenciamento do fluxo do sistema por linguagem algébrica}

No controle do fluxo do sistema, realizado por meio de linguagem algébrica, todos os processos e a ordem de sua execução são controlados fora do código da aplicação. Dessa maneira, as mudanças implicam somente na alteração da expressão algébrica que controlam as execuções dos processos.

Com o propósito de mostrar a diferença entre o controle de fluxos dos sistemas pelo modo tradicional e pela abordagem algébrica, o mesmo processo de seleção usado na seção 
anterior é mapeado em expressão algébrica e NPDL. Por questão de visualização, os nomes das regras serão alterados para as letras iniciais de cada regra da seguinte maneira: a regra LocalizacaoCloneContig é renomeada para LCC; NumOrfSeq para NOS; SeqOrf para SO e por fim a Regra PosicaoOrf é renomeada para $\boldsymbol{P O}$. Para dar continuidade à execução das regras e imprimir os clones selecionados, duas ações foram criadas, sendo elas: $\boldsymbol{G} \boldsymbol{O}$ (Go On) e PRI (Print).

Considerando a lista de operadores da NPDL $\{\bullet,+, \|, \%\}$, regras $\{\boldsymbol{L C C}, \boldsymbol{N O S}, \boldsymbol{S O}, \boldsymbol{P O}\}$ e as ações atômicas $\{\boldsymbol{G O}, \boldsymbol{P R \boldsymbol { I }}\}$ é possível mapear o processo de seleção de clones para se comportarem da mesma forma que o exemplo apresentado na seção 5.1.

Desse modo, o processo de seleção da seção anterior é mapeado para a seguinte expressão algébrica:

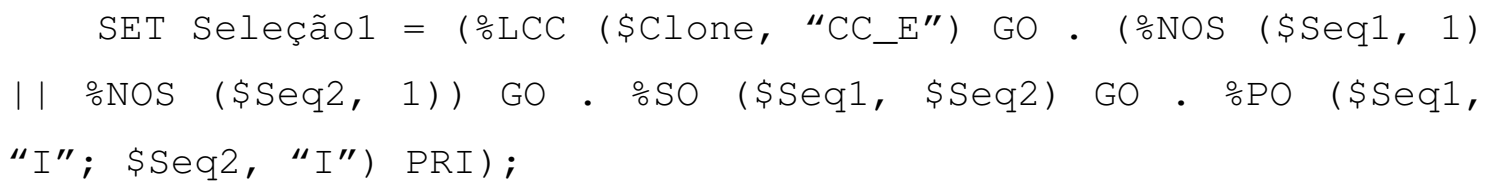

$\mathrm{Na}$ expressão algébrica atribuída ao processo Seleçãol, a primeira execução ocorre com uma chamada de execução a regra $\boldsymbol{L C C}$ (NumOrfSeq), que recebe como parâmetros de entrada \$Clone e CC_E separados por vírgula, e aguarda um valor booleano (verdadeiro ou falso) ao final do seu processamento. Caso as seqüências dos clones estejam localizadas em diferentes contigs, a regra retornará um valor verdadeiro, e a ação silenciosa $\boldsymbol{G} \boldsymbol{O}$ (Go On) será liberada para execução. Devido à sua definição, a ação $\boldsymbol{G} \boldsymbol{O}$ permite dar continuidade à execução do restante da expressão. A execução seqüencial indicada pelo operador composição seqüencial $(\bullet)$ passa a execução para as duas próximas regras, NOS (NumOrfSeq), na qual as execuções estão controladas pelo operador composição paralelo ( II ), e possibilita a execução das regras simultaneamente.

Ao final da execução das regras NOS, caso as duas seqüências do clone contenham 1 ORF, os valores retornados das regras serão verdadeiros, e, por conseguinte, a ação $\boldsymbol{G} \boldsymbol{O}$ passará à execução adiante. Em seguida, a regra SO (SeqOrf) inicia seu processamento, analisa as seqüências das ORFs e retorna um valor verdadeiro caso as sequiências sejam as mesmas. Por fim, a ação $\boldsymbol{G} \boldsymbol{O}$ passa adiante a execução da regra $\boldsymbol{P O}$ (PosicaoOrf), cuja função é verificar a posição das ORFs em relação aos seus clones. Nesse exemplo, caso a seqüência 
da ORF esteja localizada internamente ao clone, a ação PRI imprimirá o nome do clone selecionado. Pelo fato de todas as regras estarem encadeadas pelo operador condicional $(\bullet)$, caso um valor falso seja retornado por alguma delas, a execução do programa é finalizado.

Uma vez que o fluxo do sistema é controlado fora do código da aplicação, o procedimento de remoção/inserção de novas regras, assim como a alteração na ordem de suas execuções, torna-se um processo totalmente dinâmico. Dessa forma, as alterações no fluxo do sistema são realizadas simplesmente recompondo a ordem da expressão algébrica para o novo conjunto de regras. No exemplo a seguir, a ordem de execução das ações $\boldsymbol{S} \boldsymbol{O}$ e $\boldsymbol{P O}$ foi alterada em relação à seleção original.

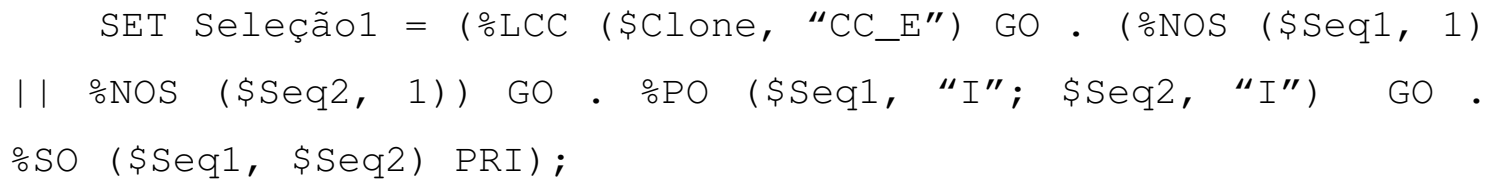

Essa nova expressão, apesar de oferecer um novo comportamento para o sistema, não demanda alteração no programa, uma vez que o OCI 2 está preparado para executar expressões da álgebra de processos.

Por meio da álgebra de processos, é possível que as regras de seleção sejam definidas em diferentes projetos e os mesmos executados paralelamente. Desse modo, é possível determinar que os clones ótimos de um projeto sejam todos aqueles que satisfizerem as regras definidas nos processos Seleçãol e Seleção2. Para isso, esse novo processo será definido da seguinte forma:

\section{SET Seleção3 = (Seleção1 || Seleção2);}

Nessa expressão, cada um dos processos pode ser executado de forma simultânea e, ao final, todos os clones selecionados serão atribuídos ao processo Seleção3.

Portanto, mapear o fluxo do sistema por meio de abordagem algébrica propicia maior flexibilidade ao sistema, consistência na criação de regras, precisão na geração do código gerado para controlá-las e, ainda, com a vantagem de alterar o fluxo do sistema sem implicar na reestruturação do código fonte do sistema. 


\subsection{Definição das regras e ações que compõem o processo de seleção dos clones no $O C I 2$}

A álgebra de processos é usada no controle do fluxo de sistema no OCI 2 e gerencia a execução de todas as regras e ações da ferramenta. Antes de descrever a expressão algébrica, primeiro será definida as regras e ações que compõem o sistema.

As regras e ações criadas para a seleção dos clones ótimos são definidas a seguir:

- SCBT (SelectClonesByTarget) - Responsável pela seleção inicial dos clones pelo tipo de Alvo. Por exemplo, gene, RNAr ou região ITS (do inglês Internal Transcribed Spacer).

- SCBI (SelectClonesById) - Responsável pela seleção inicial dos clones, baseada em seus identificadores (Ids). Por exemplo, o código de identificação do gene no genoma.

- AOT (AnalysisOverlapTarget) - Verifica a possibilidade de haver sobreposição de outros alvos no clone, isto é, seqüências de outros alvos no clone.

- PCT (PositionCloneTarget) - Verifica a posição do clone em relação ao seu alvo. Por exemplo, verifica se o clone está interno à seqüência do gene.

- DCT (DistanceCloneTarget) - Verifica a distância do início do clone ao início do seu alvo.

- CT (CoverageTarget) - Verifica quantas bases do clone representam a sequiência alvo.

- PR (PromoterRegion) - Verifica se um clone contém uma região promotora.

- DOC (DisplayOptimalClones) - Ação que mostra, ao final do processamento da regra, os clones que foram selecionados.

- DOW (Download) - Ação que cria um arquivo com os resultados do processamento das regras e disponibiliza para download.

- GO (Go on) - Ação que permite dar continuidade à avaliação da expressão algébrica.

- $\quad$ END - Ação que sinaliza o término do processo.

Uma vez que a versão do OCI 2 é controlada por meio de linguagem algébrica, o usuário passa a se preocupar apenas com a elaboração das regras e suas ações, pois, nessa abordagem, o código que controla os fluxos do sistema é gerado automaticamente.

Desse modo, os processos de seleção dos clones ótimos são compostos por um conjunto de regras e ações atômicas. As regras podem ser definidas como as atividades que 
desempenham um processamento específico e produzem como resultado um valor Booleano ao final da execução, enquanto as ações podem ser definidas como método que executa uma tarefa pré-estabelecida.

\subsubsection{Interpretação das regras e mapeamento em álgebra de processos}

A seleção de clones se baseia na presença do alvo que se pretende estudar na seqüência dos clones que compõem o genoma. As regras de seleção de clones SCBT e SCBI contêm as informações para a execução do primeiro processamento dos dados. As informações básicas são expressas como atributos de entrada das regras. As regras definidas para as versões da ferramenta em genomas completos e parciais são apresentadas abaixo:

- Os parâmetros usados pelas regras SCBT (SelectClonesByTarget) e SCBI (SelectClonesById):

- TypeGenome - clones do genoma ('Cromossomal' ou 'Plasmidial') a ser analisado;

- TypeTarget - tipo do alvo a ser estudado e localizados nas seqüências dos clones, sendo eles: as $O R F s$ (classificadas como os possíveis genes do genoma); rRNA são as seqüências de RNA ribossomal e ITS são as regiões localizadas entre duas regiões de RNA ribossomal no genoma;

- TypeClone - tipo do clone que contém o alvo a ser estudado, ou seja, shotgun ou cosmídeo;

- OverlapOtherTarget - indica se o clone que contém o alvo desejado possui parte de outra seqüência.

- Atributos específicos da regra SCBT:

- NumberTargetClone - número de alvos para cada clone selecionado;

- SizeTarget - valor que restringirá o tamanho dos alvos a serem analisados;

- FunctionCategory - categoria funcional que restringirá as análises apenas aos genes que pertencem a uma categoria funcional em questão. 
Caso os valores dos atributos não sejam informados, tais características serão ignoradas durante a seleção dos clones.

- Atributo específico da regra SCBI:

- IdsTarget - seleciona apenas os clones que contenham os alvos especificados por seus identificadores.

Atributo específico das regras SCBI e SCBT adicionadas à versão da ferramenta em genomas parciais:

- regras SCBT e SCBI:

- LocalizationClones - em um genoma parcial, os clones que são analisados estão localizados em uma das quatro situações, sendo elas:

- As duas sequiências do clone (forward e reverse) localizadas no mesmo contig;

- As duas sequiências do clone localizadas em contigs diferentes;

- Uma seqüência do clone localizada em contig e a outra como singlet;

- As duas seqüências do clone como singlet.

Definidos todos os atributos de entrada para as regras SCBT e SCBI, a seguir um exemplo de como o OCI 2 mapeia o processo de seleção de clones de um genoma completo em álgebra de processos por meio da linguagem NPDL.

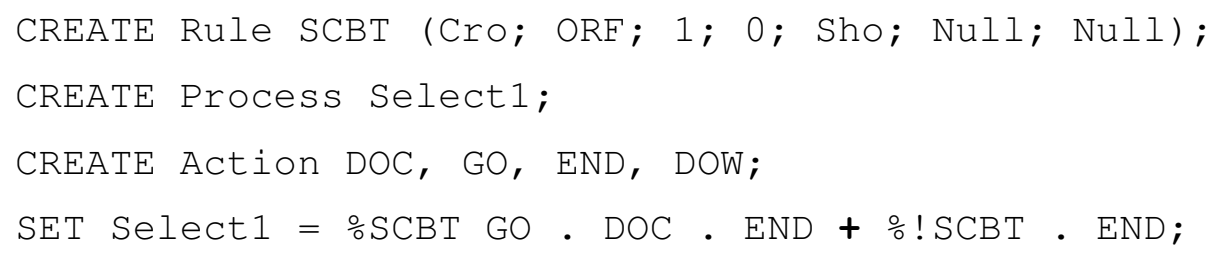

Antes de definir a expressão algébrica que controlará a execução do processo, é necessário criar as ações, as regras e os processos, por meio do comando CREATE da linguagem NPDL. Em seguida, a expressão algébrica é atribuída a um processo pelo comando SET.

No exemplo do processo Select1, a regra SCBT foi definida para selecionar clones do tipo Shotgun que contenham 1 ORF na seqüência do genoma cromossomal, e que não haja 
seqüência de outra ORF no clone. $O$ tamanho da ORF e sua categoria funcional não serão usados como parâmetros discriminatórios. No final do processamento da regra SCBT (SelectClonesByTarget), se algum clone for selecionado, uma resposta verdadeira é retornada e habilitará a execução da ação GO (Go on), que dará continuidade à execução do processo que é então passada para a ação DOC (DisplayOptimalClones). A ação DOC mostra os clones selecionados e, em seguida, a ação END é chamada e finaliza o processo. Se na execução da regra SCBT retornar um valor falso, a ação END é executada para finalizar o processo.

Caso o processo Select1 seja aplicado na situação ilustrada pela Figura 8, os seguintes clones seriam selecionados como ótimos:

- Clones: A e C $\rightarrow$ ORF 1;

- Clone: D $\rightarrow$ ORF 2;

- Clone: $\mathbf{G} \rightarrow$ ORF 3 .

A Figura 8 ilustra a situação em que as seqüências dos clones e cosmídeos se encontram na seqüência do genoma.

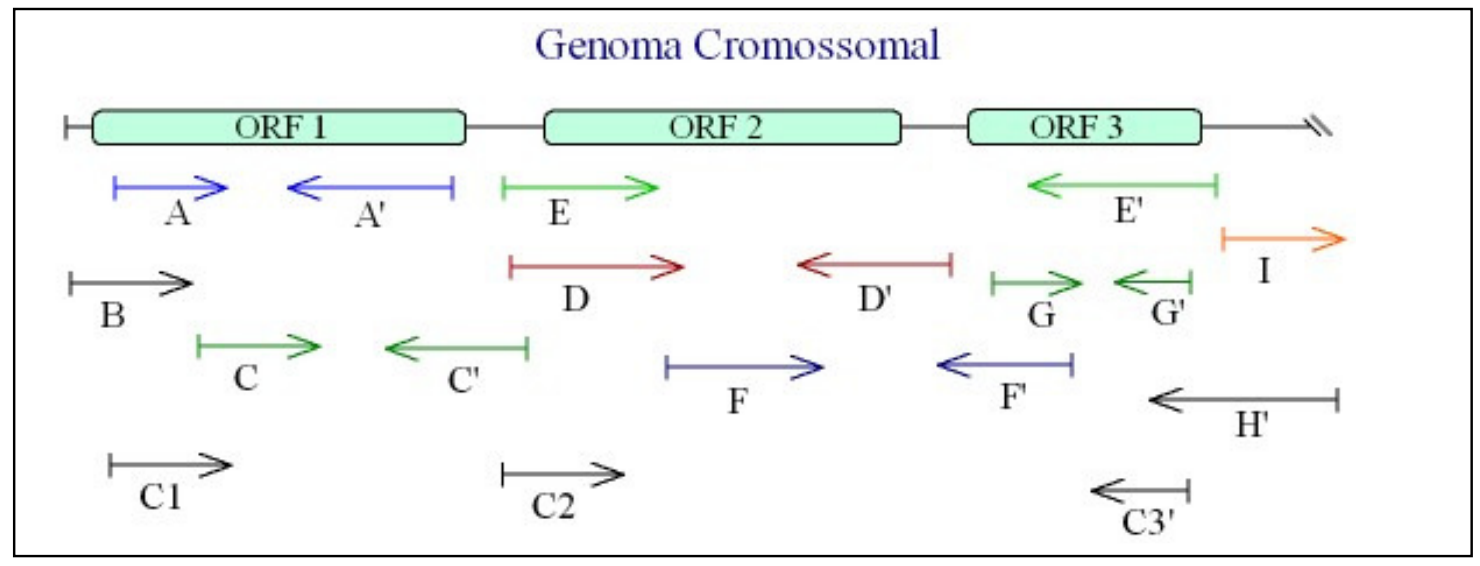

Figura 8 - Representa um genoma completo e contém as seqüências das ORFs de 1 a 3, os clones são identificados pelas letras $A$ a $H$, e as seqüências dos cosmídeos identificadas pela letra $C$, seguida de um número, por exemplo, $C 1, C 2$. Os clones e cosmídeos são formados pelas sequiências forward e reverse, sendo que a seqüência reverse é identificada por apóstrofo após seus nomes, exemplo, $A$ ', $D^{\prime}, C 3^{\prime}$. Nem sempre as duas sequiências do clone estão presentes na montagem, como é o caso dos clones $B, H$ e $I$.

\section{- Regra SCBI}

Exemplo do processo de seleção de clones pelos códigos de identificação (Ids) em genoma completo, mapeado em álgebra de processos. 


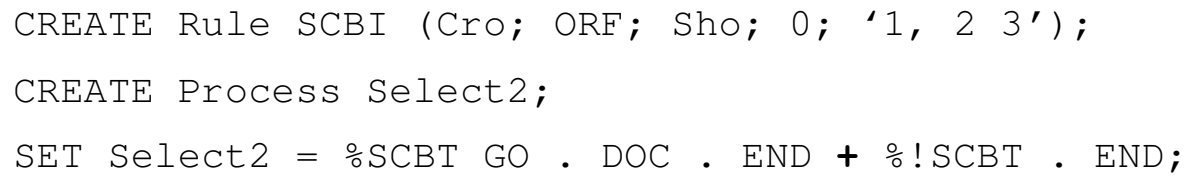

Nesse segundo exemplo, apenas a regra SCBI e o processo Select2 serão criados, pois as ações DOC, GO e END já foram criadas anteriormente. O processo Select2 executa a regra SCBT, no qual especifica a seleção de clones do tipo shotgun que contenham a ORF 1, ou ORF 2 e 3, na sequiência dos clones no genoma cromossomal. Porém, não será permitida a presença de bases de outra ORF no clone.

Caso o processo Select2 seja aplicado na situação ilustrada pela Figura 8, os seguintes clones seriam selecionados como ótimos:

- Clones: A e C $\rightarrow$ ORF 1;

- Clones: E e F $\rightarrow$ ORF 2 e 3.

Após a seleção inicial dos clones, as próximas regras têm como objetivo verificar se os clones selecionados atendem as características impostas pelo processo. Desse modo, a cada atividade processada, mais refinada se tornam os resultados obtidos. A seguir, são descritas as demais regras oferecidas que compõem o processo de seleção de clones ótimos.

\section{- Regra AOT (AnalysisOverlapTargets)}

- OverlapTarget - um fragmento de um novo alvo (ORF, rRNA ou tRNA) que o clone poderá ter em sua sequiência, além do alvo principal da busca;

- OverlapBases - tamanho máximo em nucleotídeos que um diferente alvo poderá estar presente na seqüência do clone.

Exemplo do processo de seleção de clones mapeados em álgebra de processos:

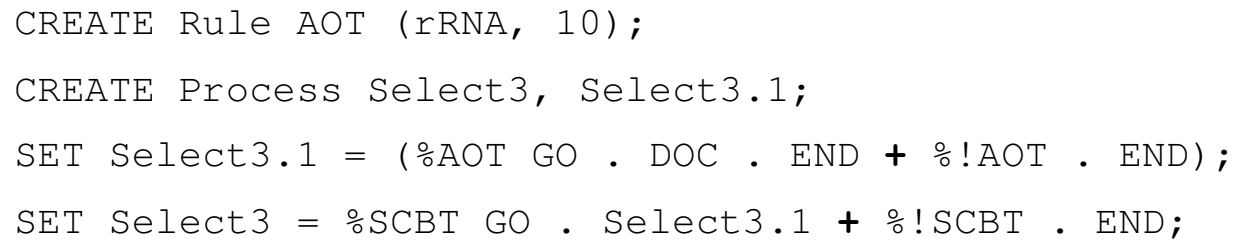


O exemplo acima é composto de dois processos, Select3 e Select3.1, sendo que o processo Select3, reutiliza a mesma regra definida anteriormente para SCBT (SelectClonesByTarget) no processo Select1. O primeiro processo a ser executado é o Select3, e após a execução da regra SCBT se algum clone for selecionado, a ação GO libera a execução do processo Select3.1. Caso contrário, a ação END finalizará o processo. O processo Select3.1 executa a regra AOT (AnalysisOverlapTarget), com a especificação de que, além do alvo principal (ORF), esse clone poderá ter um fragmento de, no máximo, 10 nucleotídeos de uma seqüência de rRNA.

Caso o processo Select3, definido acima, seja aplicado na situação ilustrada pela Figura 9, os seguintes clones seriam selecionados como ótimos:

- Clones: B e C $\rightarrow$ ORF 4;

- Clones: E e $\mathbf{F} \rightarrow$ ORF 5.

A Figura 9 ilustra uma situação em que aparece uma seqüência de RNA ribossomal 5S e duas ORFs na seqüência do genoma.

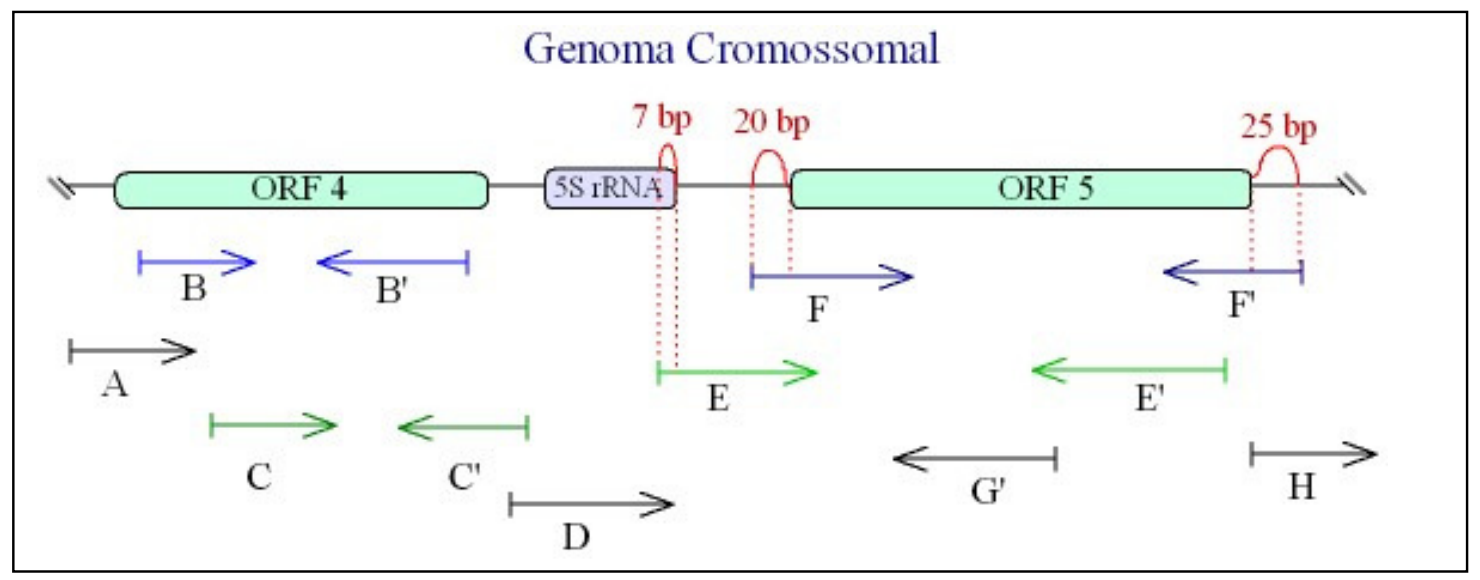

Figura 9 - Representa um fragmento de um genoma com duas ORFs, uma seqüência de "rRNA 5S" e 8 clones identificados pelas letras $A$ a $H$. O clone $B$ encontra-se interno à "ORF 4", enquanto que o clone $F$ está localizado externamente à "ORF 5". O clone $E$ representa a "ORF 5" e contém 7 bases da sequiência do "rRNA 5S" na seqüência no sentido forward

\section{- Regra PCT (PositionCloneTarget)}

- PositionCloneTarget - os clones selecionados podem estar localizados "I" dentro (Inside) ou "O" - fora (Outside) dos alvos. 
Exemplo do processo de seleção de clones mapeados em álgebra de processos:

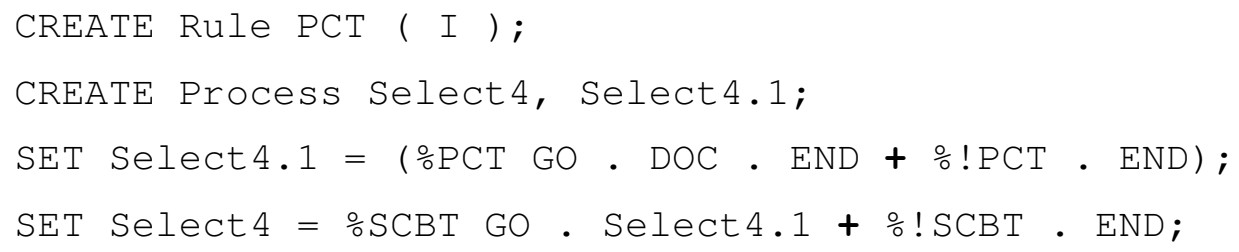

Após a execução da regra SCBT no processo Select4, se algum clone for selecionado, a ação GO libera a execução do processo Select4.1, caso contrário, a ação END finalizará o processo. O processo Select4.1 executa a regra PCT (PositionCloneTarget), no qual especifica que os clones obrigatoriamente estarão localizados internamente nas sequiências dos alvos.

Caso o processo Select4, definido acima seja aplicado na situação ilustrada pela Figura 9, o seguinte clone seria selecionado como ótimo:

- Clone: B $\rightarrow$ ORF 4 .

\section{- Regra DCT (DistanceCloneTarget)}

- DistanceCloneTarget - os clones que contêm o alvo em sua sequiência iniciam a uma distância maior ou igual, ou menor ou igual (Large or Equal "L" ou Less or Equal "l"), a um determinado número de nucleotídeos dos seus alvos;

- NumberBases - distância que o clone tem que iniciar do seu alvo.

Exemplo do processo de seleção de clones mapeados em álgebra de processos:

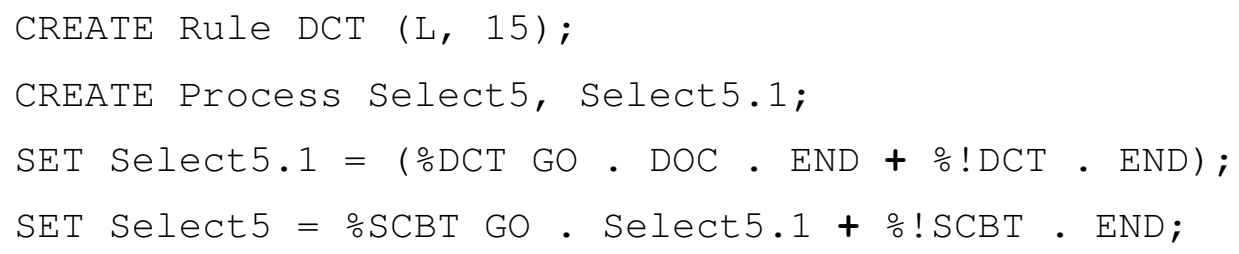

Após a execução da regra SCBT no processo Select5, se algum clone for selecionado, a ação GO libera a execução do processo Select5.1. Caso contrário, a ação END finalizará o 
processo. O processo Select5.1 executa a regra DCT (DistanceCloneTarget), com a definição que os clones obrigatoriamente iniciarão à distância superior a 15 bases do início do alvo.

Caso o processo Select5 seja aplicado na situação ilustrada pela Figura 9, o seguinte clone seria selecionado como ótimo:

- Clone: $\mathbf{F} \rightarrow$ ORF 5 .

\section{- Regra CT (CoverageTarget)}

- CoverageTarget - os clones que selecionam os alvos têm que possuir uma cobertura maior ou igual ou, menor ou igual (Large or Equal "L" ou Less or Equal "l"), a um determinado número de nucleotídeos de seus alvos;

- NumberBases - valor máximo ou mínimo de nucleotídeos que obrigatoriamente representarão o alvo definido.

Exemplo do processo de seleção de clones mapeados em álgebra de processos:

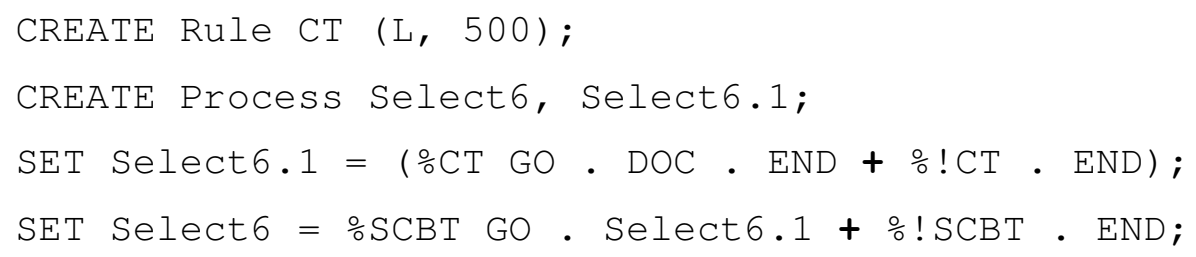

Após a execução da regra SCBT no processo Select6, se algum clone for selecionado, a ação GO libera a execução de Select6.1, caso contrário, a ação END finalizará o processo. O processo Select6.1 executa a regra CT (CoverageTarget), no qual especifica que os clones obrigatoriamente terão cobertura superior a 500 bases do alvo.

Caso o processo Select6 seja aplicado na situação ilustrada pela Figura 10, os seguintes clones seriam selecionados como ótimos:

- Clone: $\mathbf{B} \quad \rightarrow$ ORF 11;

- Clone: D e E $\rightarrow$ ORF 12 .

A Figura 10 ilustra uma situação, na qual aparece uma região promotora e 2 ORFs na seqüência do genoma. 


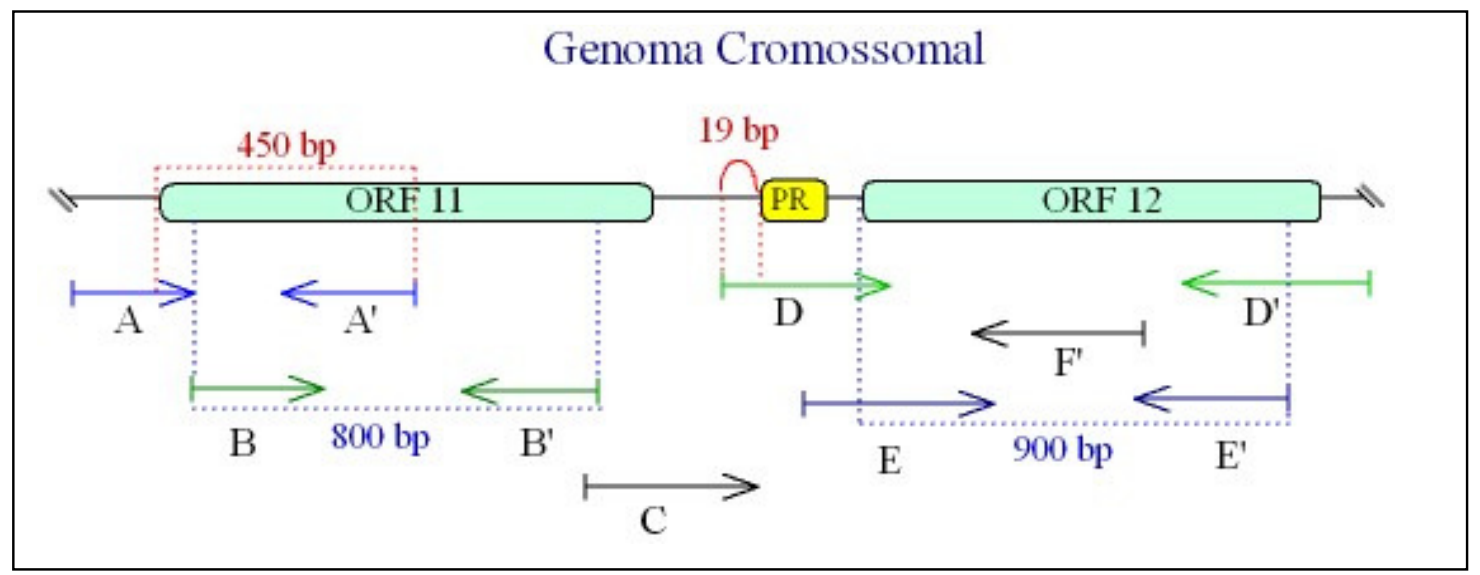

Figura 10 - Representa um fragmento de um genoma com 2 ORFs, na região promotora da "ORF 12" e 6 clones identificados pelas letras $A$ a $F$. O clone $A$ cobre a "ORF 11 " em 450 bases, enquanto que o clone $B$ cobre a mesma ORF com 800 bases. O clone $D$ representa a "ORF 12" por completo e inicia a 19 bases antes de sua região promotora, enquanto que o clone $E$ representa a "ORF 12", cobrindo 900 bases da mesma.

\section{- Regra PR (PromoterRegion)}

- DistancePromotorRegion - distância que o clone tem que iniciar antes de uma região promotora (região de início da transcrição dos genes).

Exemplo do processo de seleção de clones mapeados em álgebra de processos:

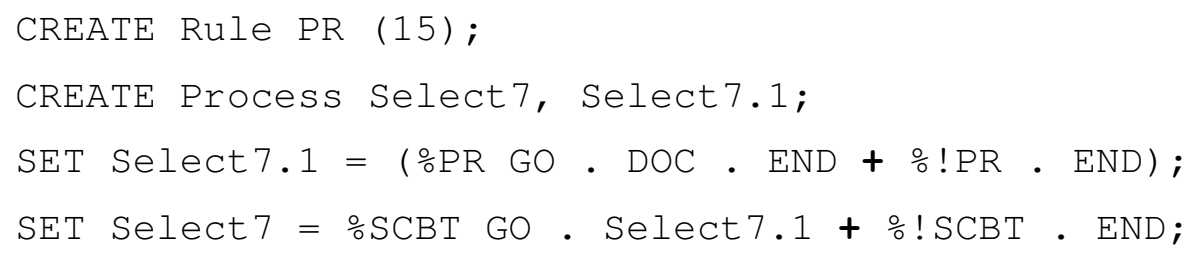

Após a execução da regra SCBT no processo Select7, se algum clone for selecionado, a ação GO libera a execução do processo Select7.1, caso contrário, a ação END finalizará o processo. O processo Select7.1 executa a regra PR (PromoterRegion), no qual especifica que os clones obrigatoriamente têm que possuir uma região promotora e iniciar à distância superior a 15 bases do mesmo.

Caso o processo Select7 seja aplicada na situação ilustrada pela Figura 10, o seguinte clone seria selecionado como ótimo: 
- Clone: D $\rightarrow$ ORF 12.

Durante a elaboração dos processos, o usuário não precisa entender sobre álgebra de processos, NPDL e definição das regras para criar, definir e encadear as atividades que compõem o processo de seleção de clones. Essa questão foi resolvida pelo desenvolvimento de uma interface web amigável, que proporciona a interação entre a ferramenta e o usuário final. Por meio de um browser (programa para navegador na internet), o usuário é capaz de fazer a combinação necessária apenas clicando e selecionado os valores desejados. Finalizada a elaboração do processo, o sistema automaticamente gera a expressão algébrica em NPDL.

\subsection{Modelagem do banco de dados do OCI 2}

O banco de dados da ferramenta $O C I 2$ foi modelado para atender diferentes tipos de projetos, sendo eles: genoma completo, genomas parciais e projetos metagenômicos. As figuras 11 e 12 apresentam os modelos conceitual/lógico e físico do banco de dados do OCI 2. 


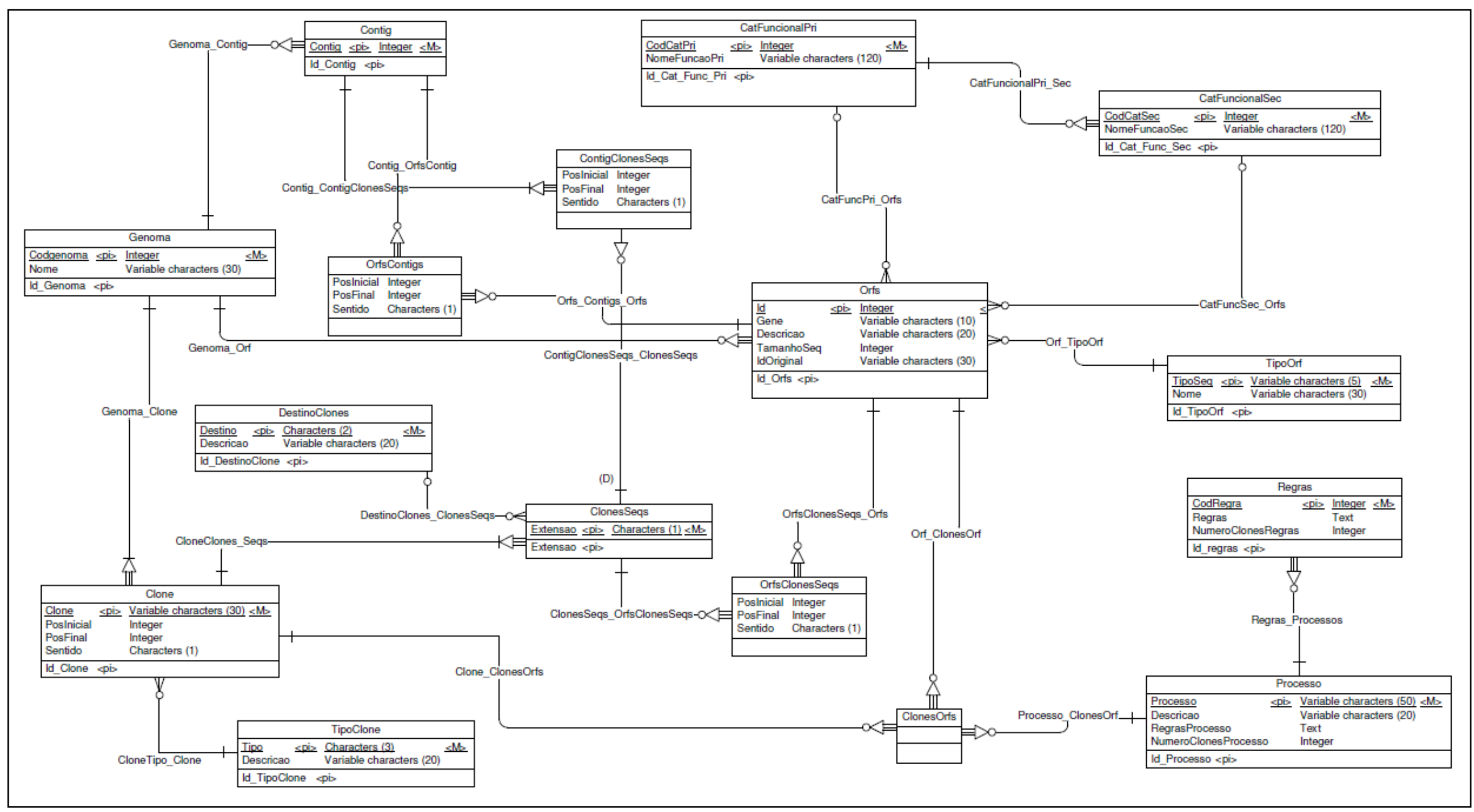

Figura 11 - Modelo conceitual/lógico do banco de dados da ferramenta $O C I 2$ para genomas completos, parciais e metagenômicos 


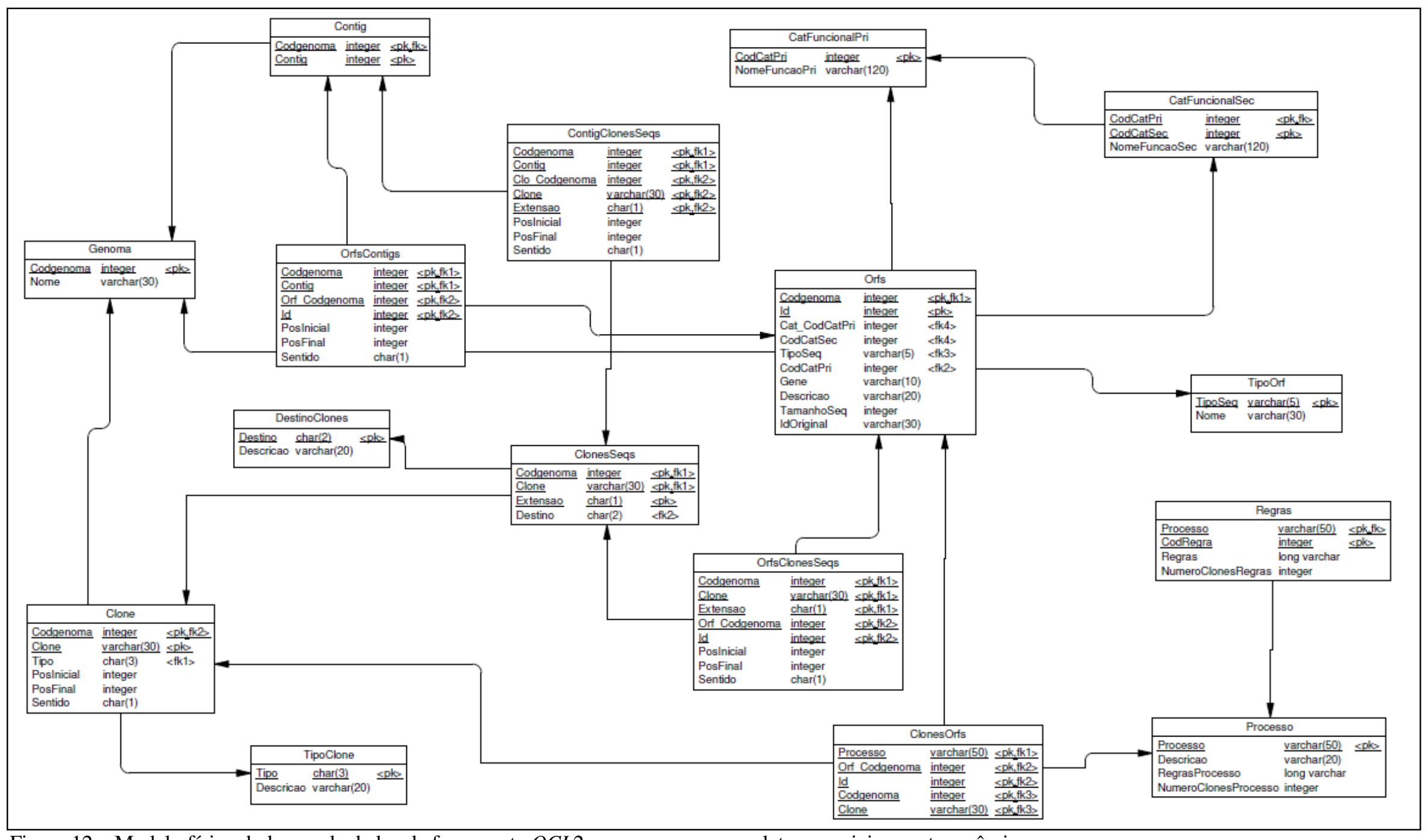

Figura 12 - Modelo físico do banco de dados da ferramenta $O C I 2$ para genomas completos, parciais e metagenômicos 


\subsection{Interface do $O C I 2$}

A ferramenta $O C I 2$ foi desenvolvida para interagir com o usuário final por meio de uma interface web. Desse modo, o pesquisador elabora suas regras de seleção de clones sem a necessidade de saber sobre NPDL e álgebra de processos.

O OCI 2 é baseado no conceito de álgebra de processos que, formalmente, descreve o comportamento do sistema. As expressões algébricas são criadas em NPDL que são interpretadas por meio da NavigationPlanTool (Braghetto et al., 2007). A ferramenta foi desenvolvida em linguagem Perl (http://www.perl.org) e armazena seus dados no banco PostgreSQL (http://www.postgresql.org). A Figura 13 apresenta a interface da versão da ferramenta para projetos de seleção de clones em genomas completos e metagenômicos. Por meio dessa interface, o usuário seleciona as regras que fazem parte do processo de seleção, define seus valores e cria a expressão algébrica.

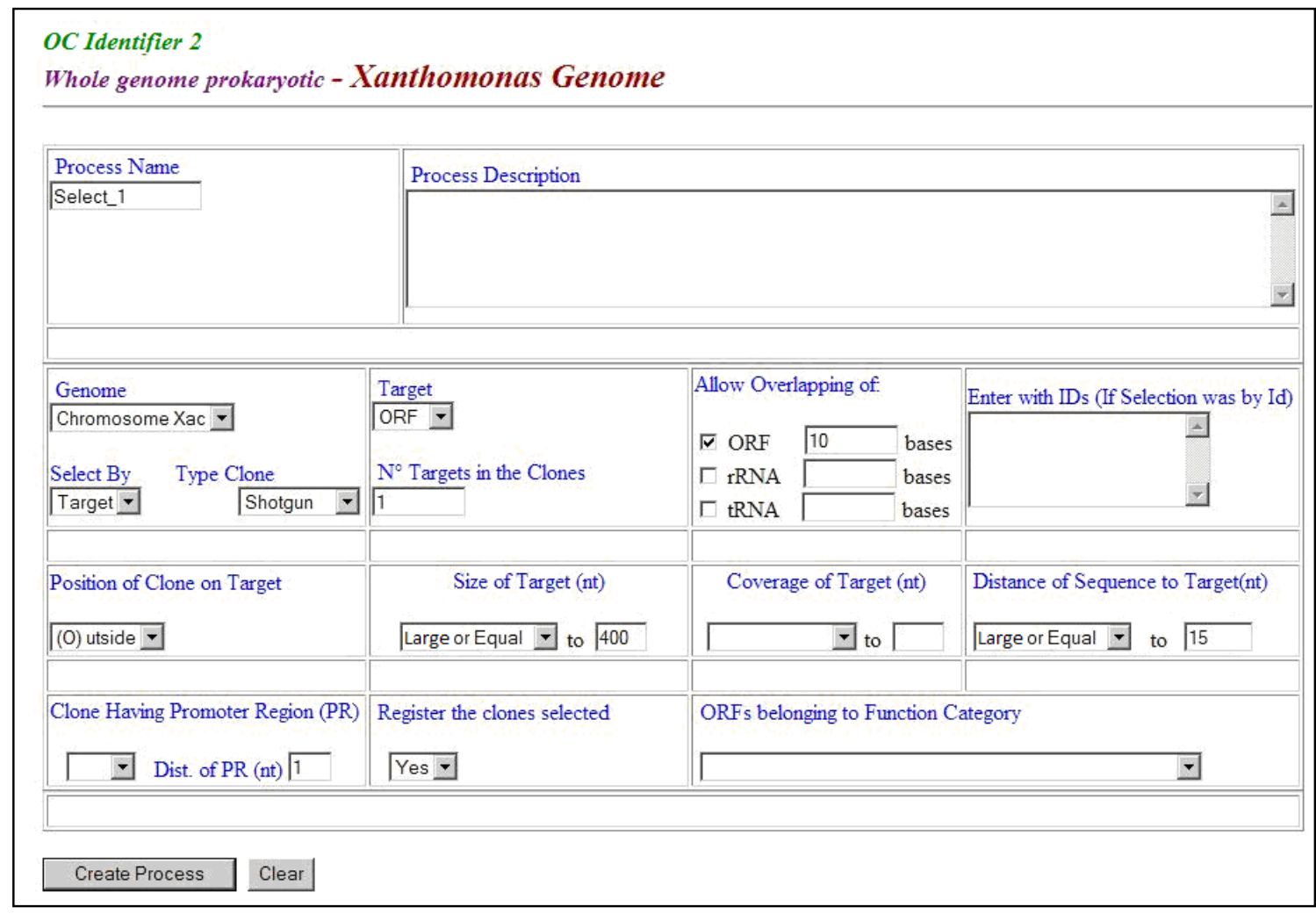

Figura 13 - Interface da ferramenta para projeto de genoma completo de procarioto. Nessa interface, o usuário seleciona quais as atividades que farão parte da regra e define seus valores. Definida as regras, a ferramenta gera a expressão algébrica que representa fielmente o processo de seleção

A interface foi elaborada contendo as regras de seleção de clones ótimos em genomas completos e parciais definidas durante o projeto de seleção de clones no genoma parcial do Bradyrizobium elkanii semia 587 (http://lbmp.fcav.unesp.br/be587), e ao genoma completo da 
Xanthomonas axonopodis pv. citri (Silva et al., 2002). No exemplo de elaboração da regra e seleção de clones na Figura 13, foi usado o genoma completo e anotado da bactéria $X$. axonopodis para ilustrar a criação do processo de seleção denominado Select_l. Nessa seleção, os clones para serem considerados ótimos devem atender as seguintes condições:

- clones do tipo shotgun do genoma cromossomal que contenham 1 ORF de tamanho superior a 400 bases;

- o clone poderá conter sequiência de outra ORF com, no máximo, 10 nucleotídeos, mas nenhuma seqüência de rRNA e tRNA;

- clones localizados externos à ORF e iniciar à distância superior ou igual a 15 bases da mesma.

O nome do processo é definido pelo usuário e usado pela linguagem NPDL para gerar a expressão algébrica. Sendo assim, o processo denominado Select_1, com todas as regras e ações, é mapeado para a seguinte expressão algébrica:

SET Select_1 $=($ oSCBT $(\mathrm{CrO} ; \mathrm{ORF} ; 1 ; 10 ; \mathrm{Sho} ; \mathrm{L}, 400 ; \mathrm{Null})$

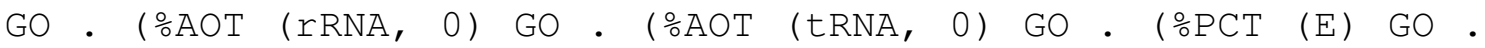
$\left(\% \mathrm{DCT}(\mathrm{L}, 15) \mathrm{GO}\right.$. DOW. END + $\left.\frac{\circ}{\mathrm{D}} \mathrm{DCT}(\mathrm{L}, 15) \mathrm{END}\right)+\frac{\circ}{\circ} \mathrm{PCT}(\mathrm{E})$ $\left.\left.\mathrm{END})+\frac{\circ}{\mathrm{a}} \mathrm{AOT}(\mathrm{tRNA}, 0) \mathrm{END}\right)+\frac{\circ}{\circ} \mathrm{AOT}(\mathrm{RRNA}, 0) \mathrm{END}\right)+\frac{\circ}{\circ} \mathrm{SCBT}$ (Cro; ORF; 1; 10; Sho; L,400; Null) END);

Depois de criado o processo, o mesmo estará disponível para ser executado em uma página que contém os recursos necessários para a execução, cancelamento, edição e exclusão dos processos, como mostra a Figura 14.

\begin{tabular}{|c|c|c|c|c|}
\hline \multicolumn{5}{|c|}{$\begin{array}{l}\text { OC Identifier } 2 \\
\text { Whole genome prokaryotic - Xanthomonas Genome }\end{array}$} \\
\hline Process & Process description & Selected Clones & Edit or Delete & Execute \\
\hline Select_1 & Process Select_1 to Test & & Edit or Delete & Execute \\
\hline \multicolumn{5}{|c|}{ Update Page } \\
\hline \multicolumn{5}{|c|}{ Back } \\
\hline
\end{tabular}

Figura 14 - Página responsável pela execução, cancelamento, edição e exclusão das regras elaboradas

Após a execução dos processos, os nomes dos clones selecionados estarão disponíveis para download, assim como o resultado do número de clones selecionados por cada regra. As páginas que elaboram e executam os processos, como também as informações detalhadas do processamento podem ser visualizadas no seguinte endereço web http://tecnol86.fcav.unesp.br/Xantho 
Como apresentado anteriormente, além de genomas completos, também é possível a seleção de clones em genomas parciais. Nos genomas parciais, as regiões ainda não seqüenciadas são chamadas gaps e as presenças nas sequiências modificam a forma como os clones serão selecionados, sendo essa a principal diferença entre a versão da ferramenta de seleção de clones em genomas completos e parciais. Para que as seleções de clones ocorram em genomas parciais, um novo atributo foi adicionado às regras iniciais (SCBT e SCBI). Esse novo atributo indica ao processo de seleção, qual a localização exata dos clones que serão analisados.

Os clones que compõem os genomas parciais se encontram em uma das seguintes situações:

- Same Contig: (CC_S) - clones localizados no mesmo contig;

- Different Contigs: (CC_D) - clones localizados em contigs diferentes;

- Singlet and Contig: (SC) - uma das sequiências do clone localizada em contig e a outra como singlet;

- Singlets: (SS) - clones fora dos contigs.

A Figura 15 apresenta a interface da versão da ferramenta $O C I 2$ que elabora a seleção de clones em genomas parciais. Nessa interface, a seta vermelha indica o novo campo adicionado 'Clones Localization', indicado pela seta vermelha.

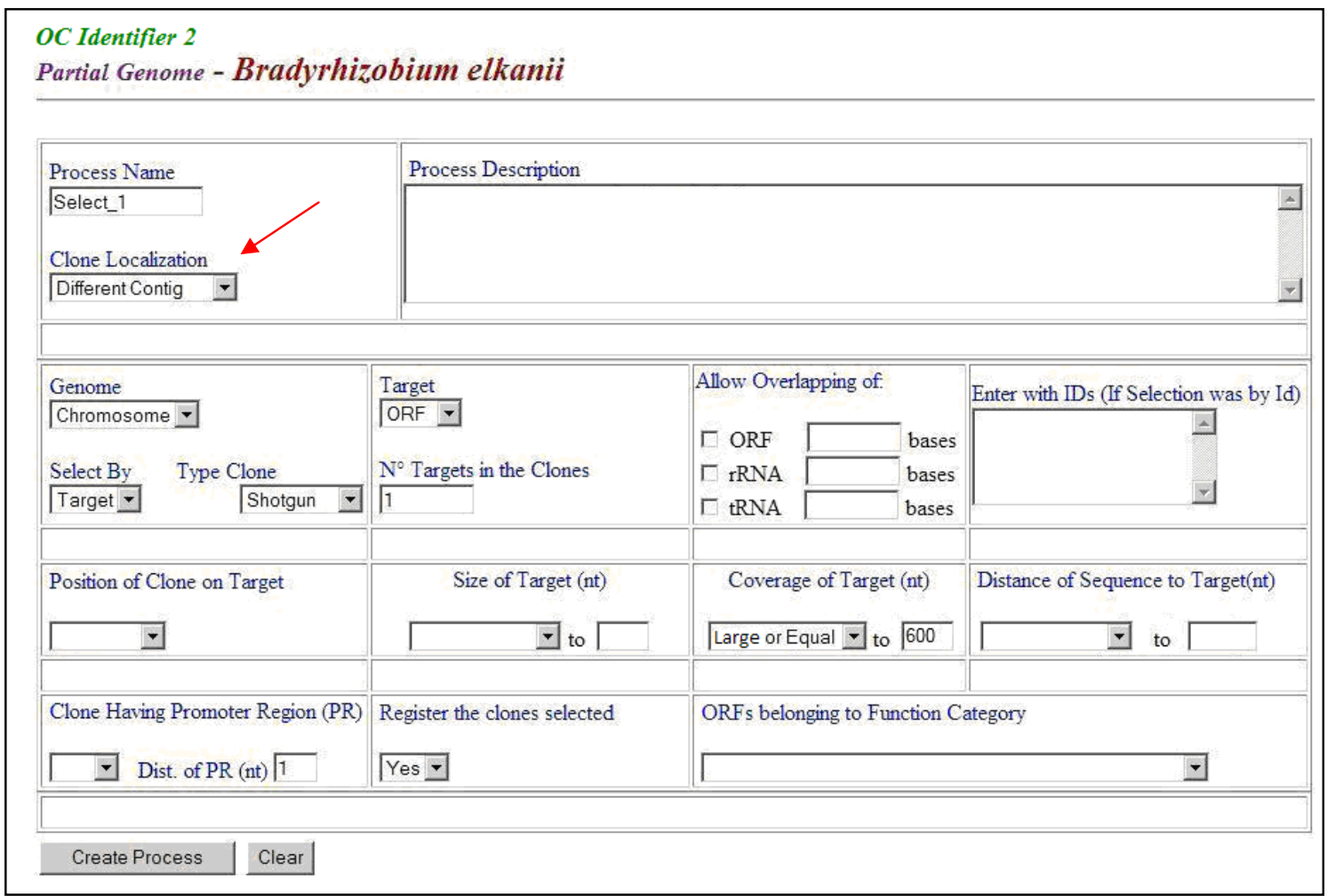

Figura 15 - Interface da ferramenta no projeto de genoma parcial. Essa interface apresenta a adição da nova informação 'Clone Localization' ao processo de seleção de clones 
A Figura 15 mostra o exemplo de seleção no genoma parcial da bactéria Bradyrhizobium elkanii Semia 587 e apresenta os parâmetros usados no processo de seleção dos clones chamado de Select_1. Nesse processo, os clones selecionados terão suas seqüências (forward e reverse) localizadas em diferentes contigs, e separados por um gap. Adicionalmente, os clones devem satisfazer as seguintes condições de seleção:

- clones do tipo shotgun do genoma cromossomal que contenham 1 ORF e que representem no mínimo, 600 bases da mesma.

Dessa forma, quando o processo Select_l é mapeado para NPDL gera a seguinte expressão algébrica:

SET Select_1 = (\% SCBT (CC_D; CrO; ORF; 1; 0; Sho; Null; Null) GO • (\%AOT (rRNA, 0) GO • (\%AOT (tRNA, 0$)$ GO • (\%CT ( L, $600) \mathrm{GO}$. DOW. END + $\left.\frac{\circ}{\mathrm{C} C \mathrm{CT}}(\mathrm{L}, 600) \mathrm{END}\right)+\%$ ! AOT ( tRNA, 0$)$ END) + ! AOT ( $\mathrm{RNA}, 0)$ END) + $\frac{\circ}{\circ}$ !SCBT (CC_D; CrO; ORF; 1; 0 ; Sho; Null; Null) END);

Depois de criado e executado o processo, é possível visualizar os clones selecionados, assim como o número de clones identificados para cada regra processada, como mostra a Figura 16.

OC Identifier 2

Partial genome prokaryotic - Genome Bradyrhizobium

\begin{tabular}{|l|l|}
\hline \multicolumn{1}{|c|}{ Rules Applied } & Clones Selected \\
\hline Selection Clones by Target & 144 \\
\hline Analysis of Overlap Target (rRNA) & 144 \\
\hline Analysis of Overlap Target (tRNA) & 144 \\
\hline Coverage of Target $>=600$ & 141 \\
\hline Finalization Process & 141 \\
\hline
\end{tabular}

\begin{tabular}{|l|l|l|}
\hline \multicolumn{1}{|c|}{ Clones Selected } & \multicolumn{1}{c|}{ IDs } & \multicolumn{1}{c|}{ Original IDs } \\
\hline BEJE0101H09 & 717 & 3129 \\
\hline BEJE0102C04 & 940 & 1016 \\
\hline BEJE0108H01 & 59 & 1665 \\
\hline
\end{tabular}

Figura 16 - Visualização do número de clones selecionados por cada regra e os clones selecionados após a finalização do processo 
Além de visualizar o resultado de cada processo, é possível efetuar o download da lista dos clones selecionados ou mesmo cancelar o processamento para eventual alteração em suas regras, como mostra a Figura 17.

\begin{tabular}{|c|c|c|c|c|}
\hline \multicolumn{5}{|c|}{$\begin{array}{l}\text { OC Identifier } 2 \\
\text { Partial genome prokaryotic - Genome Bradyrhizobium }\end{array}$} \\
\hline Process & Process description & Clones Selected & \multirow[t]{2}{*}{ Edit or Delete } & Execute \\
\hline Select_1 & Test of Selection & 141 Download & & Cancel \\
\hline \multicolumn{5}{|c|}{ Update Page } \\
\hline \multicolumn{5}{|c|}{ Back } \\
\hline
\end{tabular}

Figura 17 - Após a execução dos processos é possível visualizar, cancelar ou fazer download dos resultados

As páginas que elaboram e executam os processos, como também o resultado detalhado do processamento podem ser visualizados na seguinte página web http://tecnol86.fcav.unesp.br/BE

\subsection{Cadastro dos dados no sistema}

Para realizar o processo de seleção é necessário que os dados sobre clones e ORFs estejam cadastrados. Os dados sobre seqüências de RNAr, RNAt, região ITS, região promotora e categorias funcionais dos genes não são obrigatórios para o processo de seleção, porém, a sua presença permite maior poder de seleção dos mesmos.

O cadastro é realizado por meio de um arquivo de texto que contém os dados delimitados por tabulações, denominado TSV (do inglês Tab Separated Values). O caracter tab é utilizado para separar os textos em cada campo e informa suas posições finais. Com o propósito de facilitar a visualização dos exemplos apresentados neste trabalho, os delimitadores tabs são substituídos pelo símbolo $(\rightarrow)$, o que permite a distinção visual entre dados genômicos e os delimitadores.

A seguir, são apresentadas as formatações dos arquivos de cadastro para análises em genomas completos e parciais.

\subsubsection{Formatação dos arquivos em genomas completos}

Para o cadastro das ORFs, RNAr e RNAt de genomas completos, adotou-se o formato PTT (do inglês Protein Table) do NCBI (do inglês National Center for Biotechnology 
Information - http://www.ncbi.nlm.nih.gov). O formato PTT do NCBI consiste de campos com informações para cada gene e inclui os dados de localização gênica, sentido de leitura, identificador, categoria funcional baseada no COG (do inglês Clusters of Orthologous Groups) (http://www.ncbi.nlm.nih.gov/COG) e função, como mostra a Figura 18.1.

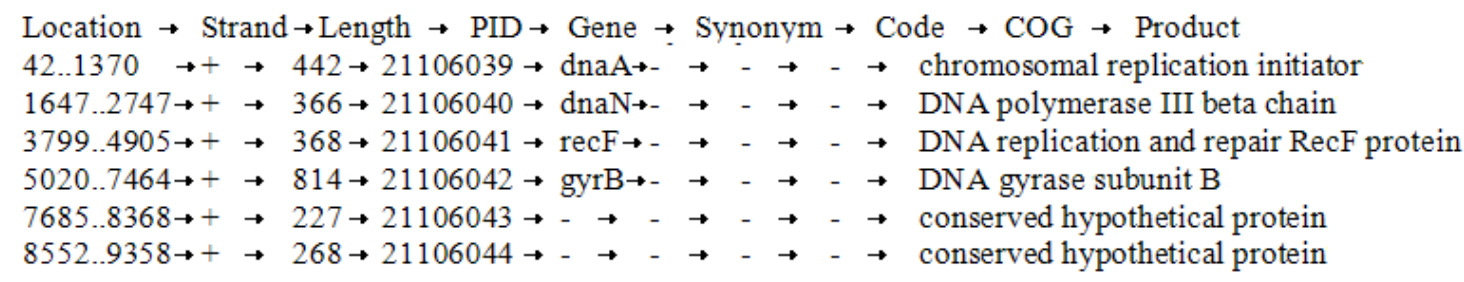

Figura 18.1 - Exemplo do arquivo de cadastro das ORFs no formato protein table. Cada campo no arquivo é separado pelo delimitador $t a b$

Os arquivos que contêm o formato protein table geralmente finalizam com a extensão "ptt” para os genes, "rnt" para as seqüências de RNAr e RNAt, e estão disponíveis para todos os genomas bacterianos completos em ftp://ftp.ncbi.nih.gov/genomes/Bacteria (Stothard e Wishart, 2005).

Para o cadastro dos clones é necessário que o arquivo seja composto pelos seguintes campos:

- Clone - nome do clone;

- Strand - sentido do clone na sequiência do genoma. Senso (+), Anti-senso (-);

- Start_Position: Posição inicial do clone na sequiência do genoma;

- End_Position - Posição final do clone na sequiência do genoma.

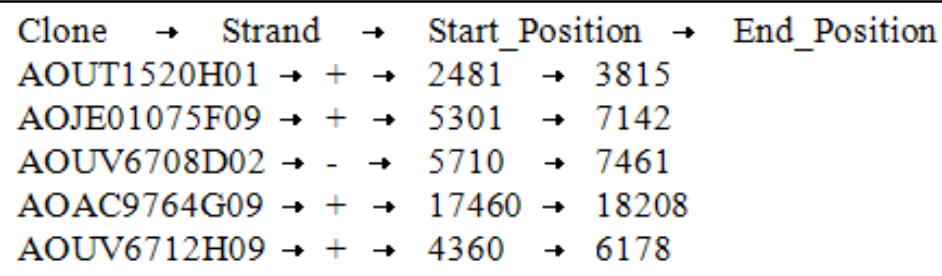

Figura 18.2 - Exemplo do arquivo de cadastro dos clones que compõem o genoma

As informações sobre o tipo de clone e qual genoma os clones pertencem são definidas na página de upload do sistema, desse modo não é necessário adicionar no arquivo de cadastro.

A adição dos dados secundários, tais como, região promotora, região ITS e atribuir categorias funcionais aos genes seguem o mesmo processo de inclusão dos dados primários. Esse arquivo deve possuir o formato mostrado a seguir.

- Arquivo com regiões promotoras ou ITS: 
- Id_Project - identificador da região promotora no projeto;

- Strand - sentido de leitura da região promotora, senso (+), Anti-senso (-);

- Start_Position - posição inicial da região promotora na seqüência do genoma;

- End_Position - posição final da região promotora na sequiência do genoma.

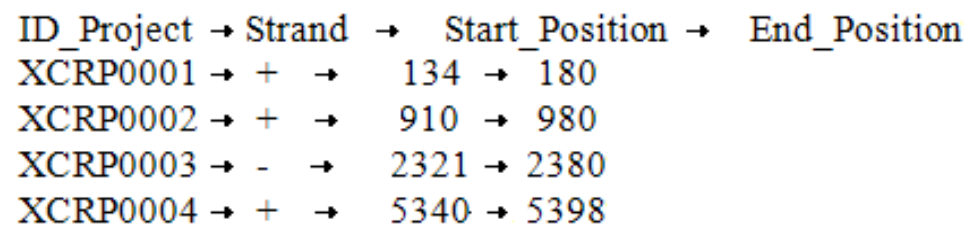

Figura 18.3 - Exemplo do arquivo de cadastro das regiões promotoras ou ITS

As informações sobre o tipo da ORF, genoma e localização no genoma (clones ou contigs) que as seqüências pertencem são definidas na página de upload do sistema, desse modo não é necessário adicionar no arquivo de cadastro. O campo ID_Project contém o código de identificação da seqüência no projeto original, isto é, seu identificador no projeto de onde as sequiências foram importadas.

- Arquivo de categorias funcionais:

- First_Cat_Func - categoria funcional primária;

- Sec_Cat_Func - categoria funcional secundária;

- Function - descrição da categoria funcional.

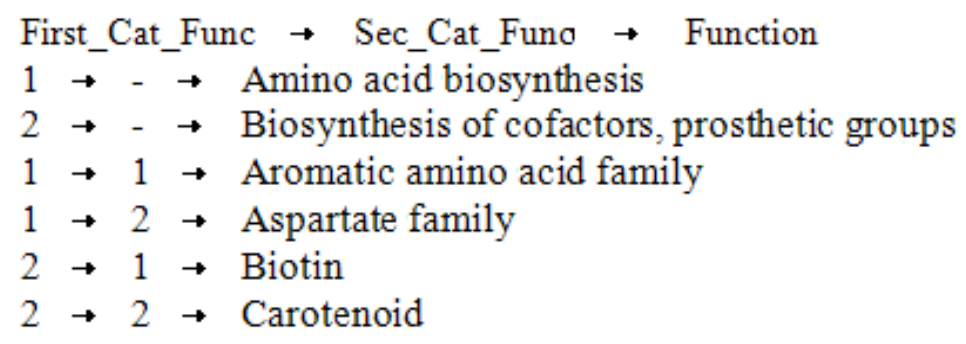

Figura 18.4 - Exemplo do arquivo de cadastro das categorias funcionais

- Arquivo de atribuição às categorias funcionais aos genes:

- Id_Project - identificador da ORF no projeto;

- First_Cat_Func - código da categoria funcional primária;

- Sec_Cat_Func - código da categoria funcional secundária. 


$$
\begin{aligned}
& \text { ID_Project } \rightarrow \text { First_Cat_Func } \rightarrow \text { Sec_Cat_Func } \\
& 21106039 \rightarrow 1 \rightarrow 2 \\
& 21106040 \rightarrow 1 \rightarrow 1 \\
& 21106041 \rightarrow 2 \rightarrow 1 \\
& 21106042 \rightarrow 13 \rightarrow- \\
& 21106043 \rightarrow 15 \rightarrow-1
\end{aligned}
$$

Figura 18.5 - Exemplo de arquivo de cadastro das categorias funcionais para cada ORF no genoma

\subsubsection{Formatação dos arquivos em genomas parciais}

Em genomas parciais, as informações dos clones e ORFs aparecem de modo diferente dos projetos de genomas completos. Dessa forma, a formatação dos arquivos de cadastros também é diferente. Portanto, a seguir serão apresentados os arquivos com seus respectivos formatos para o cadastrado no banco do sistema.

- Arquivo com os dados de ORF, RNAt ou RNAr:

- ID Project - identificador da seqüência da ORF, RNAt ou RNAr no projeto original;

- Gene - nome do gene;

- Product - descrição do gene.

ID Project $\rightarrow$ Gene $\rightarrow$ Product
$1 \rightarrow-\rightarrow$ anaerbic coproporphyrinogen III oxidase
$2 \rightarrow-\rightarrow$ 3,4-dihydroxy-2-butanone-4-phoshate-synthase
$3 \rightarrow-\rightarrow$ biotin carboxylase subunit of acetyl-CoA
$4 \rightarrow-\rightarrow$ nicotinate phosphoribosyltransferase
$5 \rightarrow-\rightarrow$ aspartate 1-decarboxylase precursor

Figura 19.1 - Exemplo do arquivo de cadastro das ORFs presentes no genoma

- Arquivo que indica os dados das ORFs, RNAt ou RNAr que estão localizados nas sequiências dos contigs:

- ID_Project - identificador da seqüência da ORF, RNAt ou RNAr no projeto original;

- Strand - sentido da transcrição;

- Contig - número do contig em que a sequiência está localizada;

- Start_Position - posição inicial da seqüência no contig;

- End_Position - posição final da seqüência no contig 


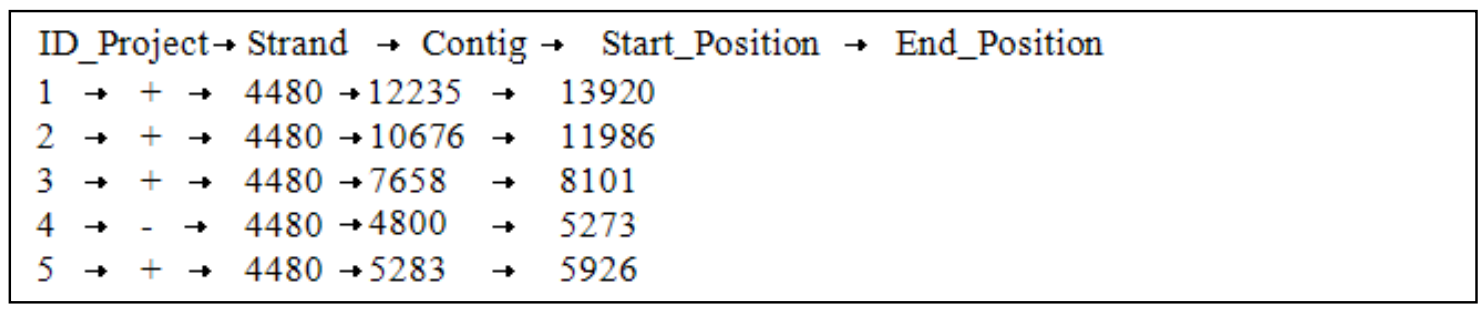

Figura 19.2 - Exemplo do arquivo de cadastro das ORFs nas seqüências dos contigs

- Arquivo que indica os dados das ORFs, RNAt ou RNAr que estão localizadas nas seqüências dos clones:

- ID_Project - identificador da seqüência da ORF, RNAt ou RNAr atribuída ao projeto;

- Strand - sentido da transcrição;

- Clone - nome do clone em que a seqüência está localizada;

- Extensao - oligonucleotídeo universal usado na amplificação da seqüência, sendo a letra "b" para o oligonucleotídeo forward e "g" para reverse.

- Start_Position - posição inicial;

- End_Position - posição final.

ID_Project $\rightarrow$ Strand $\rightarrow$ Clone $\rightarrow$ Extensao $\rightarrow$ Start_Position $\rightarrow$ End_Position
$43 \rightarrow-\rightarrow$ BEJE0135E08 $\rightarrow$ g $\rightarrow 136 \rightarrow 631$
$129 \rightarrow-\rightarrow$ BEJE0152F03 $\rightarrow$ g $\rightarrow 63 \rightarrow 734$
$302 \rightarrow+\rightarrow$ BEJE0184A02 $\rightarrow$ b $\rightarrow 81 \rightarrow 1350$
$308 \rightarrow-\rightarrow$ BEJE0125G04 $\rightarrow$ b $\rightarrow 76 \rightarrow 1838$
$312 \rightarrow+\rightarrow$ BEJE1045D07 $\rightarrow$ b $\rightarrow 2 \rightarrow 810$

Figura 19.3 - Exemplo do arquivo de cadastro das ORFs nas seqüências dos clones

Além das ORFs, são cadastrados os clones que compõem o genoma. No caso de genomas parciais, as seqüências dos clones amplificados pelos oligonucleotídeos universais, podem estar localizadas em diferentes regiões do genoma e separadas por gaps. Nesse caso, o arquivo de cadastro dos clones contém a localização específica das seqüências.

Para isso, o arquivo de cadastrado dos clones contém os seguintes campos:

- Clone - nome do clone;

- Extensao - oligonucleotídeo usado na amplificação do clone;

- Contig - o numero do contig em que o clone se localiza;

- Strand - sentido do clone no contig, senso ou anti-senso;

- Start_Position - posição inicial do clone no contig;

- End_Position - posição final do clone no contig. 


Clone $\rightarrow$ Extensao $\rightarrow$ Contig $\rightarrow$ Strand $\rightarrow$ Start_Position $\rightarrow$ End_Position
BEJE0135A01 $\rightarrow$ b $\rightarrow 1 \rightarrow+\rightarrow 10$
BEJE0135A01 $\rightarrow$ g $\rightarrow 1 \rightarrow-\rightarrow 1160 \rightarrow 1670$
BEJE0135E08 $\rightarrow$ b $\rightarrow 1 \rightarrow+\rightarrow 30 \rightarrow 600$
BEJE0135E08 $\rightarrow$ g $\rightarrow 1 \rightarrow-\rightarrow-1350 \rightarrow 1970$
BEJE0135E10 $\rightarrow$ b $\rightarrow-\rightarrow-\rightarrow-\rightarrow-$
BEJE0135E10 $\rightarrow$ g $\rightarrow-\rightarrow-\rightarrow-\rightarrow-$

Figura 19.4 - Exemplo do arquivo de cadastro dos clones que compõem o genoma

- Arquivo de cadastro das regiões promotoras e região ITS:

- ID_Project - identificador da região promotora ou ITS recebida pelo projeto;

- Contig - o número do contig em que a região promotora ou ITS se localiza;

- Strand - sentido, senso ou anti-senso da região promotora ou ITS no contig;

- Start_Position - posição inicial do clone no contig;

- End_Position - posição final do clone no contig.

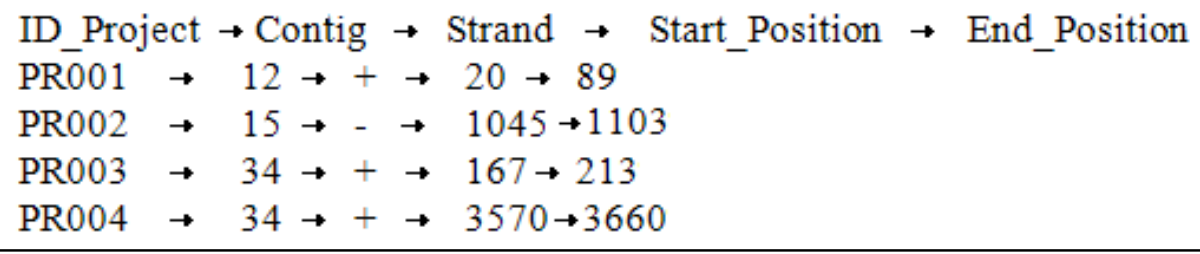

Figura 19.5 - Exemplo do arquivo de cadastro da região promotora ou ITS nas seqüências do genoma

$\mathrm{O}$ arquivo de categorias funcionais e suas atribuições aos genes possuem os mesmos formatos apresentados no projeto de genomas completos. Sendo assim, tais arquivos podem ser vistos nas Figuras 18.4 e 18.5, respectivamente.

\subsubsection{Página de cadastros e listagem dos dados}

A página de cadastro dos dados primários e secundários, assim como os tipos de seqüências genômicas (genoma cromossomal, plasmidial, cosmidial), e os tipos de seqüências (shotgun, cosmídeo) são as mesmas para ambas as versões da ferramenta (genomas completos e parciais). A seguir, a Figura 20 apresenta à página de cadastros dos tipos de sequiências genômicas e a Figura 21 a página com o sistema de upload dos arquivos. 
OC Identifier 2 - Genome sequence

\section{List of Genome Sequences Registered}

Chromosome $\square$

c Insert New

Remove Plasmideo1

Submit

List of Type Sequences Registered

Shotgun $\square$

c Insert New

Remove Cosmideo

Submit

Figura 20 - Página de cadastro dos tipos de seqüências genômicas 


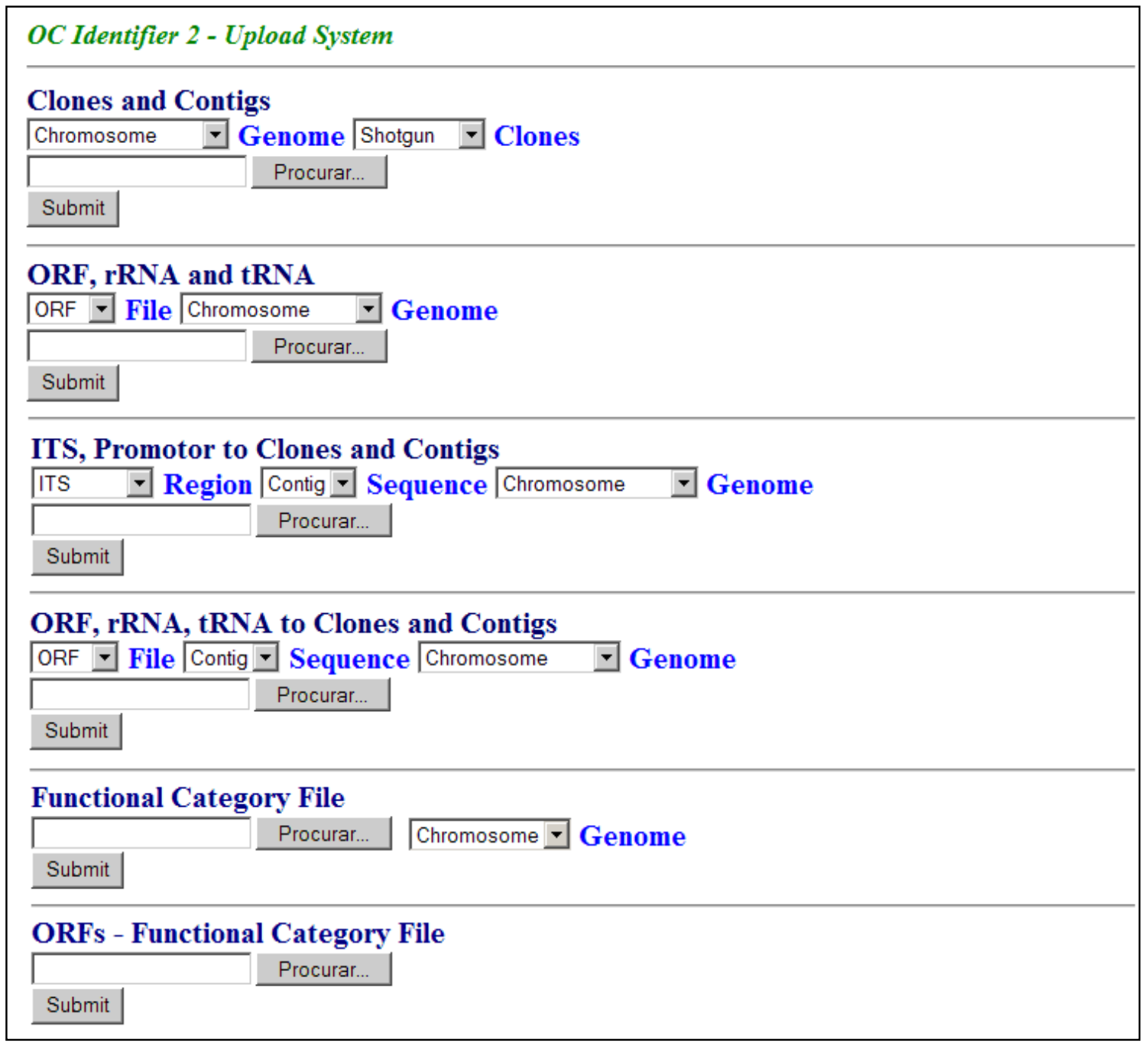

Figura 21 - Página que realiza o upload dos arquivos para cadastramento dos dados primários e secundários ao sistema

Como apoio à consulta, uma relação com todas as seqüências de um projeto pode ser listada, como mostra a Figura 22. 
OC Identifier 2 - List Orfs and Description

Whole genome prokaryotic - Genome Xanthomonas

\begin{tabular}{|l|l|l|}
\hline \multicolumn{1}{|c|}{ IDs } & \multicolumn{1}{|c|}{ IDs Project } & Description \\
\hline 1 & 21106039 & chromosomal replication initiator \\
\hline 2 & 21106040 & DNA polymerase III beta chain \\
\hline 3 & 21106041 & DNA replication and repair RecF protein \\
\hline 4 & 21106042 & DNA gyrase subunit B \\
\hline 5 & 21106043 & conserved hypothetical protein \\
\hline 6 & 21106044 & conserved hypothetical protein \\
\hline 7 & 21106045 & conserved hypothetical protein \\
\hline 8 & 21106047 & TonB protein \\
\hline 9 & 21106048 & biopolymer transport ExbB protein \\
\hline 10 & 21106049 & biopolymer transport ExbD1 protein \\
\hline
\end{tabular}

Figura 22 - Lista das seqüências cadastradas no sistema.

\subsection{Análise de desempenho do OC Identifier x OCI 2}

Com a finalidade de apresentar os tempos de processamentos entre as versões da ferramenta que gerencia as regras pelo código do sistema e abordagem algébrica, foi definida uma regra de seleção e executado com diferentes números de clones cadastrados.

Para tais análises, as principais configurações de hardware e software foram às seguintes:

\section{- Hardware}

- Processador Intel Core 2 Quad $2.33 \mathrm{GHz}$;

- 4 GB de Memória RAM DDR2 800 MHz;

- HD SATA 500 GB 7.200 RPM.

- Software

- Sistema Operacional Linux Ubuntu 8.04 - 32 bits;

- Linguagem Perl 5.8.8;

- Banco MySQL 5.0 (usado no OC Identifier);

- Banco PostgreSQL 8.2.7 (usado no OCI 2). 


\subsubsection{Desempenho entre as versões OCI 1 e OCI 2}

O principal objetivo da análise do tempo de processamento entre as duas versões da ferramenta é verificar se a mudança na forma de gerenciamento das regras compromete significativamente o tempo total das análises. Para isso, foi elaborada a mesma regra de seleção para ambas as versões e processadas com diferentes números de clones para cada análise.

O processo para a seleção dos clones atende as seguintes condições:

- clones contendo $1 \mathrm{ORF}$;

- localizados na mesma seqüência dos contig;

O resultado do tempo de processamento pode ser visto na Figura 23.

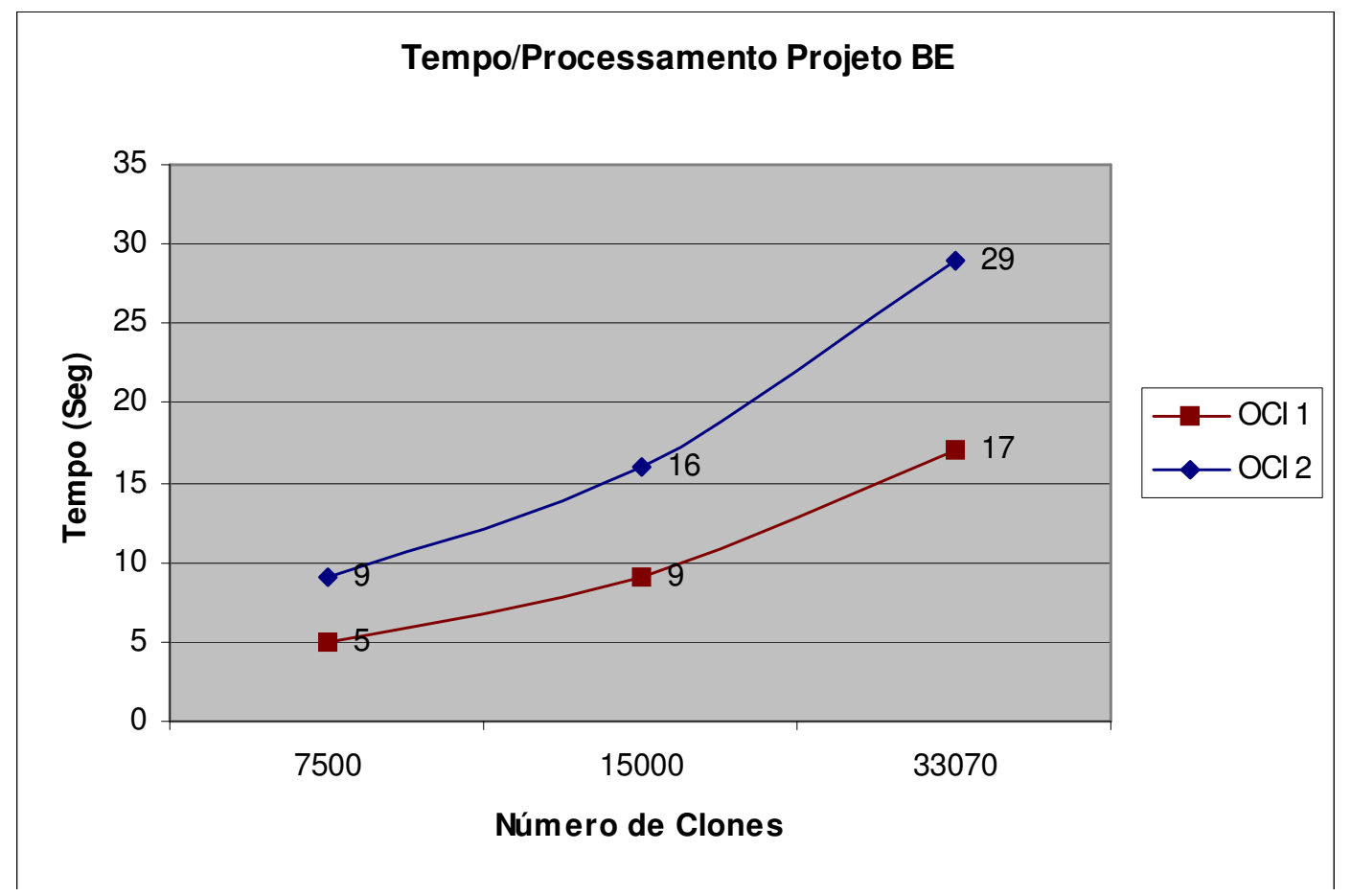

Figura 23 - Tempo de processamento em relação ao número de clones presentes na consulta

As análises foram iniciadas com 7.500 clones e atingiu seu valor máximo de 33.070 clones, sendo este o número total de clones seqüenciado no projeto do genoma do B. elkanii. Os mesmos valores foram usados nas duas versões do softwsare e apresentaram resultados diferentes no tempo de processamento entre eles. Com 7.500 clones, enquanto que a versão algébrica (OCI 2) precisou de 9 segundos para finalizar as análises, a versão da regra em código de programação do $O C$ Identifier $(O C I$ 1) e levou 5 segundos. Ao dobrar a quantidade 
de clones no banco, o tempo de processamento do OCI 2 passou de 9 para 16 segundos, enquanto que o $O C I 1$ passou de 5 para 9 segundos.

Para finalizar as análises de tempos, o processamento foi realizado com todos os clones presentes na montagem do genoma parcial, sendo de 33.070. Nessa última análise, o OCI 2 concluiu o processamento com 29 segundos, contra 17 segundos do OCI 1.

Com os tempos obtidos para cada conjunto de clones nas duas versões, fica claro que o tempo de processamento para a versão algébrica ficou em torno de $55 \%$ mais lento que a versão das regras mapeadas no código fonte do aplicativo. Mesmo a versão algébrica sendo mais lenta que a versão tradicional, o tempo total das análises não compromete o projeto, uma vez que a diferença entre as análises de todos os clones do genoma foi de poucos segundos. Quando a analisar é flexibilidade do sistema, a versão algébrica possibilita que as regras sejam completamente reformuladas e o novo código gerado automaticamente apenas alterando a expressão algébrica. Nesse sentido, em questão de segundos é possível alterar o comportamento do sistema para se adaptar as novas regras de seleção, enquanto que a alteração das regras por meio do código fonte há a necessidade de reprogramar o código para realizar tais alterações.

O uso de uma abordagem algébrica no controle do fluxo do sistema demonstrou ser viável quanto ao tempo total de execução das regras, uma vez que a pequena diferença de tempo entre as versões não comprometeu as análises dos dados.

\subsubsection{Desempenho do OCI 2}

No teste de desempenho realizado na versão algébrica da ferramenta, o processo de seleção foi definido para selecionar clones com 1 ORF no genoma cromossomal do genoma da $X$. citri e processado em diferentes conjuntos de clones, sendo eles, 1.000, 10.000, 100.000 e 1.000.000.

O resultado da análise do tempo de processamento pode ser visto na Figura 24. 


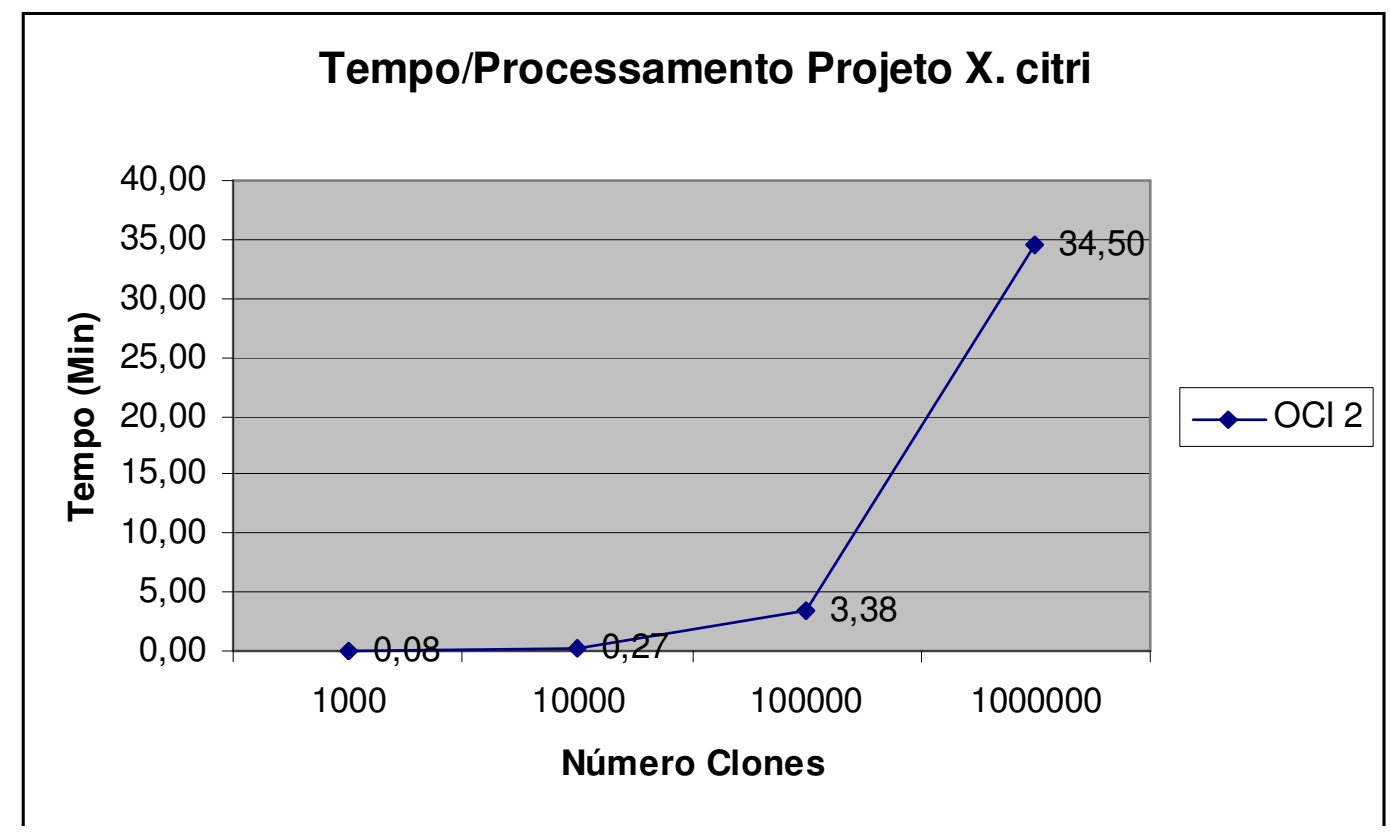

Figura 24 - Evolução no tempo de processamento de seleção dos clones no genoma completo de X. citri

As análises foram iniciadas com 1.000 clones e atingiram o valor máximo de 1.000 .000 clones. Com 1.000 clones, foram necessários 0,08 minutos (5 segundos) para finalizar as análises e, com 10.000, o tempo passou de 0,08 para 0,27 minutos (16 segundos). Com 100.000 clones, o tempo de processamento foi de 3,38 minutos (203 segundos), na última análise, o processamento foi realizado com 1.000.000 de clones e o tempo total necessário foi de 34,5 minutos (2.070 segundos). Levando em consideração que um cosmídeo de projetos metagenômicos varia em torno de $30 \mathrm{a} 40 \mathrm{~Kb}$, e o projeto é finalizado com o seqüenciamento de aproximadamente 1.000 clones, o tempo de consulta ao clone ótimo será de poucos segundos. Quando as análises são realizadas em projetos genomas de procariotos, cujo são finalizados com o seqüenciamento entre 50 a 100 mil clones, a busca ao clone ótimo será finalizada em torno de 200 segundos.

Dessa forma, o tempo necessário para as buscas aos clones ótimos não é um fator limitante, pois ela pode ser realiza em um curto período de tempo. O maior desafio ainda continua sendo todo o processo que antecede a busca aos clones, tanto em questão de tempo como complexidade que são exigidas para o processo de seqüenciamento, montagem e anotação do genoma. 


\section{Capítulo 6}

\section{Resultados obtidos e conclusões}

O primeiro resultado do projeto foi o desenvolvimento das regras de seleção de clones ótimos e sua implementação na ferramenta $O C$ identifier tool (Cantão et al., 2007), usando a abordagem de linguagem de programação no controle e gerenciamento dos fluxos dos processos. A ferramenta $O C$ identifier selecionou 2.654 clones contendo genes únicos do genoma seqüenciado, parcialmente, da bactéria Bradyrhizobium elkanii Semia 587 para compor um microarranjo de DNA. Esse microarranjo foi usado por Marcondes et al. (2008) nos estudos de expressão gênica da bactéria em diferentes fases de crescimento e por Pereira (2007) na comparação de genomas por CGH para análises filogenéticas.

Com a necessidade de expandir as análises, a fim de alcançar novos tipos de organismos e projetos, o sistema foi reestruturado e passou a ser controlado por meio de abordagem algébrica. Desse modo, a versão das regras mapeadas em álgebra de processos do $O C$ Identifier foi implementada na ferramenta OCI 2 - Optimal Clone Identifier based on Dynamic Rules and Process Algebra - (Cantão et al., 2009), a qual foi empregada nas análises de dois genomas bacterianos, sendo eles: genoma completo de Xanthomonas axonopodis pv. citri, genoma parcial de B. elkanii e na seleção de clones em projeto metagenômico.

\subsection{Resultados da seleção de clones ótimos com OC Identifier tool}

A seleção de clones ótimos, com o uso do OC Identifier foi aplicada primeiramente no genoma parcial de Bradyrizobium elkanii Semi 587 que continha as seguintes informações:

- 8.008 clones de shotgun seqüenciados;

- 3.8 milhões de nucleotídeos seqüenciados;

- 2.522 contigs gerados pela montagem;

- 3.374 sequiências de singlets;

- 3.207 ORFs, 31 RNAt; 2 RNAr. 
Baseados nos dados produzidos pela montagem, dos 8.008 clones disponíveis para análises, 2.654 foram selecionados pela ferramenta $O C$ Identifier, contendo genes únicos e usados na confecção de um microarranjo de DNA (Cantão et al., 2007). Esse microarranjo foi usado por Marcondes et al. (2008) nas análises dos perfis transcricionais de B. elkanii cultivada in vitro nos meios de cultura RDM (do inglês Rhizobia Defined Medium) e TY (do inglês Triptone-Yeast), durante as fases lag, $\log$ e estacionária de crescimento, e nas análises de transcriptomas dos genes envolvidos no metabolismo de B. elkanii cultivada em laboratório e em simbiose com plantas de soja (Glycine Max), quanto ao caráter de fixação biológica do nitrogênio.

Concomitante as análises transcricionais, o mesmo microarranjo foi usado por Pereira (2007) na comparação de genomas por hibridização entre os genomas Bradiryzobium japonicum, Azorhizobium caulinodans, Mesorhizobium huakuii, Rhizobium leguminosarum biovar trifolii e Sinorhizobium meliloti, para fins de filogenia por CGH.

O emprego das mesmas seqüências produzidas no seqüenciamento parcial do genoma do B. elkanii, possibilitou que três projetos com diferentes finalidades fossem desenvolvidos em um curto espaço de tempo e com menor custo. Isso foi possível, pois, as mesmas sequiências dos clones foram reutilizadas nos três projetos. Sendo assim, evitou o alto custo com a síntese de oligonucleotídeos para os as análises com microarranjo de DNA.

Com a continuidade do seqüenciamento do genoma B. elkanii foram adicionados 25.062 novas sequiências ao projeto. Os resultados finais da segunda montagem do genoma são as seguintes:

- 32.302 clones de shotgun;

- 768 pontas de cosmídeos;

- 3.795 contigs gerados na montagem;

- 1.155 seqüências de singlets;

- 5.370 ORFs, 54 RNAt; 2 RNAr;

- 5.1 milhões de nucleotídeos seqüenciados.

Os detalhes completos da última montagem parcial do genoma do B. elkanii, composta pelos novos clones, pode ser encontrado em http://lbmp.fcav.unesp.br/be587 


\subsection{Resultados da seleção de clones pelo $O C I 2$ aplicado na segunda montagem parcial do B. elkanii}

Baseado na segunda montagem parcial do genoma do B. elkanii, a ferramenta OCI 2 (Cantão et al., 2009) foi reprogramada para se comportar com as mesmas variáveis de seleção projetadas no código de programação do OC Identifier. Sendo assim, as regras de seleção de clones contendo genes únicos, foram divididas em quatro processos diferentes e mapeadas para as seguintes expressões algébricas:

- Select_CC_S cada seqüência amplificada pelos oligonucleotídeos universais forward e reverse estão localizados em diferentes contigs;

- Select_CC_D clones localizados nas seqüências dos mesmos contigs;

- Select_CS clones localizados nas seqüências dos singlets e contigs;

- Select_SS as seqüências dos clones localizados como singlets.

As expressões algébricas mapeadas de cada processo, assim como os resultados de cada processamento, são apresentadas a seguir.

- Processo de seleção de clones localizados nos mesmos contigs

- Expressão mapeada em álgebra de processos:

SET Select_CC_S $=\left(\frac{\circ}{\circ} \mathrm{SCBT}\right.$ (CC_S; Cro; ORF; 1; 0 ; Sho;

Null; Null) GO . DOW . END + $\frac{\circ}{\text { ! SCBT }}$ (CC_S; CrO; ORF;

1; 0; Sho; Null; Null) END);

- Resultado obtido após o processamento

\begin{tabular}{|l|c|}
\hline \multicolumn{1}{|c|}{ Rules Applied } & Clones Selected \\
\hline Selection Clones by Target & 6502 \\
\hline Finalization Process & 6502 \\
\hline
\end{tabular}

Tabela 1 - Número de clones selecionados após a execução do processo Select_CC_S 
- Processo de seleção de clones localizados em diferentes contigs

- Expressão mapeada em álgebra de processos:

SET Select_CC_D $=\left(\frac{\circ}{\mathrm{SCBT}}\right.$ (CC_D; Cro; ORF; $1 ; 0$; Sho; Null; Null) GO . DOW . END + o!SCBT (CC_D; CrO; ORF;

$1 ; 0$; Sho; Null; Null) END);

- Resultado obtido após o processamento

\begin{tabular}{|l|c|}
\hline \multicolumn{1}{|c|}{ Rules Applied } & Clones Selected \\
\hline Selection Clones by Target & 144 \\
\hline Finalization Process & 144 \\
\hline
\end{tabular}

Tabela 2 - Número de clones selecionados após a execução do processo Select_CC_D

- Processo de seleção de clones localizados em contigs e singlets

- Expressão mapeada em álgebra de processos:

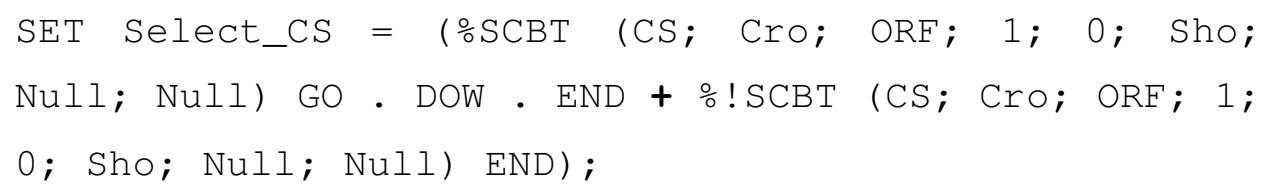

\begin{tabular}{|l|c|}
\hline \multicolumn{1}{|c|}{ Rules Applied } & Clones Selected \\
\hline Selection Clones by Target & 26 \\
\hline Finalization Process & 26 \\
\hline
\end{tabular}

Tabela 3 - Número de clones selecionados após a execução do processo Select_CS

- Processo de seleção de clones localizados como singlets

- Expressão mapeada em álgebra de processos:

SET Select_SS $=\left(\frac{\circ}{O} \mathrm{SCBT}\right.$ (SS; CrO; ORF; $1 ; 0$; Sho; Null; Null) GO . DOW . END + $\frac{\circ}{2}$ SCBT (SS; CrO; ORF; 1; 0; Sho; Null; Null) END);

\begin{tabular}{|l|c|}
\hline \multicolumn{1}{|c|}{ Rules Applied } & Clones Selected \\
\hline Selection Clones by Target & 5 \\
\hline Finalization Process & 5 \\
\hline
\end{tabular}

Tabela 4 - Número de clones selecionados após a execução do processo Select_SS 
Finalizadas as análises de todos os processos, 6.677 dos 32.302 clones de shotgun presentes foram selecionados contendo genes únicos. Na seleção processada pelo $O C I$ 2, foi observado que, além dos 2.654 clones selecionados na primeira seleção, 4.023 clones provenientes do novo seqüenciamento foram identificados como clones ótimos, isto é, clones contendo genes únicos.

O uso de clones contendo genes únicos também é possível aos projetos metagenômicos que trabalham com sequiências de cosmídeos. Assim, a mesma abordagem usada em genomas completos pode ser utilizada nos projetos de metagenomas, e os clones selecionados aplicados em experimentos biológicos sem a necessidade da síntese de oligonucleotídeos.

\subsection{Resultados da seleção de clones pelo $O C I 2$ aplicado no genoma completo de $X$. citri}

O OCI 2 foi testado para a seleção de clones ótimos em genomas completos. Para isso, o genoma completo e anotado da $X$. citri (Silva et al., 2002) foi analisado.

Nessa análise, os seguintes dados foram usados:

- DNA cromossomal com 5.1 milhões de bases;

- 4.313 ORFs, 54 RNAt; 6 seqüências de RNAr;

- 43.899 clones de shotgun;

- 2.358 pontas de cosmídeos.

Além do genoma cromossomal, a $X$. citri contém dois genomas plasmidiais, sendo eles:

- Plasmídeo XAC33

- $33 \mathrm{~Kb}$ de tamanho;

- 43 ORFs;

- 526 clones de shotgun;

- 3 pontas de cosmídeos.

- Plasmídeo XAC64

- $64 \mathrm{~Kb}$ de tamanho;

- 74 ORFs;

- 597 clones de shotgun;

- 28 pontas de cosmídeos. 
O processo de seleção foi elaborado para classificar como ótimos, os clones que atendem as seguintes condições:

- clones de shotgun do genoma cromossomal que contenham 1 ORF de tamanho superior a 400 bases;

- o clone poderá conter seqüência de outra ORF, mas de, no máximo, 10 nucleotídeos e nenhuma seqüência de RNAr ou RNAt;

- localizado externo à ORF e iniciar à distância superior ou igual a 15 bases da mesma.

O processo que satisfaz a condição de seleção de clones mencionada acima é mapeado para a seguinte expressão algébrica:

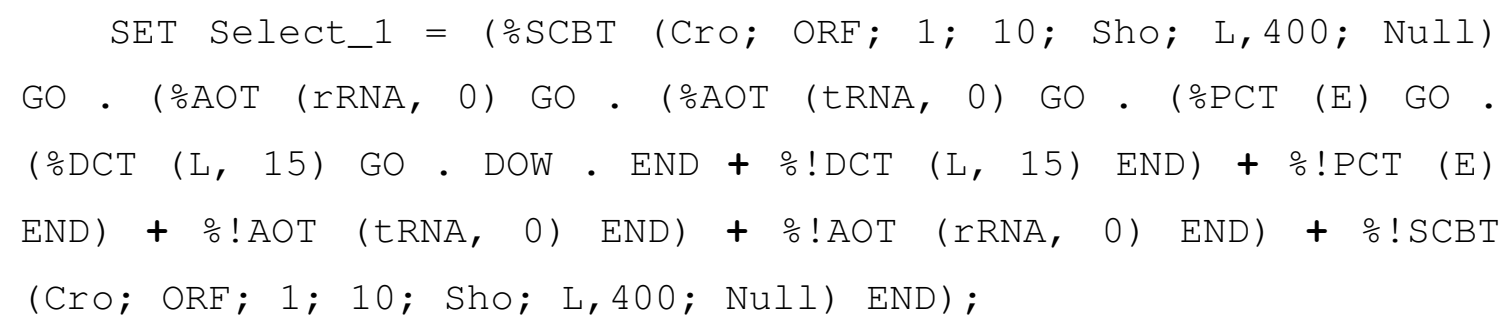

Após a definição do processo, o mesmo estará apto a ser executado pela página web da aplicação. As páginas que definem e executam os processos no genoma completo da $X$. citri podem ser acessados através do seguinte endereço http://tecnol86.fcav.unesp.br/Xantho

Com o processamento finalizado, a Tabela 5 mostra os resultados individuais de cada regra aplicada no processo Select_l, em conjunto com os números de clones ótimos, selecionados ao final da execução de cada regra:

\begin{tabular}{|l|c|}
\hline \multicolumn{1}{|c|}{ Rules Applied } & Clones Selected \\
\hline Selection Clones by Target & 6059 \\
\hline Analysis of Overlap Target (rRNA) & 6050 \\
\hline Analysis of Overlap Target (tRNA) & 5998 \\
\hline Position of Clone Outside Target & 459 \\
\hline Distance of Clone to Target $>=15$ & 411 \\
\hline Finalization Process & 411 \\
\hline
\end{tabular}

Tabela 5 - Número de clones selecionados após a execução de cada regra no genoma completo da $X$. citri

Dos 47,411 clones usados para análises, 6.059 contêm 1 ORF em suas seqüências e, portanto, foram selecionados pela primeira regra (SCBT - SelectClonesByTarget). A regra AOT (AnalysisOverlapTarget) excluiu 9 clones por apresentarem bases de RNAr e 52 clones 
por apresentarem bases de RNAt nas seqüências dos clones. Por sua vez, as regras seguintes PCT (PositionCloneTarget) e DCT (DistanceCloneTarget) foram executadas e selecionaram 459 e 411 clones, respectivamente. Assim, após avaliar todas as regras de seleção, o processo Select_l finalizou sua execução com 411 clones ótimos selecionados.

\subsection{Resultados da seleção de clones pelo $O C I 2$ aplicado em projeto metagenômico}

O OCI 2 também permite a seleção de clones ótimos em dados de projetos metagenômicos. Nessa perspectiva, o OCI 2 foi usado para selecionar clones contendo genes de interesse no projeto metagenômico, cujo objetivo é localizar genes de biossíntese que possam ser usados como possíveis antibióticos. Para essa análise, foram usados os dados do seqüenciamento completo do cosmídeo B7P37 (Schuch et al., 2008).

Inicialmente, OCI 2 selecionou clones contendo genes de interesse biotecnológicos para serem usados em vetores de expressão. Dessa forma, as buscas aos clones ótimos foram realizadas no cosmídeo B7P37 sob as seguintes condições:

- 1.131 clones seqüenciados;

- $30 \mathrm{~Kb}$ de tamanho;

- 15 ORFs identificadas.

As 15 ORFs identificadas e anotadas no cosmídeo B7P37, junto com suas funções gênicas são apresentadas a seguir.

\begin{tabular}{|c|l|}
\hline \multicolumn{1}{|c|}{ Ids } & \multicolumn{1}{|c|}{ Function } \\
\hline \hline 1 & polyketide synthases (PKSs) \\
\hline 2 & Efflux transporter, RND family, MFP subunit \\
\hline \hline 3 & ABC transporter, ATP-binding protein \\
\hline \hline 4 & Dehydrogenases/Redutase \\
\hline 5 & Aspartyl/Asparaginyl beta-hydroxylase \\
\hline 6 & 9 acyl-lipid fatty acid desaturase \\
\hline 7 & Fatty acid desaturase \\
\hline \hline 8 & Carbohydrate kinase \\
\hline \hline 10 & Uncharacterized Protein Conserved \\
\hline \hline 11 & Twin-arginine translocation pathway signal sequence \\
\hline \hline
\end{tabular}




\begin{tabular}{|c|l|}
\hline 12 & Putative ABC-type uncharacterized transport system \\
\hline \hline 13 & Monooxygenase, FAD-binding \\
\hline \hline 14 & Aldo/keto reductase \\
\hline \hline 15 & Hypothetical protein \\
\hline
\end{tabular}

Tabela 6 - Códigos de identificação e funções das ORFs identificadas e anotadas do Cosmídeo B7P37

A seguir, mostra se o processo de seleção elaborado para satisfazer a seguinte pergunta biológica:

- selecionar clones que representem a ORF identificada pelo Id 3 (função, $A B C$ transporter, ATP-binding protein);

- clones localizados externos à ORF;

- iniciar a uma distância mínima de 30 bases da ORF de interesse.

Definidas as regras de seleção, o processo que controla a execução do fluxo do sistema é então criado com o nome Select_ORF_3 e mapeado para a seguinte expressão algébrica:

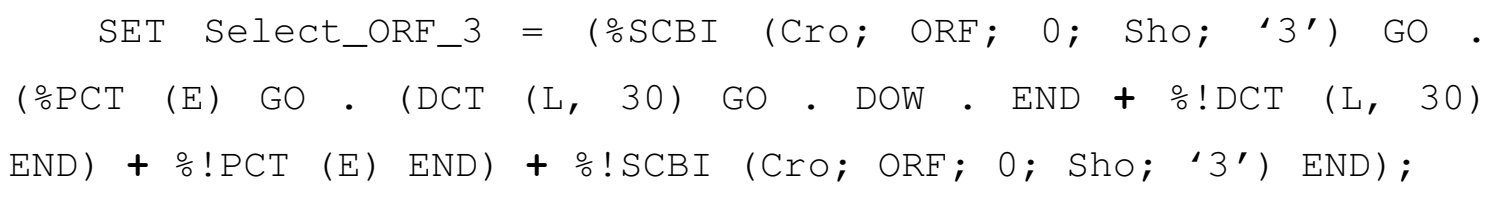

Com o processo de seleção criado, as análises são então executadas pela página do projeto localizado em http://tecnol86.fcav.unesp.br/B7P37. Após o processamento das regras, os resultados são apresentados a seguir:

\begin{tabular}{|l|c|}
\hline \multicolumn{1}{|c|}{ Rules Applied } & Clones Selected \\
\hline Seleção de Clones por Ids & 8 \\
\hline Position of Clone Outside Target & 3 \\
\hline Distance of Clone to Target $>=30$ & 2 \\
\hline Finalization Process & 2 \\
\hline
\end{tabular}

Tabela 7 - Número de clones selecionados após a execução de cada regra do processo Select_ORF_3 no projeto de metagenoma

Nessa seleção, os clones ótimos são caracterizados pela presença do gene identificado pelo Id 3. Inicialmente, a execução da regra SCBI (SelectClonesById) identificou 8 clones que contêm a sequiência do gene de interesse. A seguir, com a aplicação da regra PCT 
(PositionCloneTarget), 3 clones dos 8 inicialmente selecionados contêm as ORFs internas às suas seqüências. Por fim, com a análise da regra DCT (DistanceCloneTarget), 1 clone foi retirado por iniciar a distância inferior as 30 bases da ORF. Ao final do processo Select_ORF_3, somente 2 clones foram selecionados como ótimos para representar a ORF identificada pelo Id 3 .

Sendo assim, os 2 clones identificados como ótimos para este projeto contém o gene de interesse, e suas seqüências podem ser amplificadas e utilizadas no experimento sugerido.

\subsection{Conclusão}

O uso da álgebra de processos no mapeamento das regras do OCI 2 possibilitou maior poder de expressividade e ganho de flexibilidade no controle do fluxo do sistema. Por meio de um arcabouço algébrico, todas as regras foram mapeadas em expressões da álgebra de processos e as buscas aos clones ótimos ampliadas a novos projetos de pesquisas. O uso da álgebra garantiu consistência no sistema, uma vez que as alterações passaram a ocorrer de forma dinâmica e externa ao programa, por meio da geração automática de código. Dessa forma, os pesquisadores passaram a criar e alterar suas próprias regras de seleção, independentemente de programadores.

Por meio da abordagem algébrica, foi possível estender as buscas aos clones ótimos para diferentes projetos e organismos, de modo mais rápido e seguro que as formas tradicionais. Adicionalmente, a abordagem algébrica assegurou a reutilização dos mesmos códigos a todas as regras dos projetos, excluiu redundâncias no código do aplicativo e proporcionou aumento na flexibilidade e eficiência do sistema. Com as regras de seleção mapeadas em expressões algébricas, a ferramenta selecionou clones em projetos de genoma procarioto completo e parcialmente seqüenciado. Também foi possível a seleção de clones em projeto metagenômico.

Porém, o processo de mapear as regras em expressões algébricas ainda encontra limitações na implementação da abordagem algébrica. Esse processo exige grandes esforços por parte do desenvolvedor, uma vez que é necessário criar uma interface que compila todos os dados e os convertem nas expressões em NPDL. Tais limitações são poucas se comparadas ao ganho de flexibilidade que a abordagem algébrica oferece ao controle no comportamento do fluxo do sistema, assim como, na consistência durante a execução dos processos do sistema. 


\subsection{Trabalhos futuros}

O seqüenciamento do genoma do $B$. elkanii será continuado com a adição de milhares de seqüências produzidas pela nova geração de seqüenciadores automáticos. Com as novas seqüências, em conjunto com as disponíveis no projeto, espera-se alcançar o completo seqüenciamento do genoma. Uma vez o genoma finalizado, o OCI 2 será empregado na seleção dos clones de interesse para compor um microarranjo de genes conhecidos para os futuros projetos de transcriptomas no Laboratório de Bioquímica de Microorganismos e Plantas (LBMP).

Além das análises do genoma do B. elkanii, o OCI 2 continuará a ser empregado na seleção de clones com genes de interesses biotecnológicos nos diversos projetos metagenômicos em desenvolvimento no LBMP.

Do ponto de vista computacional, a melhoria da interface com usuário, a definição da ordem da execução das regras pelo usuário, o armazenamento histórico e controle de versões dos workflows são desafios a serem assumidos como futuros trabalhos. 


\section{Referências Bibliográficas}

Aalst, W.M.P. van der, Hofstede, A.H.M. ter, Kiepuszewski, B., Barros, A.P. (2003) Workflow Patterns. Distributed and Parallel Databases, v. 14, n. 1, p. 5-51.

Almeida, L.G., Paixao, R., Souza, R.C., Costa, G.C., Barrientos, F.J., Santos, M.T., Almeida, D.F., Vasconcelos, A.T. (2004). A System for Automated Bacterial Integrated Annotation-SABIA. Bioinformatics, 20: 2832-3.

Bergstra, J.A., Ponse, A., Smolka, S.A. (2001). Handbook of process algebra. Amsterdã:

Elsevier Science Inc.

Braghetto, K.R., Ferreira, J.E., Pu, C. (2007). Using Control-Flow Patterns for Specifying Business Processes in Cooperative Environments. In: The 22nd Annual ACM Symposium on Applied Computing, Seoul. In: 22nd Annual ACM Symposium on Applied Computing, 2: 1234-41.

Cantão, M.E., Araújo, L.V., Lemos, E.G.M., Ferreira, J. E. (2009). Optimal Clone Identifier based on Dynamic Rules and Process Algebra. In: International Conference on Bioinformatics, Computational Biology, Genomics and Chemoinformatics. International Society for Research in Science and Technology, p. 92-99.

Cantão, M.E., Ferreia, J.E., Lemos, E.G.M. (2007). Optimal Clones Identifier for Genomic Shotgun Libraries: “OC Identifier tool”. Genet. Mol. Res. 6: 743-55.

Carraro, M.D., Kitajima, J.P. (2002). Seqüenciamento e Bioinformática de Genomas Bacterianos. Biotecnologia Ciência \& Desenvolvimento. 28: 16-20.

Cattley, S., Arthur J.W. (2007). BioManager: the use of a bioinformatics web application as a teaching tool in undergraduate bioinformatics training. Briefings in Bioinformatics. $8: 457-465$.

Chaisson, M.J., Pevzner P.A. (2008). Short read fragment assembly of bacterial genomes. Genome Res. 18: 324-30.

Dohm, J.C., Lottaz, C., Borodina, T., Himmelbauer, H. (2007). SHARCGS, a fast and highly accurate short-read assembly algorithm for de novo genomic sequencing. Genome Res. 11:1697-706.

Durham, A.M., Kashiwabara, A.Y., Matsunaga, F.T., Ahagon, P.H., Rainone, F., Varuzza, L., Gruber, A. (2005). EGene: a configurable pipeline generation system for automated sequence analysis. Bioinformatics 12: 2812-3. 
Edwards-Ingram, L.C., Gent, M.E., Hoyle, D.C., Hayes, A., Stateva, L.I., Oliver, S.G. (2004). Comparative Genomic Hybridization provides new insights into the molecular taxonomy of the Saccharonyces sensu strictu complex. Genome Research, 14: 1043-51.

Ferreira, J.E., Takai, O.K., Braghetto, K.R., Pu C. (2006). Large Scale Order Processing through Navigation Plan Concept. In: IEEE International Conference on Services Computing, Chicago, IL, USA.

Fleischmann, R.D., Adams, M.D., White, O., Clayton, R.A., Kirkness, E.F., Kerlavage, A.R., Bult, C.J., Tomb, J.F., Dougherty, B.A., Merrick, J.M., McKenney, K., Sutton, G., Fitzhugh, W., Fields, C., Gocyne, J.D., Scott, J., Shirley, R., Liu, LiIng., Glodek, A., Kelley, J.M., Weidman, J.F., Phillips, C.A., Spriggs, T., Hedblom, E., Cotton, M.D., Utterback, T.R., Hanna, M.C., Nguyen, D.T., Saudek, D.M., Brandon, R.C., Fine, L.D., Fritchman, J.L., Fuhrmann, J.L., Geoghagen, N.S.M., Gnehm, C.L., McDonald, L.A., Small, K.V., Fraser, C.M., Smith, H.O., Venter, J.C. (1995). Whole-genome random sequencing and assembly of Haemophilus influenzae Rd. Science 269: 496-512.

Fokkink , W.J. (2000). Introduction to Process Algebra: Texts in Theoretical Computer Science. Berlin: Springer-Verlag New York, Inc., p. 163.

Fujita, A; Massirer, K. B; Durham, A. M; Ferreira, C. E; Sogayar, M. C. (2005). The GATO gene annotation tool for research laboratories. Braz. j. med. biol. Res. 38:1571-1574.

Giuntini, E., Mengoni, A., De Filippo C., Cavalieri, D., Aubin-Horth, N., Landry, C.R., Becker, A., Bazzicalupo, M. (2005). Large-scale genetic variation of the symbiosisrequired megaplasmid pSymA revealed by comparative genomic analysis of Sinorhizobium meliloti natural strains. BMC Genomics. 6: 158.

Goldberg S.M., Johnson J., Busam, D., Feldblyum, T., Ferriera, S., Friedman, R., Halpern, A., Khouri, H., Kravitz, S.A., Lauro, F.M., Li, K., Rogers, Y.H., Strausberg, R., Sutton, G., Tallon, L., Thomas, T., Venter, E., Frazier, M., Venter, J.C. (2006). A Sanger/pyrosequencing hybrid approach for the generation of highquality draft assemblies of marine microbial genomes. Proc Natl Acad Sci. 103: 112405.

Harkins, T., Jarvie, T. (2007) Metagenomics analysis using the genome sequencer FLX system. Nat Methods 4: application notes iii-v.

Hauser, F.A., Lindemann, S., Vuilleumier, A., Patrignani, R., Schlapbach, H.M., Fischer, Hennecke, H. (2006). Design and validation of a partial-genome microarray for transcriptional profiling of the Bradyrhizobium japonicum symbiotic gene region. Mol. Genet. Genomics. 275: 55-67. 
Hoare, C.A.R. (1978). Communicating sequential processes. Communications of the ACM, 21: 666-77.

Hollinsworth, D. (1995). The Workflow Reference Model. Winchester: Workflow Management Coalition, p 55. (Relatório técnico, WFMC-TC00-1003).

Huang, X., Madan, A. (1999) CAP3: A DNA Sequence Assembly Program. Genome Res. 9: 868-877.

Kim, J.S., Lim, H.K., Lee, M.H., Park, J.H., Hwang, E.C., Moon, B.J., Lee, S.W. (2009). Production of porphyrin intermediates in Escherichia coli carrying soil metagenomic genes. FEMS Microbiol Lett. 295: 42-9.

Koide, T., Zaini, P.A., Moreira, L.M., Vencio, R.Z., Matsukuma, A.Y., Durham, A.M., Teixeira, D.C., El-Dorry, H., Monteiro, P.B., da Silva, A.C., Verjovski-Almeida, S., da Silva, A.M., Gomes, S.L. (2004). DNA Microarray-Based Genome Comparison of a Pathogenic and a Nonpathogenic Strain of Xylella fastidiosa Delineates Genes Important for Bacterial Virulence: J Bacteriol. 186: 5442-49.

Letowski, J., Brousseau, R., Masson, L. (2003). DNA microarray applications in environmental microbiology. Analytical Letters, 36: 3165-84.

Li, L.-H., Li, J.-C., Lin, C.-Y., Chen, C.-Y., Tsai, S.-F. (2004). Genomic shotgun array: a procedure linking large-scale DNA sequencing with regional transcript mapping. Nucleic Acids Res. 32:e27.

Ludäscher, B., Altintas, I., Berkley, C., Higgins, D., Jaeger-Frank, E., Jones, M., Lee, E., Tao, J., Zhao, Y. (2005). Scientific Workflow Management and the Kepler System. Concurrency and Computation: Practice \& Experience, Special Issue on Scientific Workflows, to appear, 2005. http://kepler-project.org

MAPA (Ministério da Agricultura, Pecuária e Abastecimento). (2006). Disponível em: http://extranet.agricultura.gov.br

Marcondes, J., Cantão, M.E., Alves, L.M.C., Lemos, E.G.M. (2008). Transcriptional profile of Bradyrhizobium elkanii Semia 587 in symbiosis with soybean (Glycine max L. Merril) analyzed by DNA microarray. In: Felix D. Dakota; Samson B. M. Chimphango; Alex J. Valentine; Claudine Elmerich; William E. Newton. (Org). Current Plant Science and Biotechnology in Agriculture. Springer, 42: 299-300.

Meyer, F., Goesmann, A., McHardy, A.C., Bartels, D., Bekel, T., Clausen, J., Kalinowski, J., Linke, B., Rupp, O., Giegerich, R., Puhler, A. (2003). GenDB-an open source genome annotation system for prokaryote genomes. Nucleic Acids Res. 31: 2187-95. 
Meyer, F., Paarmann, D., D'Souza, M., Olson, R., Glass, E.M., Kubal, M., Paczian T., Rodriguez, A., Stevens, R., Wilke, A., Wilkening, J., Edwards, R. A. (2008). The Metagenomics RAST server - A public resource for the automatic phylogenetic and functional analysis of metagenomes. BMC Bioinformatics, 9:386.

Milner, R.A. (1982). Calculus of Communicating Systems. Secaucus: Springer-Verlag New York, Inc., p. 260.

Moreira, L.M. (2006). Análise estrutural e funcional do genoma de Xanthomonas axonopodis pv. citri. Tese de Doutorado. Instituto de Química, Universidade de São Paulo, USP.

Murata, T. (1989). Petri Nets: Properties, Analysis and Applications. Proceedings of The IEEE, 77: 541-80.

Nickerson, D.A., Tobe, V.O., Taylor, S.L. (1997). PolyPhred: automating the detection and genotyping of single nucleotide substitutions using fluorescence-based resequencing. Nucleic Acids Res. 25: 2745-51.

Pathak, G.P., Ehrenreich A., Losi, A., Streit, W.R., Gärtner, W. (2009). Novel blue lightsensitive proteins from a metagenomic approach. Environmental Microbiology, 9: 238899.

Pereira, R.M. (2007). Filogenia de rizóbios utilizando comparação de genomas por hibridização através de Microarray. Tese Doutorado. Universidade Estadual Paulista, Faculdade de Ciências Agrárias e Veterinárias, UNESP, Jaboticabal.

Pierce, A.B. (2004). Genética: Um Enfoque Conceitual. 5a Edição. Rio de Janeiro: Editora Guanabara Koogan.

Pinkel, D., Albertson, D.G. (2005). Comparative Genomic Hybridization. (2005). Annu. Rev. Genomics Hum. Genet. 6: 331-54.

Porwollik, S., Wong, R., McClelland, M. (2002). Evolutionary genomics of Salmonella: Gene acquisitions revealed by microarray analysis. Proceedings of the National Academy of Sciences, 99: 8956-61.

Prosdocimi, F., Cerqueira, G.C., Binneck, E., Silva, A.F., Reis, A.N., Junqueira, A.C.M., Santos A.C.F., Nhani Junior, A., Wust C.I., Camargo Filho, F, Kessedjian, J.L., Petretski, J. H., Camargo L.P., Ferreira, R.G.M., Lima, R. P., Pereira, R.M., Jardim, S., Sampaio, V.S., Folgueras-flatschart, A.V. (2002). Bioinformática: manual do usuário. Biotecnologia ciência \& desenvolvimento. 29: 18-33.

Overbeek, R., Larsen, N., Walunas, T., D'Souza, M., Pusch, G., Selkov, E. Jr, Liolios, K., Joukov, V., Kaznadzey, D., Anderson, I., Bhattacharyya, A., Burd, H., Gardner, W., Hanke, P., Kapatral, V., Mikhailova, N., Vasieva, O., Osterman, A., Vonstein, 
V., Fonstein, M., Ivanova, N., Kyrpides, N. (2003). The ERGO ${ }^{\mathrm{TM}}$ genome analysis and discovery system. Nucleic Acids Res 31: 164-71.

Roach, J. C., Thorsson, V., Siegel, A.F. (2000). Parking strategies for genome sequencing. Genome research. 10: 1020-30.

Ronaghi, M. (2001). Pyrosequencing sheds light on DNA sequencing. Genome Res. 11: 3-11.

Rosa, G.J.M, Rocha, L.B., Furlan, L.R. (2007). Estudos de expressão gênica utilizando-se microarrays: delineamento, análise, e aplicações na pesquisa zootécnica. $R$. Bras. Zootec. 36: 185-209.

Rutherford, K., Parkhill, J., Crook, J., Horsnell, T., Rice, P., Rajandream, M.A., Barrell, B. (2000). Artemis: sequence visualization and annotation. Bioinformatics 16: 944-5.

Sanger, F., Nicklen, S., Coulson, A.R. (1977). DNA sequencing with chain-terminating inhibitors. Proc Natl Acad Sci USA 74: 5463-7.

Schuch, V., Alves, L.M.C., Lemos, M.V., Lemos E.G.M. (2008) Discovery of genes related to antibiotic biosynthesis into a metagenomic library. In: 12th International Symposium on Microbial Ecology, Cairns, Australia, p.17-22.

Scott, K.P., Martin, J.C., Campbell, G., Mayer, C., Flint, H.J. (2006). Whole-genome transcription profiling reveals genes up-regulated by growth on fucose in the human gut bacterium Roseburia inulinivorans. Journal of Bacteriology. 188: 4340-9.

Shah, S.P., He, D.Y., Sawkins, J.N., Druce, J.C., Quon, G., Lett, D., Zheng, G.X., Xu, T., Ouellette, B.F. (2004). Pegasys: software for executing and integrating analyses of biological sequences. BMC Bioinformatics 5:40.

Silva, A.C., Ferro, J.A., Reinach, F.C., Farah, C.S., Furlan, L.R., Quaggio, R.B., Monteiro-Vitorello, C.B., Van Sluys, M.A., Almeida, N.F., Alves, L.M., do Amaral, A.M., Bertolini, M.C., Camargo, L.E., Camarotte, G., Cannavan, F., Cardozo, J., Chambergo, F., Ciapina, L.P., Cicarelli, R.M., Coutinho, L.L., Cursino-Santos, J.R., El-Dorry, H., Faria, J.B., Ferreira, A.J., Ferreira, R.C., Ferro, M.I., Formighieri, E.F., Franco, M.C., Greggio, C.C., Gruber, A., Katsuyama, A.M., Kishi, L.T., Leite, R.P., Lemos, E.G., Lemos, M.V., Locali, E.C., Machado, M.A., Madeira, A.M., Martinez-Rossi, N.M., Martins, E.C., Meidanis, J., Menck, C.F., Miyaki, C.Y., Moon, D.H., Moreira, L.M., Novo, M.T., Okura, V.K., Oliveira, M.C., Oliveira, V.R., Pereira, H.A., Rossi, A., Sena, J.A., Silva, C., de Souza, R.F., Spinola, L.A., Takita, M.A., Tamura, R.E., Teixeira, E.C., Tezza, R.I., Trindade dos Santos. M., Truffi, D., Tsai, S.M., White, F.F., Setubal, J.C., Kitajima, J.P. 
(2002). Comparison of the genomes of two Xanthomonas pathogens with differint host specificities. Nature 417: 459-63.

Stothard, P., Wishart, D.S. (2005). Circular genome visualization and exploration using CGView. Bioinformatics 21: 537-39.

Sutton, G.G., White, O., Adams, M.D., Kerlavage, A.R. (1995). TIGR Assembler: A new tool for assembling large shotgun sequencing projects. Genome Science and Technology, 1: 9-19.

Voet, D., Voet, J.G., Pratt, C.W. (2000). Fundamentos de Bioquímica. Cap. 3, p. 54-5. Artmed Editora.

Watanabe, T., Murata, Y., Oka, S., Iwahashi, H. (2004). A new approach to species determination for yeast strains: DNA microarray-based comparative genomic hybridization using a yeast DNA microarray with 6000 genes. Yeast. 21: 351-65.

Yeo, R.W., Wang, T., Bedzyk, L., Croker, K.M. (2001) Applications of DNA microarrays in microbial systems. Journal of Microbiological Methods, 47: 257-72. 